\title{
La fortaleza medieval de Isso (Albacete) y su territorio
}

\author{
The medieval fortress of Isso (Albacete) and its territory
}

\author{
Julio Navarro Palazón a, Pedro Jiménez Castillo b, Francisco Javier López Martínez c \\ Sara Peñalver Martín ${ }^{d}$, Antonio Reyes Martínez ${ }^{\mathrm{e}}$, Luis José García-Pulidof \\ ${ }^{a}$ Laboratorio de Arqueología y Arquitectura de la Ciudad - Escuela de Estudios Árabes - Consejo Superior de \\ Investigaciones Científicas, Granada, Spain, julionavarro@eea.csic.es

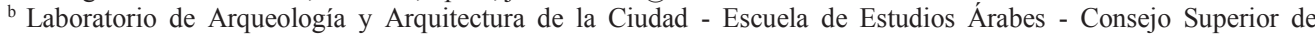 \\ Investigaciones Científicas, Granada, Spain, pedro@eea.csic.es \\ ${ }^{\mathrm{c}}$ Universidad Católica de Murcia, Murcia, Spain, fjlopez@ucam.edu \\ ${ }^{\mathrm{d}}$ Architect, Granada, Spain, s.penalver.martin@gmail.com \\ eArchaeologist, Granada, Spain, antoniodelosreyes@hotmail.com \\ ${ }^{\mathrm{f}}$ Laboratorio de Arqueología y Arquitectura de la Ciudad - Escuela de Estudios Árabes - Consejo Superior de \\ Investigaciones Científicas, Granada / Departamento de Arte y Arquitectura - Universidad de Málaga, Málaga, Spain, \\ luis.garcia@uma.es
}

\begin{abstract}
This paper presents some of the information obtained during the archaeological surveys carried out in 2019 in the state fortress known as Torre de Isso, located in the municipality of Hellín (Albacete). These fieldworks have attempted to answer some questions related to the historical interpretation of the preserved monumental remains, specifically two large towers and some walls from the second half of the thirteenth or fourteenth century. The initial study and graphical documentation were carried out to obtain the data needed to draft a conservation project in line with current scientific criteria.

Extending the investigation to the whole neighbourhood of houses that surrounds the towers resulted in the discovery of a quadrangular fortress of $44 \times 42 \mathrm{~m}$, which incorporates the towers and in which different construction phases have been identified, certainly prior to and subsequent to the Christian conquest. The remains found were reused in the load-bearing walls of some of the houses. Beside the fortress, we extended the study to the entire village of Isso, in order to find out if the medieval castle had an annexed relevant village. Finally, the surveys expanded throughout the entire territory of Isso, with the desire to know if its characteristic dispersed settlement, made up of small farmhouses, and its traditional irrigation system, have a medieval origin.

This multidisciplinary research project has allowed us to obtain extensive data and produce significant information, although it should be noted that many issues and some of the interpretations offered in this article are still hypothetical. Therefore, only future development of additional archeological and historical works will make it possible to tackle those questions that remain to be answered.
\end{abstract}

Keywords: Isso, Hellín, fortress, formwork, Middle Ages, medieval settlements.

\section{Introducción}

En este trabajo se dan a conocer los resultados obtenidos en la primera campaña de investigación arqueológica realizada en el territorio y en la fortaleza de Isso (Hellín, Albacete), dirigida por el Laboratorio de Arqueología y Arquitectura de la Ciudad (LAAC), adscrito a la Escue- 
la de Estudios Árabes (CSIC), durante los meses de septiembre - diciembre de 2019 (Fig. 1). El proyecto ha sido promovido y financiado por el Ayuntamiento de Hellín y ha contado con una subvención de la Junta de Castilla La Mancha ${ }^{1}$. Su objetivo último era obtener el necesario conocimiento histórico y arquitectónico que permitiera afrontar, con las mayores garantías, la restauración de la fortaleza allí existente, cuyo estado de conservación es muy deficiente y cercano a la ruina.

Tradicionalmente, los restos monumentales de este castillo han sido denominados Torre de Isso debido a que, en una fecha bastante tardía, las dos torres existentes quedaron unidas mediante la construcción de un muro de fachada. Esta y otras transformaciones han ido destruyendo y ocultando progresivamente algunas partes de este recinto fortificado, por lo que ya no era percibido como tal por la población local cuando quedó establecida esta denominación. Actualmente, ambas torres forman parte de un gran caserón arruinado, situado en el barrio que hemos dado en llamar de la fortaleza (Fig. 4).

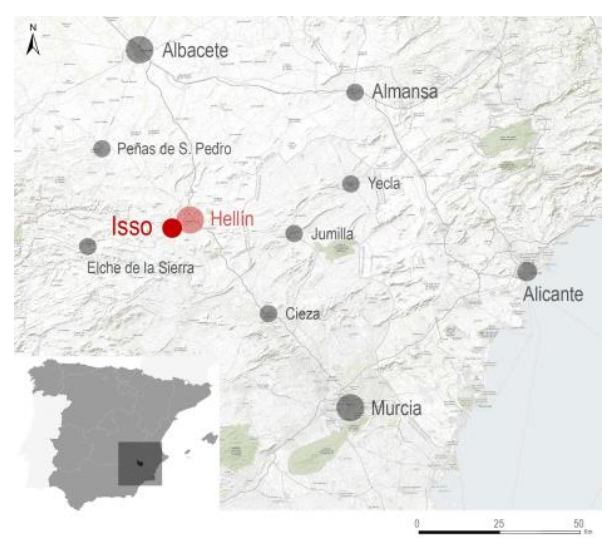

Fig 1. Situación de Isso (Hellín). Fuentes base cartográfica: Esri, DeLorme, USGS, NPS. (C) OpenStreetMap contributors, GIS User Community.

Los trabajos realizados se han centrado en los siguientes aspectos:

Recopilación de fuentes documentales e iconográficas. Se ha llevado a cabo una profunda búsqueda bibliográfica y de archivo, con espe- cial atención a todos aquellos estudios y documentos que aportan datos sobre el territorio de Isso ${ }^{2}$. También se ha hecho una amplia labor de recopilación de fotografías, planimetrías y cartografía antiguas.

Prospección arqueológica. En el término de Isso, más concretamente en el área de influencia directa de la fortaleza, se ha desarrollado una intensa labor de localización e inventariado de los restos arqueológicos y etnográficos existentes, prestando especial atención al poblamiento y a las infraestructuras hidráulicas (Fig. 2). Con el objetivo de conocer mejor el asentamiento medieval y de contextualizar adecuadamente la fortaleza, se amplió la exploración, de manera menos intensiva, a todo el término municipal de Hellín, alcanzando algunos puntos de los territorios limítrofes, como Tobarra y Ontur (Fig. 3).

Análisis arquitectónico. En un primer momento, se realizó un estudio exhaustivo de las dos torres medievales que se conservan en pie, así como del edifício de época moderna en el que quedaron englobadas.

Sin embargo, ante la existencia de indicios de que las torres podrían formar parte de un recinto fortificado de mayores dimensiones que quedó fagocitado por las numerosas viviendas que lo ocuparon, se extendió el estudio a todo el barrio, con el objetivo de localizar y analizar la presencia de otros restos (Fig. 4). Para ello, se ha realizado un levantamiento fotogramétrico y planimétrico del conjunto, así como de cada una de las casas que lo componen. ${ }^{3}$

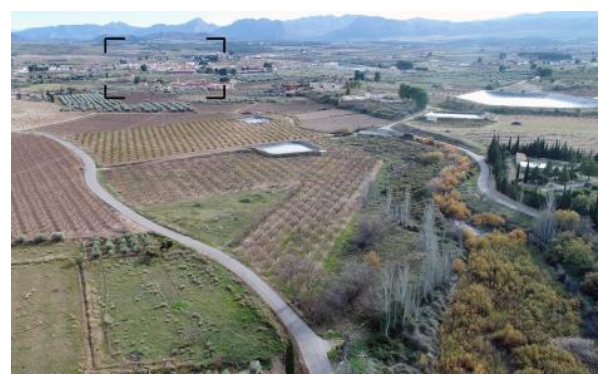

Fig. 2. Isso. Vista del territorio de Isso desde la Fuente, situada a la derecha de la imagen. El recuadro señala el emplazamiento de la fortaleza y de su caserío. Al fondo aparece la Sierra de los Donceles. 


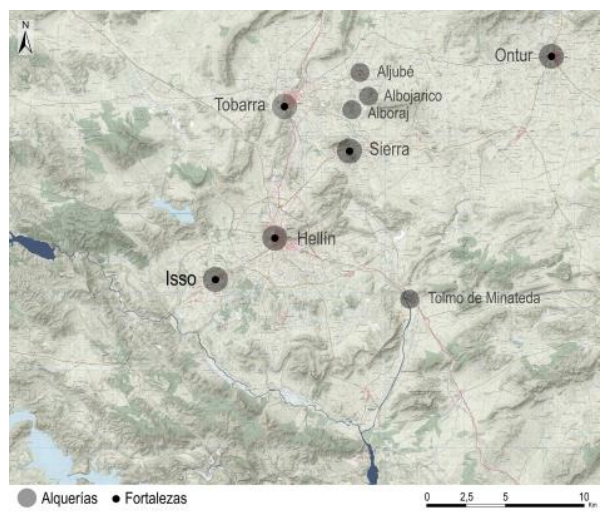

Fig. 3. Entorno de Isso, con las principales fortalezas y alquerías. Base cartográfica: Mapa Topográfico Nacional a escala 1:25000.

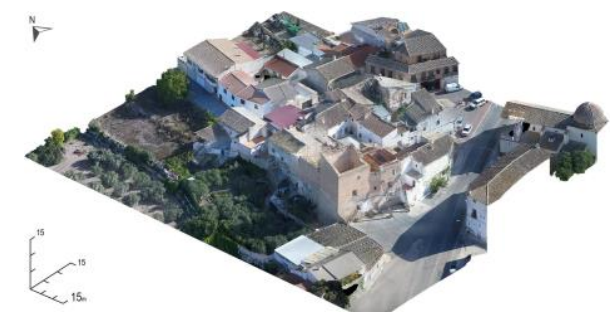

Fig 4. Isso. Vista axonométrica del núcleo de casas construido en la antigua fortaleza de Isso, obtenida a partir del modelo fotogramétrico del conjunto.

\section{El topónimo de Isso}

El origen y significado del topónimo Isso es incierto; sin embargo, queda constancia de que ha ido evolucionando a lo largo del tiempo, presentando diferentes grafías.

Aunque no hay evidencias seguras, algunos autores lo han identificado con "Asso", localidad romana situada al oriente de Abula (Abla, prov. de Almería), según aparece en Las Tablas de Ptolomeo, si bien otros ubican esta localidad en las proximidades de Caravaca (Murcia). Según Vitrubio, el término "Asso" era un verbo latino que significaba hacer tablados, aunque el canónigo Juan Lozano era más partidario, sin mucho fundamento, de una etimología griega (Lozano, 1794, pp. 34-36).

Pocklington considera que tiene un origen latino: "Establecida la existencia de la variante
Asso de Auzo, podemos partir de esta misma raíz para explicar el nombre de Isso, documentado como "Hyso" en 1243 y 1252. En este caso la A tónica se convertiría en I durante su paso por el árabe, debido al proceso de la "imela de segundo grado", responsable precisamente de la transformación de la A de Falyān en la I de Hellín" (Pocklington, 2010, pp. 119-120).

En el siguiente listado se muestran las diferentes grafías con las que aparece este topónimo en diversos documentos a lo largo del tiempo, hasta adquirir su forma actual:

HISO El infante don Alfonso concede Alcantarilla 1251 y otras propiedades al maestre de Alcántara.

HYSO La Orden de Calatrava da su recibo a la 1252 reina Dña. Juana, de 26 privilegios que eran de ella y que la Orden tenía en custodia.

YSO

Los milagros romanzados de Santo Domin1283 go de Silos de Pero Marín.

ISSO Fernando IV otorga diversos privilegios y 1305 franquezas a los moradores de Hellín e Isso.

YSO Los Reyes Católicos confirman a Hellín el 1476 privilegio de Valladolid del 12-IV-1409.

YSO Provisión de Carlos I y su madre, dirigida al 1527 gobernador del Marquesado de Villena.

YSO

Relaciones topográficas de Felipe II.

1576

YSO

Codicilo de Francisco de Villena y Medrano.

1637

YSO
Testamento de Jerónima Ortín. 


\section{YSO Catastro de Ensenada. \\ 1749 \\ ISO Correo de Nipho. \\ 1769 \\ ISO Atlante Español. \\ 1778 \\ YSSO Relaciones Geográfico-Históricas de Alba- 1786-9 cete. Tomás López.}

ISSO Bastitania y Contestania del Reyno de Mur1794 cia. Juan Lozano.

ISO Diccionario de Sebastián Miñano.

1826

ISSO Diccionario de Madoz.

1847

Isso es también un apellido toponímico utilizado por numerosos judíos. Las familias de Isso expulsadas en 1492 buscaron refugio en Marruecos, lo que explica que finalmente este apellido se considere propio de los judíos marroquíes (Laredo, 1978, pp. 646-647). Actualmente, en España este apellido es minoritario y se escribe tanto con una "S" (Iso) como con dos (Isso).

\section{Delimitación del término de Isso}

Isso es una de las 12 pedanías que en la actualidad forman parte del municipio de Hellín (Albacete), perteneciente a la comunidad autónoma de Castilla-La Mancha. A continuación se las menciona por orden alfabético: Agra, Agramón, Cañada de Agra, Cancarix, Isso, La Horca, Las Minas, Minateda, Mingogil, Nava de Campana, Rincón del Moro y Torre Uchea.

Como veremos más adelante, Isso constituyó un señorío individualizado hasta su incorporación a la localidad de Hellín, remontándose su autonomía, muy probablemente, a época andalusí. A pesar de ello, no tenemos constancia de cuáles fueron los límites precisos de su territorio castral. No obstante, creemos que pudieron estar marcados, a grandes rasgos, por los accidentes topográficos que describimos a continuación: al norte, los caminos de Fuente y de Liétor; al sur, los montes de El Casarejo, Aguas Calientes, Alto de las Bragas y Cañada del Judío; al este, la rambla del Pepino, que es la que separa Isso de Hellín; al oeste, las Lomas de Amado, Cerro de Ruiz Sánchez, Collado de las Cuevas, Porrón de Liétor, Peña Lavada y Cabezo de la Peña del Agua, hasta alcanzar el río Mundo.

El límite oriental y una parte del meridional coincidirían con el término municipal de $\mathrm{He}$ llín, según aparece en el Catastro de Ensenada, de mediados del siglo XVIII: "[...] el Poniente lindando con el término de Lietor de allí al Cerro que llaman de Ruiz Sánchez, de allí a la Sierra de Peñalavada, de allí a la Cañada del Judío y lo divide el término de Socovos".

La divisoria con Liétor está fijada, como mínimo, desde 1246; esta era, a su vez, frontera entre el señorío de Villena (correspondiente al territorio de Isso) y los territorios de la Orden de Santiago (Liétor), según aparece en el documento de concesión del Fuero de Cuenca al Concejo de Segura de la Sierra en el que le señalan sus términos: "E sobre esto, damos e otorgamos términos de partidos a Segura: [...] e como parte Lietor con Fellín, e con Touarra; e como parte con Ysa, e con las Peñas de San Pedro [...]" (Ballesteros, 2004, p. 217).

\section{Marco geográfico y natural}

Isso se sitúa al oeste de Hellín, en una penillanura cuya altitud oscila entre los 400 y los 500 m.s.n.m., en la margen izquierda del río Mundo, afluente del Segura. Su clima es de tipo mediterráneo con tendencia a la continentalización, al encontrarse al piedemonte de la meseta. Las precipitaciones se concentran en los meses de abril y octubre, aunque no sobrepasan los $600 \mathrm{~mm}$ anuales. Las temperaturas máximas se dan en julio y agosto, y las mínimas 
en enero, siendo poco frecuentes las heladas (Losada, 1986, p. 144).

El territorio está surcado por numerosas ramblas que discurren de norte a sur: al este está la del Pepino, en la cual confluyen la del Payuelas y Boquerón; al oeste se localizan las del Pedernaloso, Honda y Quebrada. Todas ellas se originan en la cadena de sierras que hay al norte (Montesinos, Romeral, Higuerica y Quebradas), y desembocan en el río Mundo. Presentan un caudal temporal u ocasional relacionado con las lluvias, especialmente con las de carácter torrencial (Fig. 7).

La vegetación es escasa por el fuerte impacto que ha tenido la agricultura, especialmente el cultivo del esparto, y la tala de la mayor parte de los bosques, de los que son testigos pequeñas extensiones de pinares, si bien han comenzado a proliferar extensas parcelas repobladas con pinos en los últimos tiempos.

\section{Vías de comunicación}

Las actuales poblaciones de Hellín e Isso se sitúan en una llanura bordeada por elevaciones. Este territorio es, por ello, un nudo natural de comunicaciones con importantes rutas que lo han atravesado a lo largo de la historia.

Durante la época romana, el asentamiento que vertebró todo el territorio fue el Tolmo de Minateda, identificado tradicionalmente con la ciudad de Ilunum (Fig. 3). Junto a ella discurrían dos ejes principales de comunicación: la vía que unía las ciudades de Complutum (Alcalá de Henares) y Carthago Nova (Cartagena), y la que conectaba Cástulo (Linares) y Sagunto (López Precioso, 1993). Esta segunda pasaba por el territorio de Isso, cruzando el río Mundo a la altura a la que se encuentran dos puentes históricos que se han considerado erróneamente obras romanas (Selva Iniesta, Jordán Montés, 1988, p. 87). López Precioso ha propuesto además otras vías secundarias que pondrían en comunicación el poblamiento disperso de esta zona, donde se localizan los yacimientos del Poblado del Prao, Fuente de Isso y Casa Grande, este último con una ocupación muy tardía que llega hasta el periodo visigodo. Las dos vías más relevantes son las que conectaban el Tolmo de Minateda con la Puerta de Segura, siendo esta utilizada desde época ibérica, y la que comunicaba la zona de Isso con Liétor (López Precioso, 1993).

El documento gráfico más antiguo que conocemos del territorio de Hellín, en el que se incluyen Isso y Tobarra, es el denominado Plano Croquis de la Villa de Hellín, Rno de Murcia executado por el Ayudte. Gen. Dn. Josef More$t e^{4}$, fechado el 16 de marzo de 1811 (Fig. 5). La población de Hellín aparece señalada con el $\mathrm{n}^{\circ} 1 \mathrm{y} \mathrm{su}$ "Castillo antiguo totalmente arruinado" con el 2. Lo más destacable en este documento son los caminos, que muestran una estructura radial confluyente en Hellín. También aparecen ciertos accidentes geográficos, como el "Arroyo de Tobarra que pasando por Agramón va al río Mundo", situado al este, y el río Mundo, emplazado al oeste. Se distinguen las vías que permitían el paso de carruajes, señaladas con la letra "C", de las que sólo admitían caballerías debido a su estrechez, marcados con la letra "h". A continuación haremos una breve mención de todos ellos.

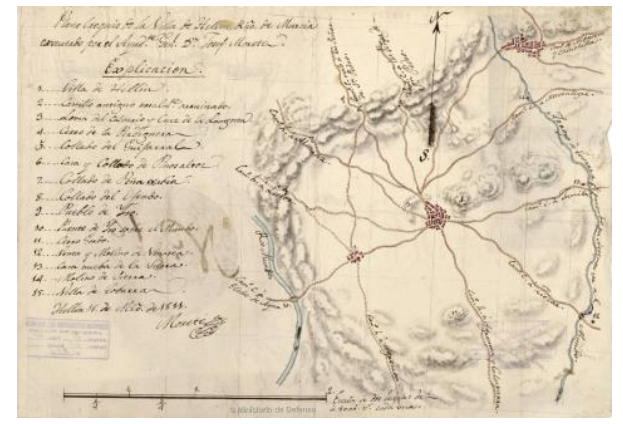

Fig. 5. Hellín. Plano de su territorio (1811).

Hacia el oeste, donde encontramos la sierra de Alcaraz, se dirigen dos caminos que la cruzan para alcanzar el flanco meridional de la submeseta sur, en las proximidades de Alcaraz. El primero, tras cruzar el río, discurre por la margen derecha y está señalado como " $\mathrm{Cam}^{\circ} \mathrm{c}$. [Camino carretero] a Elche de Ayna"; al cruzar el río en dirección a Elche de la Sierra, se indica la existencia de un puente, señalado con el $\mathrm{n}^{\mathrm{o}} 10 \mathrm{y}$ denominado "Puente de Iso sobre el Mundo". Actualmente existen dos puentes en 
las cercanías del paso de la carretera que une Hellín con Isso (CM-412) por el río Mundo, situados a 4,3 km de Isso: uno de ellos parece ser obra del siglo XVIII por los tajamares que lo defienden de la corriente del río (Fig. 6); el otro, más antiguo y emplazado aguas abajo, podría ser medieval o de comienzos de la Edad Moderna. Su presencia da idea de la importancia de este lugar como vado fluvial y punto clave de comunicación a lo largo de la historia.

El segundo discurre por la margen izquierda del río Mundo y aparece como "Cam ${ }^{\circ} \mathrm{h}$. [camino de herradura] a Lietor"; sobre la línea que lo define se aprecia el $\mathrm{n}^{\circ} 8$, refiriéndose al "Collado del Ofeado". Además de llegar a la localidad de Liétor, alcanzaba las de Ayna y Bogarra. Esta vía se encuentra documentada desde época tardo-ibérica, pues en relación a ella se han interpretado tres asentamientos de esa cronología (Casa de la Marta-1 y 2, y Talave) situados en sendas vegas aluviales del río Mundo (López Precioso, 1993, pp. 110, 111, 124). Según López Precioso, habría que poner en relación el topónimo del "Camino de la Losilla" con el tramo inicial de esta ruta entre Isso y Hellín, que indicaría la presencia probable de una calzada.

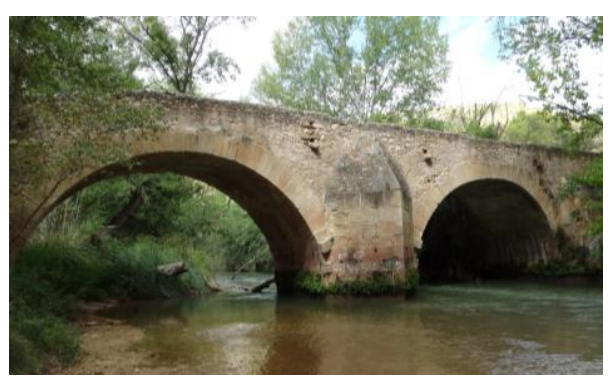

Fig. 6. Isso. Puente sobre el río Mundo.

En dirección noroeste tenemos otros dos que se dirigen a Peñas de San Pedro. El primero está indicado como " $\mathrm{Cam}^{\circ} \mathrm{C}$. malo a las Peñas de Sn. Pedro" y en dos puntos diferentes de su trayecto está rotulado el $\mathrm{n}^{\circ} 6$, señalando el emplazamiento de la "Casa y Collado de Pinos altoz". El segundo, aparece como " $\mathrm{Cam}^{\circ} \mathrm{C}$. a las Peñas de Sn. Pedro" y sobre la línea que señala el camino está dibujado el $\mathrm{n}^{\circ} 5$, que hace referencia al "Collado del Guifarrala".
En dirección noreste tenemos el " $\mathrm{Cam}^{\circ}$ de $\mathrm{Al}$ bacete y Chinchilla" que pasa por la "Villa de Tobarra". Se trata, en definitiva, de un sector del tramo meridional de la vía romana que enlazaba Cartago Nova y Complutum, que a la altura de Hellín discurría por el Tolmo de Minateda, Torre Uchea y Sierra, es decir, al este de las localidades de Hellín y Tobarra (López Precioso, 1993, pp. 116-118). Por tanto, los viales representados en el plano de 1811 en dirección a Cieza (hacia el sur) y Chinchilla y Albacete por Tobarra (hacia el norte), son dos tramos que enlazan Hellín con la mencionada ruta de origen romano y, por consiguiente, se debieron de originar en la Edad Media, al tiempo que surgió esta población.

En dirección este localizamos el " $\mathrm{Cam}^{\circ} \mathrm{C}$. a Montealegre" que en su intersección con el arroyo de Tobarra está rotulado con el $\mathrm{n}^{\circ} 14$, indicando el emplazamiento del "Molino de Sierra", nombre que hace alusión a la zona en la que se encuentra el despoblado andalusí homónimo. Pasado Sierra, se dirigía a Albatana, Ontur, Montealegre (Pechín, en la Edad Media) y desde allí al Levante a través del corredor de Almansa y la cabecera del valle del Vinalopó.

También hacia el este se señala el " $\mathrm{Cam}^{\circ} \mathrm{C}$. a Jumilla" que en su intersección con el arroyo de Tobarra está marcado con el $\mathrm{n}^{\circ} 13$, indicando la ubicación de la "Casa nueba de la Sierra". Seguramente se trata de un tramo que vendría a enlazar con la vía que comunicaba el Tolmo de Minateda con Jumilla desde la Antigüedad y que actualmente recorre la CM-3212. Según López Precioso "La vía arranca desde el Tolmo de Minateda para dirigirse rumbo este a través de las sierras de "En medio" y del "Candil", siguiendo por la actual carretera local de "La Celia", lugar en donde existe una mina de oligisto para la explotación del hierro [...]" (1993, pp. 119-120). El tramo representado en el mapa de 1811 pudo correr algo más al norte, modificación debida al despoblamiento del Tolmo y al desarrollo de Hellín.

Más al sur, en dirección sureste, tenemos el "Cam ${ }^{\circ}$ C. a Ziezar" que en su intersección con el arroyo de Tobarra está señalado con el $n^{\circ}$ 
12, indicando el emplazamiento de la "Venta y Molino de Vinatea". Se trata, como decíamos anteriormente, de un tramo de la vía romana que se dirigía a Cartagena $\mathrm{y}$, a partir de la Edad Media, a Murcia, pasando por el Tolmo de Minateda y Cieza. Desde este último enclave el camino de herradura medieval continuaba por el valle del Segura, mientras que la calzada romana y la carretera moderna lo hacían por las elevaciones del puerto de la Losilla.

Tenemos una ruta secundaria, que no pasa por Hellín, en la que Isso es protagonista: la que ponía en contacto Agramón (sur) con Peñas de San Pedro (norte), a través del "Cam ${ }^{\circ}$ C. malo a las Peñas de Sn. Pedro".

Desde Isso, en dirección norte, la ruta que acabamos de mencionar pasa por la Fuente, que no aparece representada en el mapa de 1811. En este paraje se produce un cruce de antiguos caminos que indica la importancia histórica de esta surgencia, especialmente utilizada por la ganadería trashumante.

Otro camino que no está representado en el plano de 1811, pero que sí se distingue en otros de 1878 y 1893 con el calificativo de "Camino de la Fuente de Iso", es el que actualmente se conoce con el nombre de "camino viejo de Isso".

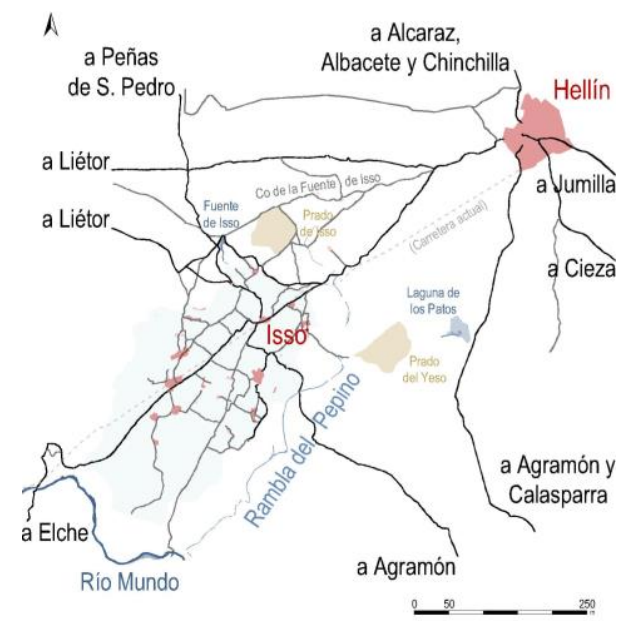

Fig. 7. Rutas y caminos principales en el entorno de Isso.
Por último, cabe destacar que entre las vías pecuarias que atraviesan el término de Isso se encuentra la Cañada Real de los Valencianos, importante camino tradicional para el comercio y la trashumancia entre las tierras del Levante y las sierras de Alcaraz y Segura (López Montoya, 2002, p. 144).

\section{Economía de la zona}

No disponemos de una mínima información para conocer, de manera directa, la economía desarrollada en el territorio de Isso en época medieval, por lo que utilizaremos datos de épocas más recientes, siendo conscientes de la prudencia que hay que tener con ellos cuando se pretende proyectarlos a un periodo anterior. Otro inconveniente que es necesario advertir, es que la documentación manejada, en su mayoría, no se refiere directamente a Isso, pues lo habitual es que se trate de textos referidos a Hellín, territorio en el que Isso quedó englobado desde la Edad Moderna.

El primer documento que recoge información de carácter económico es el Censo de Pecheros de Carlos I, de 1528, en él se dice que Hellín es: "Villa con muchos ricos. La mayor parte de los vecinos son tratantes en alfombras y paños, los otros son hortelanos que cogen mucho pan, vino y algún aceite. Tienen moreras y frutales. Las mujeres ganan mucho haciendo alfombras" (Alcaide, 2008, p. 395).

En las Relaciones Topográficas (1576) referidas a Hellín, se indica que: "la mayor parte de los terminos de la dicha villa son sierras asperas e montosas e rriscos de peñas e tierras desaprouechadas, que solo naçen en ella atochas, rromeros e otras matas desaprovechadas e algunos pinos, que no sirben mas de para leña, y algunos entrellos para madera corta para edifiçios de casas" (Carrilero, et al., 2014, p. 116).

Los troncos extraídos de los pinos cortados en las sierras de la comarca de Hellín solían ser transportados por los llamados gancheros a través de los cauces de los ríos Segura y Mundo. Así, en el lecho de este último, junto a los puentes ya mencionados, se distingue una plataforma de piedra de planta triangular dispues- 
ta por los gancheros para empujar los troncos con el fin de que no quedaran varados en la orilla.

En el mismo texto de las Relaciones Topográficas hay alusiones a los animales que se podían cazar en sus montes: "en la dicha villa se cria caça de conejos, perdizes, liebres, y en algunas sierras del termino se crian algunas cabras e machos monteses, espeçialmente en la sierra de la Peña Bermeja y en la sierra las Cabras y Pero Pastor e Cuchillo de Minateda y en la Peña Labar" (Carrilero, et al., 2014, p. 116).

Además de los recursos que proporcionaba la caza, también se aprovechó la escasa pesca que se obtenía en las fuentes y en el río Mundo: "En los dichos rrios e fuentes del dicho termino ay algunos peçes en poca cantidad, de los quales dichos peçes se aprovechan todos los vezinos de la dicha villa en general" (Carrilero, et al., 2014, p. 118).

Tomás López en Las Relaciones Geográfico Históricas de Albacete (1786-89), menciona que en los montes del término de Hellín: "se crían pinos de toda leña, matas de lentisco grandes, y en abundancia; chaparras; romero; madroñeras, quiebraollas, Arnachos, Estepa, y sobre todo Atocha que abunda tanto, que en el término creemos se puede cojer Esparto para avastezer a todas las fábricas de la gran Bretaña, y tan superior que [tira] regularmente 5 palmos, y en algún paraje vara/ y media: también se crían linteros y otras varias matas" (Rodríguez, Cano, 1987, p. 316).

En el Catastro de Ensenada (1749) se explica que las tierras del término de Hellín se dividen entre las de regadío y las de secano, y cada una de estas categorías a su vez en diferentes niveles de calidad:

"que las especies de tierra que hay en el término de esta villa son de regadío y secano: Que en el regadío hay de hortaliza, moreral cerrado, labradío con moreras, labradío sin ellas, arrozal, azafranar, viñas y olivares; y en el secano de labradío, azafranar, montes de esparto, monte alto de pinos e inútiles por naturaleza. Que el moreral no produce más que hoja; el labradío regadío con moreras; y sin ellas de buena y mediana bondad producen sin intermisión, un año cáñamo, otro trigo, y otro cebada $y$ de inferior una sola cosecha de trigo, con descanso de dos años. Las de labradío secano de buena calidad producen seguidamente una cosecha de trigo y otra de centeno y descansa tres años; las de mediana una cosecha de trigo con intermisión de cuatro; y las de inferior otra igual cosecha de trigo, descansando seis, el azafranar produce cuatro cosechas en cinco al año [...] las especies de árboles que hay en el término de esta villa son moreras y olivos [...] los plantíos de moreras y olivos se hallan puestos en las tierras de regadío"s.

Mariano Nipho en su Relación del Corregimiento de Hellín (1770), indica que: "Regularmente produce el término de Hellín el Trigo, Cebada. Centeno, y Panizo, que necesita para su consumo, y el sobrante del Trigo se extrae por las cabañas de los vecinos de dicha Villas para Murcia, y Valencia, la cosecha del arroz es más abundante, y no solo se provee de ella la población de Hellín, sino que se surte con él a otros Pueblos inmediatos. La cosecha de vino, y aceite regularmente no basta para el consumo de este pueblo: la seda es reducida: el azafrán abunda, y se extrae para Murcia y Andalucía: la de barrilla es muy corta, y se saca para las Fábricas de Cristales del Reino, y también para las de jabón, con alguna corta cantidad de sosa. La cosecha del cáñamo es de bastante consideración, cuyo fruto regularmente se consume en muchos Pueblos de la Comarca, a excepción del que consumen los vecinos de esta Villa en lienzos bastos. Todos los demás frutos de Hortalizas, legumbres, y frutas que produce la Huerta, no alcanzan para el consumo de su vecindario, y para subvenir a esta urgencia se surte de hortalizas, y legumbres de la Huerta de Murcia" (Nipho, 1770, p. 246).

Los escasos datos que conocemos referidos directamente al territorio de Isso los proporcionan de nuevo las Relaciones Topográficas: "[...] la dicha villa de Hellín tiene a media legua della la guerta y heredades de moreras, viñas de pasa e vino e tierras que llaman de Yso" (Carrilero, et al., 2014, p. 118). 


\section{El sistema hidráulico tradicional de Isso}

La situación del río Mundo a su paso por el territorio de Isso imposibilita el uso de sus aguas para el regadío, pues se sitúa a una cota inferior a la de las tierras susceptibles de ser cultivadas. Este problema ya se pone de manifiesto en Las Relaciones topográficas: "[...] los dichos ríos e agua de ellos en la dicha uilla de Hellín no se aprovechan de ellos ni de algunos de ellos para regar con los dichos rios ni algunos de ellos porque ban por tierras asperas, sierras, riscos e montosas e van muy hondos de manera que no ay tierras de riego en ellos" (Cebrián, Cano, 1992, p. 153).

Esta situación hace que sean los manantiales, cuyas aguas proceden de la masa freática del Boquerón, los que soportan el sistema de regadío, tanto de Isso como de algunos municipios de la comarca de Hellín. Esta se localiza en la margen izquierda del río Segura y se alimenta, principalmente, por la infiltración del agua de lluvia en afloramientos permeables. Las principales surgencias de agua asociadas a ella son: La Pestosa, la del hilo de Polope y la de las Mercedes, pertenecientes a Tobarra, y la de Isso a Hellín (Aragón, 2010, pp. 1-7).

La fuente de Isso, enclavada sobre un material cuaternario suprayacente a 513 m.s.n.m., se localiza a $1,7 \mathrm{~km}$ al norte de la fortaleza; de esta surgencia nacen tres acequias principales que vertebran toda la zona irrigada, dos perimetrales y una central, de las que parten numerosos brazales y regueras (Fig. 8).

En Isso existe además otra fuente, denominada del Bache, situada a 490 m.s.n.m. y localizada a unos $1,5 \mathrm{~km}$ al oeste del núcleo, la cual, aunque aporta agua en menor medida, apoya al sistema de acequias en su zona oeste (Fig. 9). En las cercanías de esta fuente se construyó una balsa destinada a la industria del cáñamo en el siglo XX.

El aprovechamiento de la fuente de Isso parece remontarse al Neolítico, periodo en el que fue datado un yacimiento situado en sus proximidades (Jordán, 1992, pp. 202-203; García, López, 2010).
El origen del sistema hidráulico asociado a la fuente de Isso podría remontarse a la Edad Media y posiblemente a época andalusí, aunque solo podemos inferir este hecho a través de su relación con el poblamiento, pues no tenemos constancia de su existencia antes de finales del siglo XV. En ese momento, la red de acequias ya contaba con unas ordenanzas que regulaban su mantenimiento, según sabemos por un documento de 1494, en virtud del cual los Reyes Católicos instaron a las autoridades de Hellín a que cumpliesen e hiciesen cumplir las citadas ordenanzas, por lo que entendemos que el sistema no se encontraba en buen esta$\mathrm{do}^{6}$. No sabemos si este documento hace referencia exclusivamente a las acequias de Hellín o si también incluía las de Isso. En cualquier caso, los problemas en la red hidráulica de Isso quedan evidenciados en un documento de 1527 , firmado por Carlos I y su madre y dirigido al gobernador del marquesado de Villena, para que representantes de la villa de Hellín prestasen juramento de calumnia en el pleito sobre el aprovechamiento de la Fuente de Isso (Carrilero, 2000, pp. 131-133). El trasfondo de este pleito entre Albacete y Hellín parece ser un conflicto entre ganaderos y agricultores por la propiedad de la tierra y el uso del agua (Pretel, 1998, pp. 131-133).

En las Relaciones Topográficas de Felipe II (1576) ya se hace una detallada descripción de la fuente y de la huerta de Isso:

"La dicha villa de Hellin tiene a media legua della la guerta y heredades de moreras, viñas de pasa e vino e tierras que llaman de Yso, questa es de veçinos de la dicha villa de Hellin, y estara rrepartida entre çien personas, la qual es de rriego e se rriega con el agua de vna fuente que tiene, que salen dos hilas de agua, e que tanbien entre otros veinte o treinta personas tienen las heredades e guerta de Minateda, Agramon e Vçhea breches, queba Dubacar [Ubacar] Alazeraque, questas son de viñas de pasa e vino, e tierras de labor e moreras de rriego, que se rriegan con el agua de las fuentes que naçen en las dicha eredades, ques en poca cantidad" (Carrilero, et al., 2014, p. 119). 

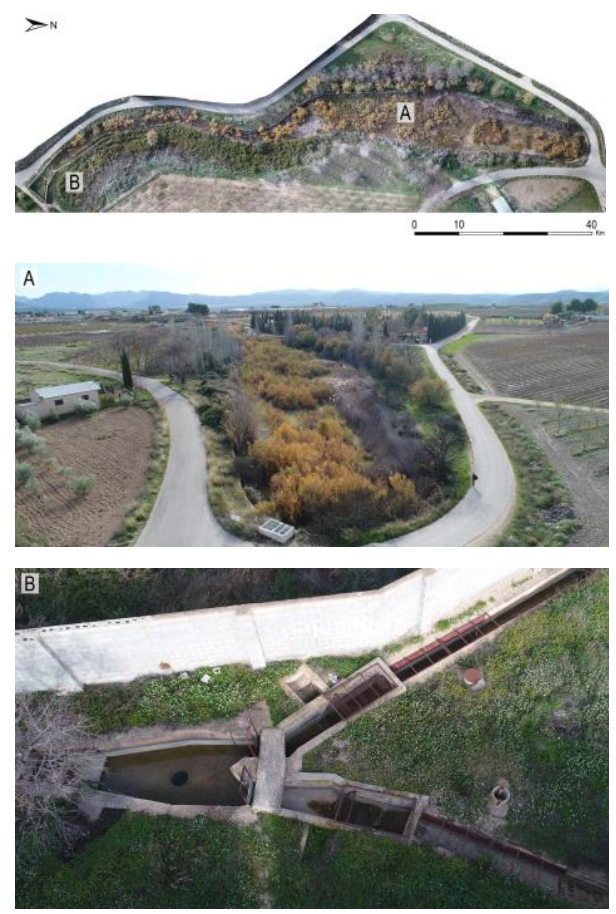

Fig. 8. Fuente de Isso. Ortofotografía. (A) Surgencia de agua. (B) Partidor que divide el agua en dos acequias principales.

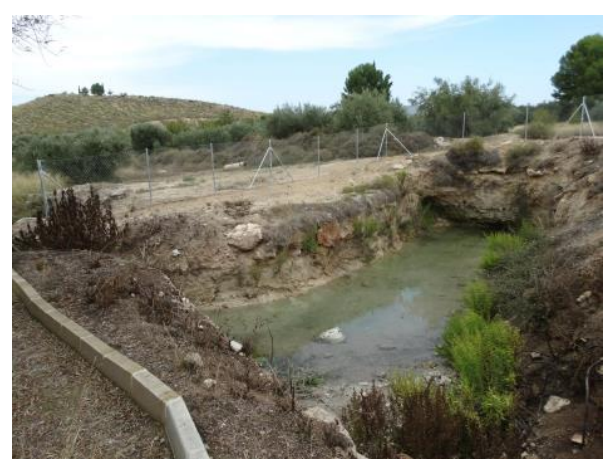

Fig. 9. Isso. Fuente del Bache.

El mismo documento refiere la existencia de algunas infraestructuras hidráulicas a lo largo del trazado de la red de acequias, en concreto, cuatro molinos harineros y tres batanes:

"y en la rribera de la dicha guerta de Yso ay dos molinos de dos rruedas en cada vno vna y dos casas de batanes questos se sirben sus amos, e otro batan desbaratado y que no se aprovechan del, e de cada vno de los dichos dos batanes rrentara hasta seis mill maravedis, y el vn molino esta moliente e corriente, ques de Maria Carrasca, biuda de Rodrigo de Valcarçel, rrentara hasta veinte e çinco o treinta hanegas de trigo, y el otro molino no se aprovechan del" (Carrilero, et al., 2014, p. 119).

La fuente de Isso también aparece citada por Tomás López en su libro Relaciones geográfico-históricas de Albacete (1786-1789), al enumerar las fuentes existentes en Hellín: "También se quentan en este término hasta 17 fuentes algunas de ellas de gran tamaño, $[. .$.$] y$ la que naze sobre el heredamiento de Ysso del este término riega otra porción higual a las de esta Villa (de Hellín) en la que también ay un Molino de la misma especie, y las demás en dispersos parajes en los que a proporción de sus aguas riegan, y fertilizan varios pedazos de tierra" (Rodríguez, Cano, 1987, p. 315).

Los principales diccionarios publicados durante el siglo XIX mantienen las referencias tanto a la fuente como a su uso agrícola. El Diccionario geográfico-estadístico de España y Portugal (1826-1828) de Sebastián Miñano, al describir las aguas de Hellín y su término señala que: "Hay otra fuente de dos hilos en el heredamiento de Iso, que riega una deliciosa huerta" (Miñano, 1826, p. 440).

En el Suplemento que hace Miñano a su diccionario en 1829 , ofrece una descripción más detallada:

"A la parte del S. de esta huerta [de Hellín], a su continuación, y como á $1 / 2$ leg. [legua] de dist., se encuentra la del lugar de Iso, cuya long. excede de $1 / 2$ leg., y $1 / 4$ de latitud, terreno fértil y pintoresco por estar en declive suave y compuesto de cañadas y alturitas sobre las que están edificadas las casas que son más de 300 . La desigualdad del terreno, la diversidad de árboles y plantas, la variedad de verdes, junto con la blancura de las casas, reunidas en pequeños grupos, hacen una vista deliciosa. Para su riego solo tiene una fuente que, aunque dividida en dos hilos, la cantidad de agua es 
igual a la de Hellín. El hidrofilacio o lago de estas fuentes, debe ser extraordinario por no menguar en las sequedades que agotan las fuentes más copiosas; debe salir el agua a la superficie por un conducto metálico de extremada solidez, puesto que la cantidad siempre es la misma, aun cuando la abundancia de lluvias y nieves produzcan considerable aumento en el lago" (Miñano, 1829, p. 342).

El Diccionario de Pascual Madoz (1845- 1850) es más parco informando sobre la Fuente de Isso, limitándose a señalar su existencia e indicando que tiene igual cantidad de aguas que la de Hellín (Madoz, 1847, p. 165).

A pesar de que la fuente ha dado históricamente un buen caudal, la excesiva partición de las tierras fue generando problemas en el riego, tal y como se refleja en un documento de 1860: "Los propietarios del agua de la fuente de Ysso [...] exponen: que por el gran fraccionamiento que la desvinculación y la acción continua de rentas y partición de herencias han producido, se halla subdividida el agua de dicha fuente de modo que teniendo muchos de sus dueños repartidos sus porciones en diferentes días de la semana sufren ellos, y sufre el riego en general de aquel heredamiento grandes perjuicios, que es de suma urgencia remediar por medio de la oportuna desenvoltura". ${ }^{7}$

Todos estos documentos nos aportan numerosos datos sobre un sistema hidráulico que ha permitido el cultivo del territorio de Isso, al menos, desde el siglo XV. Sin embargo, no es hasta la publicación de las Ordenanzas de la Comunidad de Regantes de la Acequia de Isso (Hellín), constituida en 1879, cuando contamos con una descripción más precisa de la red $^{8}$. Este documento nos ha permitido constatar los datos obtenidos de la recomposición de su trazado, que se ha desarrollado a partir del análisis de los diferentes vuelos fotogramétricos que se llevaron a cabo a lo largo del siglo XX, especialmente el realizado por Ruiz de Alda en 1929-30.
Como ya se menciona tanto en las Relaciones Topográficas de Felipe II, como en el Diccionario geográfico-estadístico de Sebastián Miñano, el agua de la fuente se reparte, inmediatamente después de la surgencia, en dos acequias principales que la distribuyen por todo el perímetro de la zona irrigada de Isso, una en dirección sureste y otra en dirección oeste (Figs. 8 y 11). La primera aparece denominada como "hilo de Hyso" o "hilo Llorón" en las Ordenanzas de Regantes, y recorre los barrios del Toladillo, Asomadilla, Perchel y Grederos, antes de desembocar en la rambla del Pepino. La segunda se le conoce como "hilo de la Fuente", recorre los barrios del Pino y Peropaile, y desemboca en la rambla del Pedernaloso.

A estas dos se suma una tercera acequia principal que recorre la zona irrigada por su parte central, desembocando en el río Mundo, y que sí es recogida por las Ordenanzas de Regantes, a diferencia del resto de documentos mencionados, aunque no se le asigna ningún nombre: "Otro hilo, consecuencia de la fusión de los dos anteriores, en su nacimiento, que recorre los parajes denominados "La Cerca", "Casa la Parra", "Quiles" y "Casa Baltasar", desembocando en la rambla del río Mundo o "Rambla del Moreno"'. Esta acequia aparece, efectivamente, como una bifurcación del "hilo de la Fuente", a unos $330 \mathrm{~m}$ del partidor, y su caudal se ve alimentado no sólo por esta acequia sino también por el "hilo de Hyso" o "hilo Llorón", a través de un ramal que se encuentra con esta acequia a unos $324 \mathrm{~m}$ de su nacimiento, y que denominaremos, a partir de ahora, "acequia de la Fuente" (Fig. 11).

La existencia de esta acequia es capital para entender el desarrollo de la fortaleza de Isso, pues discurre a escasa distancia de su frente occidental; en esta zona, se eleva sobre un acueducto construido con mampuestos irregulares tomados con mortero de cal y dispuestos en hiladas poco definidas, para salvar el desnivel del terreno (Fig. 10). 


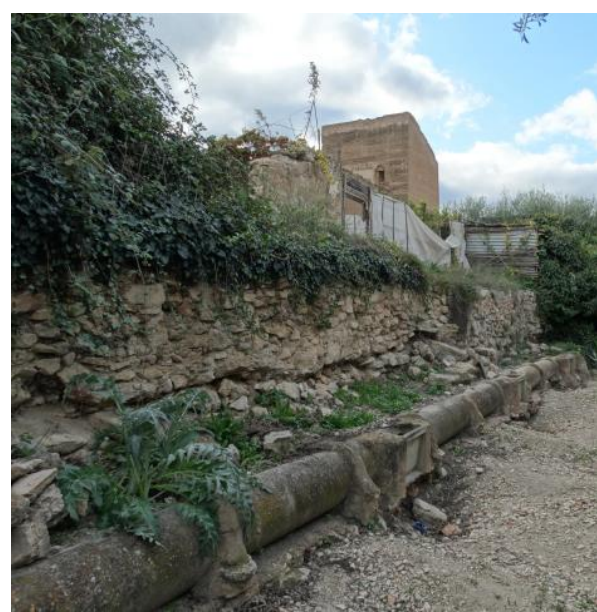

Fig. 10. Isso. Arriba a la izquierda, el acueducto de mampostería por donde discurre la acequia de la fuente. En paralelo y a una cota más baja hay una acequia menor que actualmente discurre por el interior de tubos de cemento. Al fondo, la torre suroeste de la fortaleza.

De estas tres acequias principales nacen una serie de brazales (acequias secundarias) que reparten el agua por toda la zona irrigada, acercándose a los diferentes núcleos de poblamiento que conforman la pedanía de Isso, y de ellas, regueros (ramales transversales) que permiten la irrigación directa de cada huerta (Fig. 11).

Prácticamente la totalidad de la red fue entubada en la segunda mitad del siglo XX, por el Instituto Nacional de Reforma y Desarrollo Agrario (IRYDA), dentro de su plan de puesta en cultivo de nuevas tierras y mejora de los regadíos. Por ello, hoy en día su trazado es prácticamente irreconocible.

El tramo mejor conservado se localiza en las proximidades del caserío de Isso, muy cerca del lienzo oeste de la fortaleza, donde aparece el acueducto anteriormente mencionado. Es esta estructura la que ha permitido que el trazado de la acequia siga siendo visible, a pesar de que el curso de agua esté entubado, al igual que el brazal que discurre a sus pies (Fig. 10).

La prospección realizada tanto en el entorno como en el caserío de Isso, no ha identificado ninguna alberca destinada al almacenamiento del agua procedente de la acequia, aunque sí ha localizado un aljibe situado en la vivienda de la parcela $n^{\circ} 9$. Es posible que éste fuese abastecido por un ramal secundario procedente de la acequia principal en las cercanías del caserío.

A pesar de lo precaria que es la información disponible, podemos concluir planteando la hipótesis de que la estructura del sistema hidráulico de Isso es de origen andalusí y que en sus huertas se cultivaron los productos que se pueden explotar cuando se dispone de irrigación continua.

\section{Estructura del poblamiento de Isso}

La pedanía de Isso está compuesta por más de una treintena de pequeños asentamientos diseminados por su huerta, encabezados por el núcleo formado en torno a la fortaleza y a la carretera que pasa a sus pies (CM-412). Todos ellos se han desarrollado en función del cultivo de las tierras adyacentes, y comparten un mismo patrón de implantación territorial sobre cerros de poca altura, de manera que ocupaban espacios que difícilmente podían ser irrigados. Esta ubicación también les permitía el control visual del territorio a la vez que les facilitaba la defensa en caso de necesidad. Esta disposición tan particular llamó la atención a Sebastián de Miñano a comienzos del siglo XIX, cuando reparó en que el territorio de Isso tenía unas "alturitas sobre las que están edificadas las casas que son más de 300" (Miñano, 1829, p. 342).

Dentro de este numeroso grupo de asentamientos, y según su desarrollo hasta la actualidad, podríamos establecer dos categorías en función de su tamaño. Los más extensos y con mayor población son considerados "barrios", aunque también se les conoce popularmente como "cerros", mientras que a los más pequeños se les llama "casas"; a estos últimos los podríamos equiparar con cortijadas. El actual Mapa Topográfico Nacional (escala 1:25.000), elaborado por el Instituto Geográfico Nacional, es el que nos ha servido de base para diferenciar entre barrios y casas. 


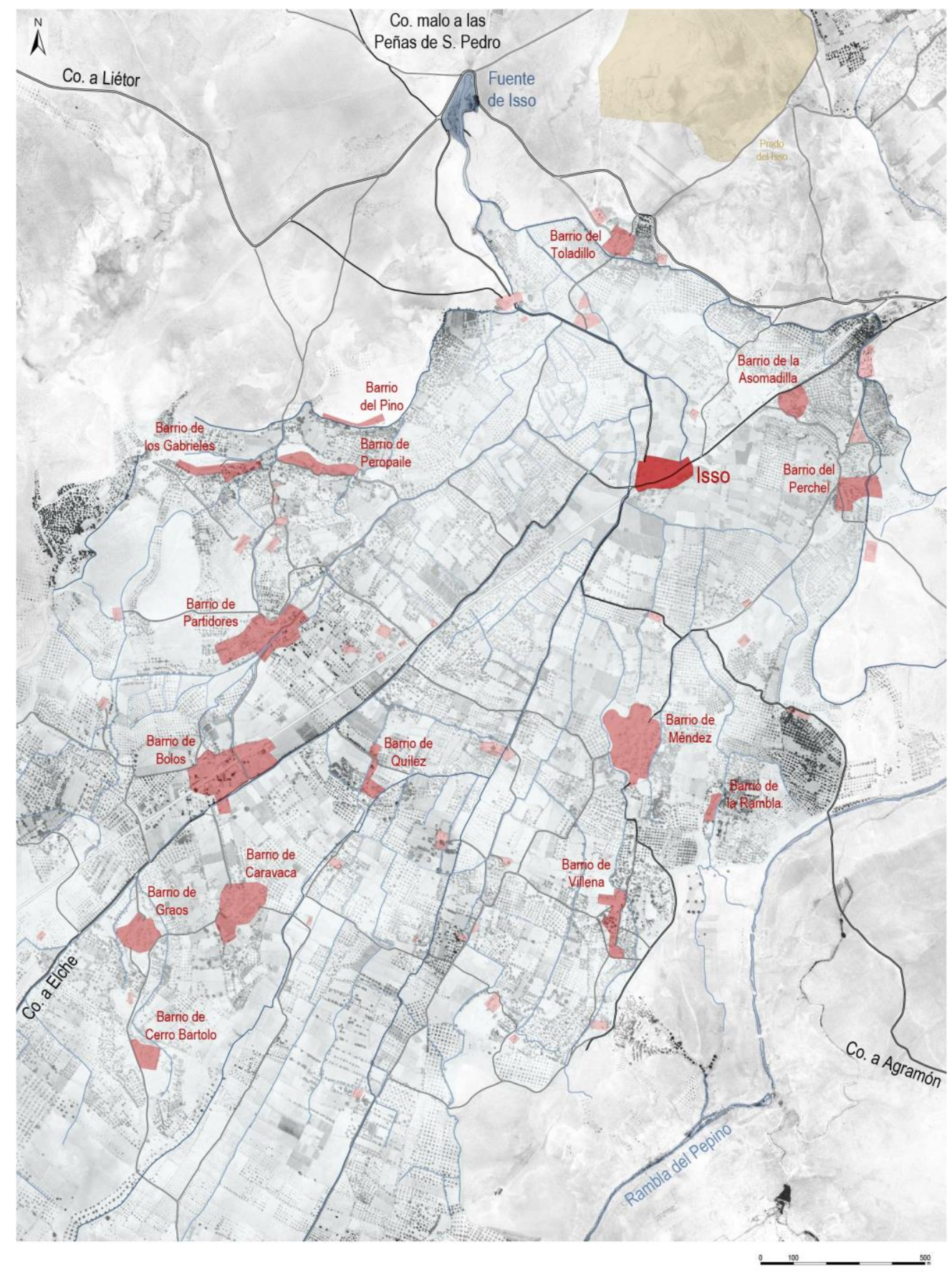

Fig. 11. Isso. Situación de los barrios y trazado de las principales acequias, brazales y regueras de la zona irrigada. Base cartográfica: vuelo aerofotográfico de Ruiz de Alda (1929-1930). 
De algunos asentamientos existen referencias documentales desde el siglo XVIII, como es el de Pero Paile o el de la Asomadilla, llamados "sitios" por el canónigo Lozano (Lozano, 1794, p. 36). De hecho, buena parte de ellos ya están recogidos en un plano topográfico de la Provincia de Albacete, realizado en 1878 y actualizado en 1921, 1951 y $1965 .^{9}$

En algunos casos, incluso, como veremos a continuación, los restos arqueológicos hallados en sus proximidades prueban la existencia de asentamientos que podrían remontarse a la Antigüedad Tardía.

Para el estudio de estos asentamientos, se ha llevado a cabo una labor de identificación y de análisis de su desarrollo urbanístico a lo largo del siglo XX, así como de su toponimia; para ello, hemos utilizado el plano topográfico de 1878, anteriormente mencionado, y el vuelo fotogramétrico realizado por Ruiz de Alda (1929-30). A través de este análisis, se han identificado diferencias en el grado de compacidad de sus edificaciones y del propio urbanismo de estos núcleos. Todos los barrios existentes en 1878 han llegado hasta la actualidad, excepto el de Buendía (Fig. 11).

Por una parte, encontramos una serie de barrios en los que las edificaciones se disponen de manera compacta, respondiendo claramente a la topografía del cerro sobre el que se asientan y desarrollan un urbanismo propio a partir del paso de uno o varios caminos que comunicaban estos núcleos entre sí, y que articulaban el espacio cultivado del entorno de Isso. Éstos ya eran considerados barrios en 1878 y aunque actualmente todos ellos han sufrido un cierto grado de desarrollo, viendo aumentada su extensión, aún conservan el urbanismo de su núcleo originario. Hablamos de los barrios del Toladillo, de la Asomadilla, de Méndez, de Caravaca, del Grao, de Bolos, de Partidores y, por supuesto, del Barrio de Isso, que es el núcleo originado en torno a la fortaleza. Incluimos en este grupo también a los barrios del Perchel, de la Rambla, de Villenas, de Quílez, de Cerro Bartolo, de Peropaile, Gabrieles y Pino ya que, aunque presentan un desarrollo lineal asociado a acequias o caminos, ya en
1878 tienen un grado de desarrollo importante y son considerados barrios.

Por otra parte, identificamos una serie de núcleos que se han desarrollado a partir de una o varias casas aisladas y dispersas, en ocasiones con grandes espacios cercados, situadas en relación a los caminos que articulaban la huerta, y habiéndose expandido, generalmente, de manera lineal en función de ellos. Estas casas han dado lugar a un desarrollo en su entorno, apareciendo en la actualidad como barrios compuestos por pocas edificaciones y con un urbanismo que nada tiene que ver con los núcleos compactos anteriormente descritos. En este grupo incluimos los actuales barrios de Almeces, de Canteros, de Castor, de las Celdias, de la Cerca, de Grederos, de Tejera y del Prado $^{10}$. Dado el gran número de asentamientos que hemos identificado, sólo trataremos a continuación aquellos que son considerados barrios en el plano topográfico de 1878 .

Barrio del Toladillo (Toledillo). Situado al norte de la fortaleza, en el camino del Prado de Iso, según es denominado en el plano de 1878. En 1929-30 ya se aprecia un núcleo compacto cuya morfología no ha variado hasta la actualidad. Emilio Molina propuso ubicar en la falda del cerro de este barrio la antigua ciudad de Hellín (Molina López, 1971, p. 76). En este paraje se encuentran los restos de un poblado ibero-romano.

Barrio de la Asomadilla. Está situado al noreste de la fortaleza, junto a la carretera CM412. En el plano de 1878 se le representa como un núcleo compacto en cuyas inmediaciones hay una serie de edificaciones emplazadas a lo largo del camino de la Asomadilla. Su topónimo es muy común en Castilla La Mancha, y está referido a un lugar ubicado en altura desde el que se puede contemplar el paisaje o controlar su territorio circundante. El canónigo Juan Lozano, para demostrar la antigüedad de Isso, hace referencia a las ruinas que se conservaban dispersas en su término, señalando que: "En el sitio que llaman la Asomadilla aparecen vestigios de pequeña población" (Lozano, 1794, p. 36). 
Barrio del Perchel. Localizado al este de la fortaleza, está conformado por una serie de casas que se sitúan junto a los caminos de la Asomadilla al Barrio de Mendez y de la Asomadilla al Prado del Ieso, y a una de las acequias perimetrales, al norte del barrio de Grederos. Aunque aparece denominado como barrio en el plano de 1878, en 1929-30 se aprecian varias agrupaciones de casas dispersas. Según R. Pocklington, el nombre de Perchel se deriva sin dificultad del latín partǐcělla "parcela" con la consabida pérdida de -A del diminutivo femenino (Serradiel, Cabriel, Turruchel) (Pocklington, 2010, p. 133). El Diccionario de la Real Academia Española lo traduce como: "aparejo de pesca"; en el caso de Isso, podría relacionarse con alguna actividad pesquera fluvial en el río Mundo o en la laguna de los Patos, muy cercana a este barrio. Es un topónimo de posible origen visigodo o mozárabe, y también está presente en Málaga, Canarias, Ciudad Real y Murcia, donde se localiza la Cueva de los Percheles (Mazarrón); en la provincia de Granada se advierte en Baza, Orce, El Marchal y Beas de Guadix.

Barrio de Méndez. Situado al sur de la fortaleza, se le localiza en un punto del camino de la Asomadilla al Barrio de Mendez, según aparece denominado en el plano de 1878. En las imágenes del vuelo de 1929-30, se aprecia un núcleo organizado en el encuentro de un camino secundario con el ya mencionado. $\mathrm{Su}$ morfología no ha variado sustancialmente hasta el momento actual.

Barrio de la Rambla. Está situado al sur de la fortaleza, muy cercano a la rambla del Pepino. En 1878 aparece como una alineación de casas junto a un camino y a una acequia secundaria. En la actualidad una calle une este barrio con el de Méndez. Su nombre es un hidrotopónimo directamente relacionado con la rambla junto a la que se sitúa.

Barrio de Villena. Situado al sur de la fortaleza y del barrio de Méndez, en torno a un ca- mino que, en el plano de 1878, aparece denominado como $C^{o} B^{o}$ Villenas. Ya en 1929-30 se aprecia un conjunto de casas dispersas pero cercanas, asociadas a un nudo de caminos secundarios, y esta ocupación se ha mantenido constante hasta la actualidad. Su topónimo está vinculado al municipio de la provincia de Alicante. Históricamente Isso guarda una importante relación con el Marquesado de Villena, del que dependió durante la Baja Edad Media, aunque también puede tratarse de un antropónimo, puesto que es un apellido frecuente; así por ejemplo sabemos que el licenciado Francisco de Villena Medrano ejerció de cura párroco de Isso al menos entre los años 1635 y 1655 (Esteban, Martínez, 2019, p. 22).

Barrio de Quílez. Situado al suroeste de la fortaleza, en 1878 aparece denominado como Barrio de Quiles, haciendo referencia a unas casas vinculadas a uno de los caminos principales que articulan el espacio de cultivo de Isso, cuyo trazado ya no se aprecia con claridad en el vuelo de 1929-30. En este momento aparecen una serie de casas agrupadas en relación a unas tierras de cultivo, en el espacio generado entre un brazal principal y uno secundario. En la actualidad, su extensión no ha variado más que en relación a la ocupación de una parte de la zona cultivada. Su topónimo podría hacer referencia al nombre de una de las familias que lo habitó.

Barrio de Caravaca. Situado al suroeste de la fortaleza, al pie del camino que lo une con el barrio de Bolos. En el plano de 1878 aparece denominado como barrio de Los Caravas; sin embargo, la actualización de 1951 lo nombra como barrio de la Cruz. En el vuelo de 192930 se aprecia un núcleo compacto cuya organización se ha mantenido hasta la actualidad. Dados sus diferentes topónimos, es posible que se poblara con gente procedente de la localidad murciana de Caravaca de la Cruz, o bien que su nombre sea de carácter antroponímico. A favor de esta última opción apunta el hecho de que el clérigo Luis de Caravaca, fundador en 
1604 del convento de Clarisas de Hellín, tuviera tierras de labor en Isso (Serra, 1952, pp. 1719).

Barrio de Graos. Está situado al suroeste de la fortaleza, cercano al barrio de Caravaca. En 1878 ya aparece denominado como barrio del Grao, haciendo referencia a un conjunto de casas situadas entorno a un punto del camino de la Carrasca. No parece haber tenido un desarrollo mayor del que se aprecia en 1929-30, mostrándose como un núcleo bastante compacto. Su topónimo puede estar relacionado con Grau, del latín gradus, "escalón”. También adquiere el significado de puerto artificial, casi siempre construido en madera, para cargar y descargar la mercancía que llegaba a través del mar. En este caso, dada la cercanía del barrio de Graos al río Mundo, quizás el topónimo indique la existencia allí de una pequeña instalación para el embarque de mercancías o para el control de las maderas que se transportaban por el río. Se tiene constancia de una familia en Isso con este apellido en el siglo XVI, por lo que es también posible que esta diera origen al nombre del actual barrio.

Barrio de Cerro Bartolo. Situado al suroeste de la fortaleza, cercano al Barrio del Grao. En el plano de 1878 aparece una agrupación de casas a ambos lados del Camino de la Carrasca; esta misma disposición se aprecia en el vuelo de 1929-30, en el que aparecen una serie de casas alineadas entre sí junto con algunas edificaciones dispersas. Este núcleo ha sufrido cierta transformación, habiendo desaparecido algunas edificaciones existentes en el primer tercio del siglo $\mathrm{XX}$, aunque las alineaciones preexistentes se han mantenido.

Barrio de Bolos. Está ubicado al suroeste de la fortaleza, al pie de la carretera CM-412. En 1878 es representado como un núcleo de cierta extensión desarrollado al pie del Camino de Andalucía. Es posible que este asentamiento fuese dividido al abrirse la carretera, la cual ha condicionado en cierta medida su desarrollo actual; sin embargo, siguen reconociéndose las trazas del núcleo primitivo. Este asentamiento también se conoce como barrio del Juego de Bolos o del Cerrico del Botero; ambos topónimos derivan del juego de la bolea y los bolos serranos.

Barrio de Partidores. Está situado al suroeste de la fortaleza, en torno al camino que une este caserío con el barrio de Bolos. Aunque ya aparece representado en el plano de 1878 , no hay constancia de su denominación hasta la actualización de 1951, cuando se nombra como Los Partidores. Este núcleo ya aparece consolidado en 1929-30, tratándose aparentemente de una serie de casas que se fueron agrupando en torno a un cruce de caminos. Su morfología se ha mantenido prácticamente intacta hasta la actualidad. Su nombre es un hidrotopónimo posiblemente referido a que a este punto llegan varias acequias que se dividen en diferentes ramales a su salida del núcleo.

Barrio de Peropaile. Está situado al oeste de la fortaleza, cercano a los barrios del Pino y de los Gabrieles. En el plano de 1878 se muestra la existencia de varias casas aisladas, y una de ellas aparece referida como Casa de Pero Paile; sin embargo, en 1929-30 podemos ver, además de esta casa, un desarrollo lineal de edificaciones a lo largo de un camino que une el cementerio de Isso con la Fuente del Bache, conjunto que se nombra como barrio de Pero Paile en la actualización de 1951. Su topónimo está referido a "Pedro Paile", cuya grafía correcta podría ser "Pedro Fraile". Este lugar es citado por Juan Lozano cuando señala que "se ve un cimiento de quince palmos, cuyo diámetro tiene nueve y está situado en un monte que proporciona la vista de aquel distrito" (Lozano, 1794, p. 36). Durante los trabajos de prospección en este barrio se ha identificado una cimentación de tapiería de hormigón que parece corresponder a una antigua acequia; sería necesario llevar a cabo labores de limpieza para confirmar su identificación. Por otra parte, en sus proximidades se encuentra el cerro del Pedernaloso, en cuya cima se levanta la ermita de la Cruz. En la ladera de este cerro se documen- 
tó un taller de elaboración de herramientas, fechado en el Paleolítico Medio. El topónimo Pedernaloso procede de pedernal, que también significa sílex, material muy abundante en este cerro. El yacimiento arqueológico abarca los periodos Musteriense y Eneolítico, y presenta abundante material lítico en superficie (Jiménez, Jordán, Ayala, 1995, pp. 17-22).

Barrio de los Gabrieles. Está situado al oeste de la fortaleza, junto al barrio de Peropaile. Se trata, al igual que éste, de un asentamiento lineal a lo largo del camino que une el cementerio de Isso con la Fuente del Bache. Aparece por primera vez en las imágenes de 1929-30, y referido en la actualización del plano de 1878 correspondiente a 1951, siendo denominado como barrio de Los Javieles. Actualmente, una parte de las casas ha desaparecido, conservándose algunas dispersas y un pequeño núcleo en su extremo este.

Barrio del Pino. Está situado al oeste de la fortaleza, cercano al barrio de Peropaile. En el plano de 1878 no aparece reflejado hasta la actualización de 1951; sin embargo, en la fotografía de 1929-30 ya se ve una serie de casas alineadas a lo largo de una de las acequias perimetrales. Esta ocupación se ha mantenido hasta la actualidad, aunque varias de las viviendas se encuentran en estado de abandono y semirruina.

A partir de la toponimia podemos ver cómo una buena parte de estos barrios han adquirido su nombre en referencia a los nombres de las familias principales que los habitaron (Agapito, Bartolos, Chanes, Gabrieles, Méndez, Peropaile, Quilez, etc), a la procedencia de sus pobladores (Villena, Caravaca), o a sus oficios (Canteros, Grederos, Tejera). También hay topónimos de tipo geográfico, vegetal o animal, como los barrios de Almeces, Asomadilla, Castor, Pino/os y Rambla. Por último, los tenemos de carácter hidráulico (Partidores) y antrópico (Celdicas o Casicas).
En cuanto a las casas, encontramos topónimos que hacen referencia al nombre, apellido o apodo de sus propietarios (Baltasar, Marín, Juana Rodríguez, Don Bernardino, Enrique Ramos, Andaluz, Velasco, Palacios, Carrasca, Cuqueta, Callejas); en otros casos el topónimo hace alusión al lugar en el que están situadas (Río, Rambla, La Losilla o Peña Lavada) o a elementos vegetales que las identifican (Parra o Palmera). También hay casos en los que el topónimo se refiere a la instalación en la que trabajan sus dueños (Tejera o Molino) o a su vinculación con la iglesia (Capellanía, Cura y Campana). Hay dos casos que son de especial interés:

Casa de Vínculo. Situada al sureste de la fortaleza, cerca del camino que une los barrios de la Asomadilla y Méndez. Se conserva actualmente, sin haber sufrido mayores transformaciones. Su topónimo hace alusión a la casa de la que dependen un conjunto de bienes, generalmente de tierras. En otros lugares suele nombrarse como "Casa del Mayorazgo".

Casa Grande. En este lugar se localiza un yacimiento tardorromano en el que se conservan algunas tumbas excavadas en la roca.

\section{El poblamiento medieval de la comarca}

La arqueología y la escasa documentación escrita permiten afirmar que la población más destacada de la comarca en la Antigüedad y época emiral fue, indudablemente, la emplazada en el Tolmo de Minateda, una de las ciudades que se incluyeron en el pacto firmado en el año 713 entre el comes o dux visigodo Teodomiro y el conquistador árabe 'Abd al-Azīz ibn Mūsà. A partir de ese momento parece haber sido denominada Madīnat Iyyuh, perviviendo durante casi doscientos años hasta su abandono definitivo a finales del siglo IX (Gutiérrez, 2011, p. 360).

Para fechas más avanzadas, siglos XII y XIII, el asentamiento articulador del territorio parece que fue Hellín (Falyan), un hīṣn de mediano tamaño, con una modesta fortaleza, cabeza de 
un distrito al cual pudo pertenecer Isso y otras poblaciones de menor tamaño. Actualmente se conserva una alcazaba delimitada por un recinto arruinado con unas dimensiones de $108 \mathrm{x}$ $53,5 \mathrm{~m}$, constituido por lienzos y torres de tapiería de hormigón y tapiería calicostrada. Junto a él pudo haber un caserío, pero no una ciudad; ni siquiera hay constancia de que estuviera protegido por una muralla. Tras la conquista castellana, es posible que esta fortaleza acogiera en su interior al primitivo concejo cristiano. ${ }^{11}$

No conocemos referencias seguras a Isso en los textos árabes; no obstante, podemos afirmar que ya existía en época andalusí dado que las primeras citas en la documentación castellana están relacionadas con los momentos inmediatos a la conquista de mediados del siglo XIII.

Además de Hellín, en las proximidades de Isso se localizan otras poblaciones relevantes en época andalusí que hemos examinado con cierto detalle, con el fin de poder contextualizar adecuadamente el poblamiento de la comarca en ese momento (Fig. 3).

Tobarra aparece citada en la obra del geógrafo al-Ûdrí (siglo XI), en el itinerario de Chinchilla a Cartagena. Sabemos que fue sede de un valeroso jefe local llamado Ya'qūb Ibn Jalid Al-Tubarri (Pretel, 1986, p. 16). Su castillo se encuentra en el Cerro de la Encarnación, a 679 m.s.n.m., es de planta trapezoidal, y cuenta con torreones en las esquinas.

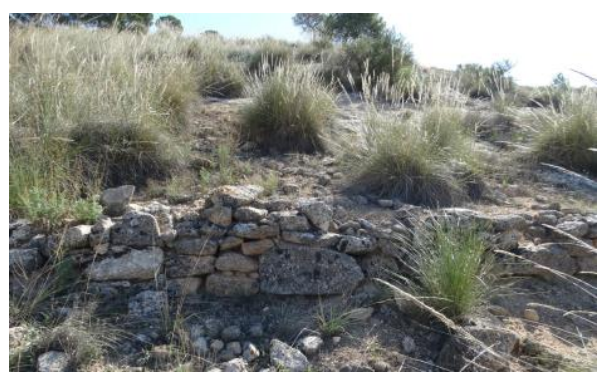

Fig. 12. Tobarra. Tramo de muralla perteneciente a la alquería de Alborajico.
Los topónimos de algunas localidades de la zona, como Albatana y Ontur, y de ciertas aldeas pertenecientes al municipio de Tobarra, como Abenuj, Aljubé, Alboraj y Alborajico, parecen tener su origen en asentamientos andalusíes (Pocklington, 2010, pp. 149, 152-153). En la aldea de Alborajico, junto al eremitorio allí existente, hallamos una alquería que conserva un tramo de su muralla, construida con mampuestos colocados de forma irregular, tomados con argamasa de cal. Esta pudo ser levantada sobre un asentamiento tardorromano o visigodo previo, según indica la cerámica que se aprecia en superficie (Fig. 12).

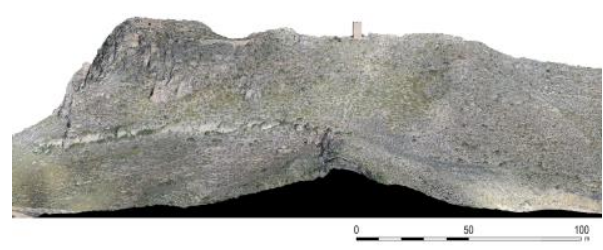

Fig. 13. Tobarra. Castillo de Sierra. Ortofotografía del alzado occidental del cerro en el que se encuentran los restos arqueológicos, elaborado a partir del modelo fotogramétrico del entorno de la fortaleza.

El Castellar de Sierra (Tobarra) era otro hiṣ̣n situado en altura. Actualmente es un yacimiento arqueológico ubicado a $5 \mathrm{~km}$ de Tobarra en dirección sureste y a 7 de Hellín en dirección noreste, y se alza sobre un cerro a 716 m.s.n.m. Su caserío se desarrolló en la ladera occidental (Fig. 13), mientras que la cima estaba fortificada con un recinto torreado, construido con mampostería tomada con mortero de cal; en el extremo occidental, una celoquia albergaba dos aljibes. Al pie del lugar se extiende una estrecha vega recorrida por el arroyo de Tobarra, sobre el que se hallaba un molino que aparece localizado en el plano de caminos de 1811 (Fig. 5). Alfonso X cedió Sierra, junto a Tobarra, en 1268 al alcaide del castillo de Albacete, con el fin de favorecer la integración de la nobleza islámica en el proceso repoblador. Este intento fracasó y fue vendido al concejo de Alcaraz mediante contrato firmado en Jerez en 1268 por el hijo del noble musulmán, Abū 'Abd Allāh (Pretel, 1998, p. 31; Carmona, Giménez, 2008), debido probablemente a que el 
lugar fue abandonado por los mudéjares que lo habitaban. Al despoblado de Sierra ya se hacía referencia a finales del siglo XVIII (Espinalt, 1778, pp. 145-146).

Con independencia de las localidades que acabamos de mencionar, hasta hace muy poco tiempo el poblamiento andalusí de la submeseta sur era un gran desconocido. La historiografía ha venido manteniendo la existencia de un paisaje de secano muy despoblado, debido al escaso interés de los andalusíes por su aprovechamiento, frente a la concentración de las poblaciones en zonas susceptibles de ser irrigadas, bien a partir de fuentes, en las zonas de montaña, o mediante caudales fluviales en las amplias vegas del Sur y del Este (Retuerce, 1995, p. 96). Sin embargo, los trabajos de prospección arqueológica que se están llevando a cabo en el área de La Mancha sudoriental por parte de José Luis Simón y Pedro Jiménez, en términos municipales colindantes con el Campo de Hellín, como es el caso del corredor de Almansa y el área sur de los Llanos de Albacete, están proporcionando una información muy rica y novedosa acerca de la evolución del poblamiento andalusí en esta región. En ese limitado espacio, los dos arqueólogos, han documentado decenas de alquerías, cuyo estado de conservación facilita, en muchos casos, levantar planimetrías generales en las que es posible registrar los perímetros de las manzanas de casas y cada uno de los edificios que las componen; incluso han conseguido, a veces, identificar su distribución interna (Jiménez, Simón, 2017, p. 218). Todo esto ayuda a defender la hipótesis de que el poblamiento y colonización de tierras desfavorecidas en esta región se desarrolló a lo largo del siglo XI, enmarcándose en un contexto de expansión comercial y agraria, como consecuencia de un despegue demográfico generalizado.

\section{Isso tras la conquista castellana}

La toma de Chinchilla, efectuada en torno al año 1242 por el infante don Alfonso y el comendador de la Orden de Santiago, Pelay Pérez Correa, dejó la frontera murciana totalmente indefensa, permitiendo a este último realizar profundas correrías en los primeros meses de 1242 en la sierra del sur, bordeando los límites del alfoz de Alcaraz. Entre sus caballeros estaba su pariente, el también portugués Gil Gómez do Vinhal, que tomó los castillos de Híjar, Abejuela, Gutta y Vicorto, y los sobrinos de éste, Gonzalo y Martín Eanes do Vinhal; es posible que entonces se ocuparan también los de Isso y Hellín, que serían entregados en tenencia al primero de ellos (Petrel, 1998, pp. 23). Otros, en cambio, consideran que tanto Isso como Hellín fueron conquistados directamente por el Infante don Alfonso "al desplazarse desde Alcaraz hasta Murcia, en abril de 1243, para hacer efectivo lo pactado" (López Serrano, 2017, pp. 807-808).

Si Tobarra capituló ante el infante don Alfonso, cabe pensar que sucediera lo mismo con Sierra, Hellín e Isso. Es muy probable que Gonzalo Eanes se limitará a dotar a los castillos de Hellín e Isso de una guarnición a la vez que se les cobraba a los mudéjares los impuestos (Pretel, 1998, p. 26).

La tenencia de la fortaleza de Isso duraría poco tiempo, pues el 31 de julio de 1251 el infante don Alfonso concedió Isso y Minateda a la reina Juana de Ponthieu: "en camio por Hiso e por Medinatea, que le tolli, e que los di a la regna donna Joana" (Petrel, 1998, p. 27). Como estas eran posesión del maestre de Alcántara fue necesario adquirirlas previamente, compensando después a la Orden de Alcántara con Alcantarilla y ciertas propiedades y molinos en la vega murciana (Díaz, 1895, p. 16).

En 1252, doña Juana de Pomthieu, uniría Isso y Minateda a Hellín, confiándolas a la Orden de Calatrava (Pretel, 1998, p. 28). El 15 de marzo de 1252, el maestre de Calatrava reconocía tener en su poder los privilegios pertenecientes a la reina Juana:

"Tres son del otorgamiento de todos los heredamientos que el Rey uso dio, et el quarto es de Felin, et el quinto es de Hyso et de Medinatea, et el sesto es de Marchena, et el septimo es de Hyso el que tenia el maestro de Alcantara" (Torres, 1969, p. 15). 
Durante aquellos años, estos territorios seguirán habitados casi exclusivamente por mudéjares, pues no había en Castilla demasiados cristianos dispuestos a venir a poblar estas tierras y los que había, preferían asentarse en zonas más ricas y fértiles como el Valle de Guadalquivir, recién conquistado.

Entre los años 1264 y 1266 se produce, en la mayor parte de los territorios de al-Andalus recién conquistados, una rebelión de los mudéjares de tales dimensiones que el rey Alfonso tuvo que solicitar ayuda a su suegro don Jaime I con el fin de sofocarla en el reino de Murcia. Aunque los habitantes de Isso y de los pueblos de su entorno eran mayoritariamente musulmanes no sabemos si se sumaron a esta sublevación, aunque todo parece apuntar a que sí lo hicieron. También desconocemos si Hellín llegó a levantarse, pues no se detecta la habitual pérdida de población que dicha rebelión tuvo en otros territorios. De hecho, llegó a convertirse en una de las villas con un mayor número de vecinos de la zona (Pretel, 1998, p. 31).

El miedo a los mudéjares pudo ser también la razón por la que Hellín recuperara su estatus de villa de realengo en fecha no precisa, y el rey le concediera algunos privilegios cuya naturaleza nos es desconocida; aunque parece que no son muy distintos de aquellos que más tarde, en 1305, le dió Fernando IV como si fueran nuevos (Pretel, 1998, pp. 186-187).

Una referencia indirecta acerca del comercio comarcal y el peligro que acechaba en estas tierras durante la segunda mitad del siglo XIII la encontramos en la obra Miraculos romançados de Santo Domingo de Silos, escrita en esas fechas por el monje Pedro Marín, en la que relata cómo fueron hechos prisioneros algunos cristianos en esta comarca (González, Molina, 2008, pp. 119-124, 126). El caso que más nos interesa es el de un buhonero de Isso llamado Juan:

"En la era sobredicha, vino a Santo Domingo don Johán, vn buhón morador en Yso, aldea de Helín, e dixo que un miércoles de nouienbre, era de mill e CCC e XXI [1283] annos, que yua a comprar grana a Socobos, vn castillo de moros que era Orden de Vclés, e pasando por la alcantariella del río Segura, fallóse con Mahomat Abuscar, almocadén de Vera, que aduçía consigo XII peones moros, e captiuó a este don Johan e leuólo a Velez el Blanco e metiólo en vna cárçel, e yogó ý V días" (González, Molina, 2008, p. 119).

Hellín perdería su estatus de villa de realengo antes de la muerte de Alfonso X (1284). En la década de 1260, su hermano el infante Manuel había acumulado un gran señorío que venía extendiéndose desde su primitivo enclave en el levante peninsular hasta Almansa; y en la siguiente década ya se había interesado por Yecla y Hellín, e incluso por los términos de Chinchilla, Jorquera y por la villa de Ves. Es posible que Hellín también fuera cedido por el rey a su hermano el infante Manuel, pues sabemos que éste le confirmó sus fueros y cuantos privilegios tenía otorgados con anterioridad. Isso también acabó integrado en el Señorío de los Manuel, como lo prueba un documento de 1284 por el que el obispo de Cartagena reclamaba ante el rey las usurpaciones de rentas por parte de vasallos de don Manuel, citando a un tal "Fruela alcayde de Hellin et de Ysso" (Pretel, 1998, p. 4; 2008, p. 211).

Tras la invasión aragonesa del reino de Murcia, don Juan Manuel entregó Isso y Hellín en 1305 al rey Fernando IV de Castilla, el cual confirmó los fueros, usos, costumbres, privilegios, cartas de mercedes y franquezas otorgadas por su abuelo, el rey Alfonso X:

"Sepan quantos esta carta bieren commo yo Don Fernando [...] porque la villa de Hellín e Isso son mias por talante que e de facerles muncho bien e muncha merce a los que y son agora moradores [...], otorgoles e confirmoles todos sus fueros [...] que an del rey don Alffonso mio abuelo e del rey don Sancho mi padre que Dios perdone e del ynfante don Manuel e de don Juan su hijo quando estos lugares eran suyos, que lo ayan e lo usen dello bien e cunplidamente asi commo mejor lo ovieron e lo usaron fasta aquí. E porque entiendan que hera boluntad de les fazer mas bien [...], porque sean mejor poblados e mas rricos para mio seruiçio. Quito a todos los vezinos que son moradores en Fellin e en Isso [...] que non den 
pecho ninguno que acaezca que me ayan a dar en qual quier manera que sea por los heredamientos e casas que han en estos lugares sobredichos" (Pretel, 1998, pp. 186-187).

En 1311 volvieron a incorporarse al señorío de los Manuel, esta vez de forma definitiva. Hacia 1340 don Juan Manuel ordenó en su testamento entregar los castillos de Isso, Hellín y Tobarra, entre otros, a su hija Constanza, en fianza y garantía de su dote y herencia, los 800.000 maravedís que debería darle el heredero don Fernando Manuel cuando el padre falleciese. Pero pagada esta, el castillo de Isso, al igual que los otros, debía reintegrarse al mayorazgo de la casa Manuel (Pretel, 1998, pp. 50-51).

La llamada "Guerra del Marquesado" que enfrentó a los Reyes Católicos y al marqués de Villena Diego López Pacheco, y que finalizó en 1489, tuvo graves consecuencias para este último, cuyo vasto territorio pasó en gran parte a manos de la Corona bajo la denominación de Gobernación del Marquesado de Villena, con capital en la villa de San Clemente (Cuenca).

En 1586 esa unidad administrativa se dividió en dos corregimientos autónomos: al norte el que fue denominado como "Corregimiento de San Clemente" o "de las Diecisiete Villas", que mantuvo a la villa de San Clemente como residencia del corregidor; y al sur, el de "Chinchilla y Villena", también conocido con el nombre de las "Dos ciudades y Nueve Villas", que tuvo su capitalidad en la ciudad de Chinchilla. En este último se integraron todas las localidades pertenecientes al Reino de Murcia y las dependientes de la diócesis de Cartagena, incluida Hellín con las aldeas de Isso, Cancarix y Agramón.

El corregimiento de Hellín se creó en 1665 e incluyó inicialmente la villa de Hellín y las aldeas de Isso y Cancarix. A partir del siglo XVIII se incorporaron las poblaciones de Agramón, Jumilla, Ontur, Albatana y Tobarra (Molina Puche, 2005, pp. 65-66).

\section{Demarcación eclesiástica de Isso}

En el ámbito eclesiástico, la aldea de Isso quedó incorporada a la jurisdicción de la Orden de
Santiago, por lo que inicialmente se mantuvo exenta de autoridad episcopal, aunque por poco tiempo, pues tras depender fugazmente de las órdenes de Calatrava y Alcántara (Pretel, 2000, p. 58), pasaría a la Corona en 1252 y, teóricamente, al obispado de Cartagena, que había sido "restaurado" por el papa Inocencio IV dos años antes. En ese momento, Hellín se convertirá en cabeza de una vicaría de la que pasarán a depender las aldeas de Isso, Minateda, Calasparra, Jumilla y Tobarra (Pretel, 1998, p. 33).

La población cristiana debió de ser minoritaria entre los años que van desde la toma de la aldea hasta la rebelión mudéjar de 1264, puesto que el Tratado de Alcaraz permitía que los habitantes musulmanes continuaran practicando su religión y costumbres. Por ello, cabe pensar que la comunidad mudéjar de Isso, si existió, debió de mantener su identidad cultural y sus lugares de culto. A pesar de su posible reducción debido a la emigración, es muy probable que la población islámica siguiera siendo mayoritaria con respecto a los repobladores, pues el obispado de Cartagena tuvo serios problemas en las siguientes décadas para cobrar el diezmo en éste y otros lugares como Hellín, lo que llevó a los obispos a formular reiteradas quejas ante el rey en la segunda mitad del siglo XIII (González Arce, 2008, p. 98).

En 1274, un año marcado por la crisis derivada de las malas cosechas de cereal, el obispo don García Martínez elevó una queja a Alfonso X, ante el impago de los diezmos. El monarca, a instancias del portero real, mandó detener a Pedro Esteban y otros cogedores que se negaban a entregar el diezmo a los encargados por parte de la Iglesia. Su detención no parece que acabara con el problema, pues unos años después, en 1284, el obispo don Diego Martínez reclama ante el rey Sancho IV las usurpaciones de rentas por parte de vasallos de don Manuel, además de quebrantar sus casas. El rey manda que se entregue el diezmo demandado y se reparen los daños:

"Sepades que don Diego, obispo de Cartajena, se me querelló que Sancho Sánchez, alcayde de Xorquera, et Fruela, alcayde de Hellín et de 
Yso, et el alcayde de las Pennas de San Pedro et algunos otros aicaydes et omes de los concejos toman sus diezmos et lo suyo et desapoderaron dellos a sus omnes de quel quebrantaron sus casas [...]. Onde vos mando firmemente que de aquellos que se el obispo querellase o su oficial o su mayordomo que fagades luego entregar todo quanto le tomaron et emendar el danno [...]" (Pretel, 1998, p. 41; 2008, p. 211).

En 1353, Pedro I reconocía a la iglesia de Cartagena su derecho, concedido en tiempos de Fernando IV, a cobrar la renta de Isso, Hellín y Molina (Pretel y Rodríguez, 1998, p. 132).

Posteriormente, el libro Fundamento de la Santa Iglesia [...] de Carthagena del Obispo don Diego de Comontes (1446-1459) en el capítulo relativo a los diezmos, señala que:

"De los diezmos de Tobarra, con Isso, se facen otrossi tres tercios, el uno es de los Señores Obispo, y Cabildo, y partiendo por medio; el otro es del Beneficio, y Prestamo de allí, de el qual las dos partes son del Rey, y la otra del Terçcuelo dende. Las primicias de Tobarra entran en esta particion, cá pertenece insolidum á los dichos Señores Obispo y Cabildo, y partencelas por medio, no dando de ellas al Clerigo dende parte alguna" (Torres, Molina, 2009, p. 38).

La importancia de la ermita de Isso en 1576 se evidencia en Las Relaciones Topográficas cuando se la menciona inmediatamente después de la única iglesia parroquial que hay en Hellín:

"En la dicha uilla de Hellin, demás de la yglesia parroquial, ay vna hermita de señor Santiago [...]" y otras ocho más. A continuación se indica que Tobarra es "bicaria de la villa de Hellin y que en esta villa ay vn benefiçio curado, que suele comunmente rrentar treçientos ducados, y ay otro prestamo, que bale trescientos ducados, y que tiene por anexos el diezmo de Yso, termino e juridicion de la villa de He1lin" (Carrillero, et al., 2014, p. 129, 210).

Llama la atención que para estas fechas Isso todavía no disponga de parroquia propia, teniendo en cuenta que tiene un cinturón de pequeños asentamientos dispersos por su vega.
Además, sorprende el hecho de que, perteneciendo a la jurisdicción de Hellín, dependiera de la parroquia de Tobarra, distante unos 15 $\mathrm{km}$. Nada de lo dicho se puede entender si el motivo no es otro que la falta de población que en el último cuarto del siglo XVI parece que todavía era escasa. En el año 1630 la antigua ermita ya aparece con la categoría de parroquia, desconociéndose cuándo alcanzó este rango. No obstante, continuó dependiendo de la iglesia de Tobarra, que a su vez lo hacía de la Vicaría de Hellín. Finalmente, la iglesia de Isso fue segregada de la de Tobarra por la distancia existente entre ambas poblaciones, aunque su párroco mantuvo el derecho de presentación sobre este beneficio (Irigoyen, et al., 2002, p. 230).

El Archivo diocesano de Albacete conserva el libro parroquial de defunciones de Isso que comienza en 1670. Otros documentos procedentes de los Protocolos Notariales, en concreto en el testamento de Jerónima de Ortín, de 1644 vienen a confirmar este cambio de categoría:

"De las misas $[\ldots]$ en la Parroquial de Santiago, donde soy feligresa. [...] A Honor y Reverencia de Apóstol Santiago, seis misas rezadas y estas se digan en su Iglesia de este heredamiento de Isso y por el cura de su Parroquial. [...] Al licenciado Francisco de Villena, cura de la parroquial del Señor Santiago de este heredamiento de Isso" (Esteban, Martínez, 2019, p. 22).

En el Atlante Español (1778) se dice que "la parroquia de Iso es de nueva construcción, de la que son feligreses doscientos vecinos". La mención a "nueva construcción" hace referencia a la remodelación o ampliación de este templo en el siglo XVIII (Fig. 17). El mantenimiento del templo corría a cargo de los patronos de las capillas, de las limosnas de los feligreses y de los diezmos según aparece en las respuestas generales al Catastro de la Ensena$d a$ de 1755:

"En la huerta del Heredamiento de Yso sujeto a este término hay una porción de tierras acotada, otros Diezmos se dividen también por tercias partes, con la orden referida entre $\mathrm{Su}$ 
Majestad (2/3) y Fábrica de la Parroquial de este Heredamiento (1/3) una, la Dignidad y Cabildo (Obispado de Cartagena) otra y la restante por mitad entre el cura y otro beneficiado de la misma Parroquial de Yso [...] Y el Boto de Santiago lo paga cada labrador, siempre que tenga un par de labor".

Nipho solo aporta el nombre del párroco y el número de feligreses que tenía la parroquia: "Y Cura de la parroquial de Iso, titulo de Santiago, de la que son Feligreses doscientos vecinos, es Don Francisco González Caravaca" (Nipho, 1770, p. 293). Este clérigo también es citado por el canónigo Lozano como "cura de Isso" y propietario de una colección de monedas antiguas aparecidas allí (Lozano, 1794, p. 37).

Con la creación de la Diócesis de Albacete en 1949 todo el territorio de esta provincia, que dependía hasta ese momento de la de Cartagena, se incorporó al nuevo obispado estructurado en 12 arciprestazgos, entre los que se cuenta el de Hellín con la parroquial de Isso.

\section{El caserío de Isso}

El siguiente análisis del núcleo de población de Isso lo hemos realizado a partir de la fotografía aérea obtenida en el conocido vuelo de Ruiz de Alda de 1929-30 (Fig. 14). Lamentablemente, no tenemos un documento fotográfico más antiguo que nos permita acercarnos a la imagen tradicional inalterada de este caserío, pues las obras de regularización y ensanche del camino histórico que comunicaba Hellín con Elche de la Sierra para esas fechas ya estaban hechas, con la consiguiente demolición de algunas agrupaciones de casas y con la apertura de una nueva calle diseñada con función de carretera.

Para explicar la génesis y la planta de este núcleo de población es necesario tener en cuenta los siguientes elementos: los caminos históricos que desde Hellín y desde la Fuente pasan por Isso en dirección Elche de la Sierra, la acequia de la Fuente y su camino anexo, y el pequeño promontorio sobre el que se alzó la fortaleza.
El acueducto por donde discurre la acequia de la Fuente de Isso flanquea a la fortaleza y a todo el caserío por su frente occidental, a una distancia de unos $50 \mathrm{~m}$ (Fig. 10). Tras pasar por el molino cruza los accesos a Isso que vienen desde el oeste, creando un obstáculo que fue necesario sortear con un puente que en la segunda mitad del siglo XX fue ocultado por la carretera CM-412 que une esta pedanía con Elche de la Sierra (Fig. 15). ${ }^{12}$

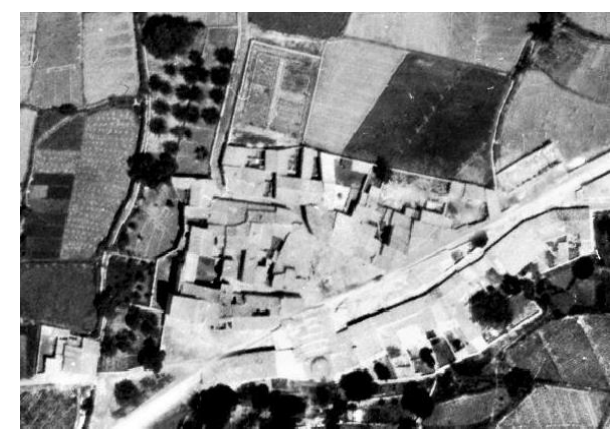

Fig. 14. Isso. Ortofotografía de su caserío,obtenida a partir del vuelo aerofotográfico de Ruiz de Alda (1929-1930).

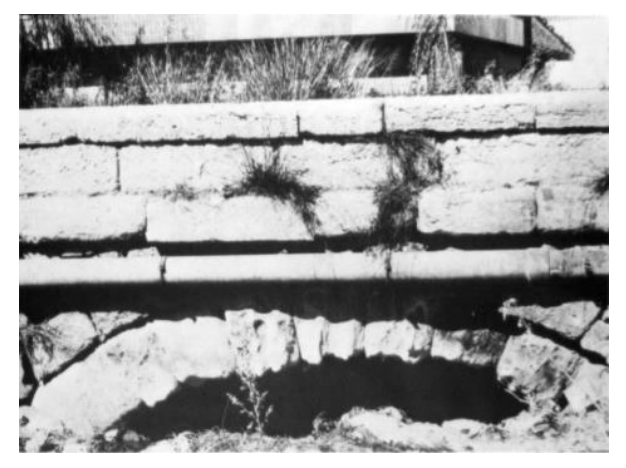

Fig 15. Isso. Puente que estaba situado a la salida de Isso en dirección a Elche de la Sierra. Foto publicada en "Los puentes romanos de Isso" (Baquero et al, 1983, p 56).

El caserío tradicional, que llegó bien conservado a la segunda mitad del siglo XIX, estuvo constituido por tres agrupaciones de casas articuladas en torno a la plaza. Hablamos de agrupaciones de casas y no de manzanas, pues en sentido estricto no podemos considerarlas co- 
mo tales dado que las calles no las circundan por todos sus lados (Fig. 16).

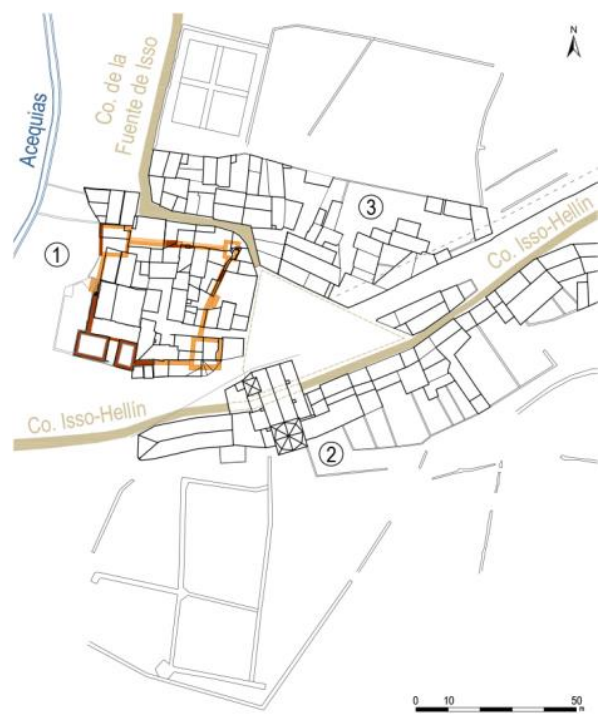

Fig. 16. Isso. Su caserío en los años 1929-30. El levantamiento se ha realizado a partir de la ortofotografía obtenida del vuelo de Ruiz de Alda.

Agrupación $\mathbf{n}^{0}$ 1. Se encuentra al oeste de la plaza y ha llegado al siglo XXI compuesta por unas quince viviendas: seis de ellas se construyeron en el interior de la fortaleza mientras que el resto se adosaron a la muralla por el exterior (Fig. 16). Su estado de conservación es malo en la mayoría de los casos, debido a que buena parte de ellas ya no está habitada y al menos dos fueron demolidas hace más de 25 años. El abandono de sus solares durante tanto tiempo está creando serios problemas en las medianerías de las casas que los circundan. El ensanche de la carretera en la década de 1980, a su paso frente a la iglesia de Isso, obligó a demoler las casas del ángulo sureste de la agrupación y la gran torre de esquina que allí se conservaba (Figs. 21-23).

$\mathrm{Su}$ origen hay que buscarlo en la fortaleza andalusí que allí hubo, cuyos restos se encuentran conservados entre las casas que forman este barrio. La planta de esta agrupación de casas es de tendencia cuadrangular debido, en gran medida, a la forma de la fortaleza que hay en su interior. Está construida en su mayor par- te sobre una plataforma natural rocosa situada a una cota de 493 m.s.n.m. Su elevación, respecto a los espacios circundantes, es apenas apreciable en la actualidad.

La formación de este barrio habría que situarla en una fecha imprecisa a partir del momento en el que la fortaleza perdió su valor poliorcético, nunca antes de la caída del reino nazarí de Granada a fines del siglo XV. Es muy probable que a finales del siglo XVI se iniciara la construcción de las primeras, tanto de las levantadas dentro del recinto como de las que se edificaron en el exterior, adosadas a la muralla. Con independencia de la fecha exacta en la que se iniciaron las obras, es evidente que la fortaleza terminó transformándose en un barrio compacto, delimitado en tres de sus flancos por dos calles y una plaza. Para acceder a las seis viviendas construidas en el interior, fue necesario habilitar un acceso que se inició en la plaza y que hoy conocemos como calle del Castillo (Fig. 18); su trayectoria es en ángulo recto y presenta en su primer tramo una pendiente ascendente que permite salvar la diferencia de cota que había entre el interior y el exterior de la fortaleza. No parece que esta calle se originara a partir de un antiguo acceso a la fortaleza, más bien creemos que se habilitó para dar servicio a las casas allí construidas. De este grupo de viviendas, la única que ha mantenido la comunicación directa del interior de la fortaleza con el exterior ha sido la principal (parcela 1), que desde 1616 fue residencia de los Valcárcel. La parcela 2, además de abrirse a la calle del Castillo, tiene comunicación con un huerto de su propiedad que está adosado a la fortaleza por el oeste.

El frente occidental de la manzana ha sido el único en el que no se han construido casas adosadas a la muralla por el exterior (Fig. 18). Todo parece indicar que no se quiso afectar, ni a la servidumbre de paso que debió de tener la acequia, ni a la valiosa huerta que hay entre la fortaleza y el acueducto. En este frente se ha comprobado el completo desinterés que se tuvo por conservar la muralla, pues tanto en la 
parcela 2 como en la 14 fue eliminada junto con la torre de esquina noroccidental, pudiéndose apreciar el vacío que han dejado, de modo que se utilizó el basamento de dicha torre para cimentar el núcleo occidental de la casa perteneciente a la parcela 14 .

Agrupación no 2. Se sitúa al sur-sureste de la plaza, bordeando por el sur el antiguo camino que une Hellín y Elche de la Sierra (Fig. 16). Su forma alargada se debe a su adaptación a esta vía de comunicación que se transformó en calle y en plaza al introducirse en el núcleo urbano de Isso. En la fotografía aérea se aprecia que se trata de un frente alineado de parcelas que tienen dos partes bien diferenciadas: la delantera está edificada y corresponde con la casa que se abre a la calle, mientras que la trasera es el huerto cercado que cada vivienda tiene como anexo.

A diferencia de la zona edificada que presenta una línea homogénea a la que se adaptan todas las fachadas, los huertos traseros no están alineados ni se abren a calle alguna. De entre todos ellos destaca, por sus grandes dimensiones y por su jardín de crucero, el que estuvo asociado a una gran vivienda de carácter urbano, situada en el extremo occidental, junto a la iglesia parroquial ${ }^{13}$. Los huertos situados al este de la iglesia son mucho más reducidos y conforman un bloque homogéneo en el que sus tapias traseras se alinean formando un frente común. Esta regularidad sugiere un sistema de lotización parcelaria que sería muy interesante estudiar en un futuro.

La línea homogénea, con ciertas sinuosidades, generada por las fachadas de todas las casas, parece ser el fruto de la adaptación de todas las parcelas a lo que fue el antiguo camino. La única que rompe la homogeneidad de todo este frente es la iglesia, cuya ampliación hacia el noroeste supuso, por un lado, la invasión del camino y su desplazamiento al pie de la torre sureste de la fortaleza, y por otro, el cierre y la mejor definición del espacio triangular de la plaza. Es de suponer que la primitiva ermita debió de tener su fachada alineada con el ca- mino, al igual que sucede con las casas vecinas.

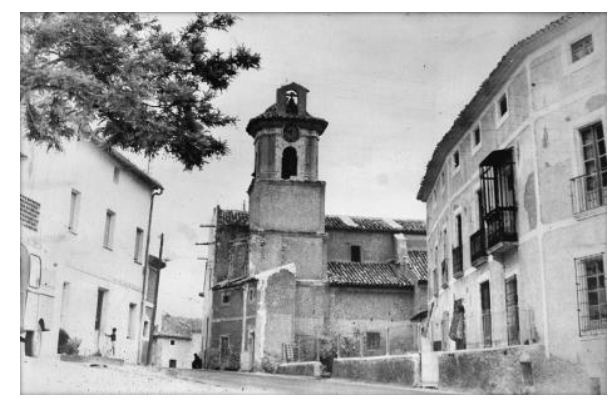

Fig. 17. Isso. En el centro la iglesia parroquial de Santiago Apóstol. (Jesús López).

Lamentablemente, desconocemos la fecha en la que se extendió en esta dirección, pues hay indicios que indican que la gran reforma de la iglesia, acaecida en el siglo XVIII, debió de centrarse en el crucero y en el presbiterio. Tras la reforma barroca, el templo presenta una nave de planta rectangular cubierta con bóveda de medio cañón apoyada en los contramuros, entre los cuales se disponen las diferentes capillas, que albergan enterramientos señoriales. La cabecera, de planta cuadrada, está cubierta con cúpula de media naranja que parece corresponder a una fase posterior. Su orientación hacia el sur-sureste, en principio, podría parecer extraña pues canónicamente lo correcto sería que el templo siguiera la dirección esteoeste. Esta "anomalía" se incrementa cuando comprobamos que la cabecera de la iglesia, cubierta con una cúpula voluminosa, se construyó contra ladera en el siglo XVIII y para ello fue necesario hacer unas infraestructuras importantes que permitieran mantener la misma cota de suelo en todo el interior del templo. Con estos datos se podría defender la hipótesis de que la antigua ermita reutilizó una mezquita, cuyo muro de quibla estaría orientado al sur-sureste. Esta hipótesis parecería más verosímil si la disposición del templo no coincidiera con la de todas las parcelas que conforman este frente de casas. y que parece generada por el trazado del antiguo camino y no por la presencia de una supuesta mezquita. 
Agrupación no 3. Se sitúa al noreste de la plaza (Fig. 16). Sus límites históricos han quedado marcados por los dos caminos ya mencionados y la fortaleza. Lamentablemente, este ha sido el caserío más alterado durante los siglos XIX y XX. Con anterioridad, esta agrupación de casas estuvo separada de la $\mathrm{n}^{\circ} 2$ por una estrecha calle, denominada Pardo, que correspondía al camino histórico que unía Hellín con Elche de la Sierra.

Fue en el último cuarto del siglo XIX cuando en su extremo oriental se abrió la callecarretera que hoy conocemos, desgajando un grupo de casas que terminó siendo derribado en los inicios de la década de 1980. Además de las demoliciones, la apertura de este vial generó una alteración importante de las fincas afectadas, debido a que las que fueron mutiladas se recompusieron al edificar casas con fachada abierta a la nueva calle.

Si observamos en la foto aérea de Ruiz de Alda las zonas no alteradas (Fig. 14), situadas más al oeste, comprobaremos que existió un modelo de implantación parcelaria, parecido al que hemos analizado en la agrupación $\mathrm{n}^{\mathrm{o}} 2$, en donde las casas abiertas a la calle de la Fuente y a la plaza tienen sus huertos traseros compartiendo una misma alineación de trazado rectilíneo que va de este a oeste. En este panorama bastante homogéneo observamos una "anomalía", situada en el extremo occidental, en forma de huerto de crucero ${ }^{14}$, semejante al que vimos en el extremo occidental de la agrupación $\mathrm{n}^{\circ} 2$ (Figs. 14 y 16).

La plaza. Su forma se debe en gran medida, a la confluencia de los dos caminos ya mencionados frente al castillo, cuyo emplazamiento evidencia la función de control que tuvo sobre ellos.

Si eliminamos la ampliación de la iglesia hacia el norte, comprobaremos que allí existió un gran espacio libre, parecido a un triángulo isósceles, cuyo lado mayor, el meridional, sería el trazado del camino principal que une Hellín con Elche de la Sierra. El lado occidental de la plaza lo consolidó la presencia de la for- taleza, mientras que el oriental lo podemos considerar continuación del camino de la Fuente. No cabe duda del importante papel que debió de jugar este espacio como lugar de reunión, celebración y comercio durante toda la Edad Media, máxime si reparamos en que el territorio de Isso parece que tuvo una población muy dispersa, agrupada en pequeñas alquerías conocidas tradicionalmente con el nombre de barrios. Resumiendo, podemos decir que de todos los espacios que componen el núcleo de población de Isso, la plaza es el único que, por su génesis, forma y función, podemos considerar enteramente urbano.

Tras analizar el caserío tradicional de Isso, concluimos afirmando que no hemos identificado rasgos morfológicos que permitan defender que junto a la fortaleza andalusí de Isso hubo una población antes de la conquista castellana, lo que obviamente no significa que no existiera y que haya desaparecido todo rastro de ella. La agrupación $n^{\circ} 1$ se formó claramente en la Edad Moderna, una vez que la conquista de Granada hizo desaparecer el peligro que justificaba la presencia de la fortaleza; mientras tanto, las otras dos agrupaciones presentan rastros claros de un modelo de parcelación orientado a la colonización, que está en función de un tipo de casa con patio en las traseras que nada tiene que ver con el arquetipo de vivienda de patio central andalusí.

\section{La fortaleza: fuentes escritas}

La elección del lugar exacto en el que se construyó la fortaleza no se puede explicar sin el promontorio rocoso sobre el que se eleva, de manera que un accidente natural facilitó las condiciones defensivas de un edificio que dominaba un territorio en el punto por donde pasa una importante vía de comunicación que une el Levante con Andalucía central, así como una de las acequias principales que riegan la huerta de esta población, la acequia de la Fuente.

Aunque el recinto castral desapareció en buena parte, fagocitado por las viviendas que allí se 
construyeron, algunos restos monumentales han llegado visibles hasta nuestros días. No obstante, podemos hacernos una idea bastante aproximada de la fortaleza gracias a las fuentes escritas, corroboradas por los datos arqueológicos obtenidos en 2019. Toda esta información, que será analizada en los siguientes epígrafes, apunta a la existencia de un recinto de planta de tendencia rectangular, con una gran torre en cada esquina y, posiblemente, otras de menor tamaño en el centro de los frentes oeste, norte y este de la muralla (Fig. 18).

La descripción de la fortaleza más antigua que conocemos forma parte de las Relaciones Topográficas (1576):

"[...] e que en la guerta de Yso, que esta media legua desta villa [de Hellín] ay un castillo de torres fechas con tierra, con costra de argamasa el qual dicho castillo es tan antiguo que asi todo esta caydo e derribado, e que en el dicho castillo no a avido ni ay armas ningunas".

"[...] como media legua de la dicha villa [de Hellín] estan las guertas de Yso e fuente e agua della, con que se riega y que en la dicha parte y eredades ay un castillo y en el quedan algunas torres buenas e paresçe ser muy antiguas e que en la dicha parte se han hallado e hallan de cada dia edificios de casas, las quales estan caydas, e solamente se hallan los cimientos, por los quales paresçe son tan antiguas que no ay memoria mas de que se dize que fue lugar muy antiguo" (Carrilero, et al., 2014, pp. 113-131).

En 1796, el canónigo Lozano describe el mismo recinto:

"El castillo inmediato a la plaza conserva lienzos de muralla, cuya longitud de Norte a Sur tiene 70 varas $[58,51 \mathrm{~m}]$, como $55[45,97 \mathrm{~m}]$, su latitud de oriente a Ocaso. La fábrica de argamasa, sus cimientos con 9 palmos de diámetro $[1,88 \mathrm{~m}]$; y cuatro torres en los ángulos, llaman demasiado la atención. [...] También con actos subterráneos a distancia de 200 pasos, respecto del Castillo. La mina es profunda, y pueden caminar por ella dos hombres en línea. Parece dirigirse al Castillo semejante conducto [...]" (pp. 34-43).
Los autores de los siglos XIX y XX suelen recoger la información aportada por las Relaciones Topográficas y por el canónigo Lozano, sin aportar datos nuevos (Ceán, 1832, p. 84; Madoz, 1847, p. 165; Blanch, 1866; p. 45; Amador, 1912, pp. 924-928).

\section{La fortaleza: análisis de su materialidad}

Las referencias escritas que acabamos de mencionar nos obligaban a realizar un estudio pormenorizado de todas las casas del barrio para tratar de identificar posibles restos ocultos de la fortaleza. Para ello, fue necesario acometer su levantamiento planimétrico, lo cual permitió, además de localizar varias medianerías en las que se conservaban los restos de la antigua muralla, identificar claramente líneas estructurales relacionadas con el recinto amurallado.

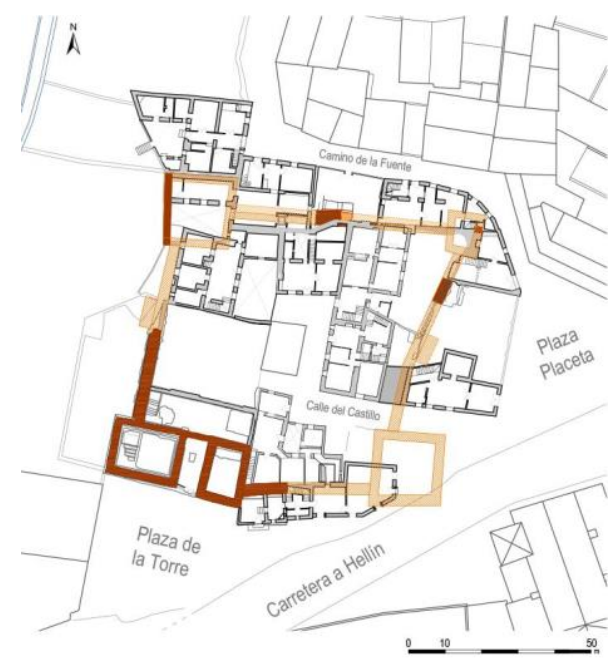

Fig. 18. Isso. Planta del barrio de la fortaleza, con indicación en color anaranjado de los restos arqueológicos (color más oscuro) y de la hipótesis del trazado del recinto amurallado con sus torreones (color más claro). Planimetría elaborada a partir del levantamiento arquitectónico de las casas.

La planta en la que hemos restituido el perímetro de la fortaleza dibuja una figura cuadrangular con grandes torres en las esquinas (Fig. 18), cuyos vestigios mencionaba el canónigo Lozano en el siglo XVIII. En cuanto a la anchura 
este-oeste del castillo que cita Lozano (55 varas) coincide con lo que nosotros hemos podido comprobar; sin embargo, el eje norte-sur rebasaría en 20 varas la cifra proporcionada por el canónigo.

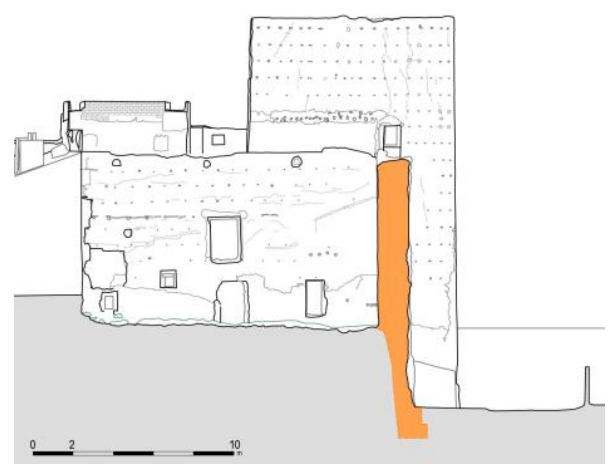

Fig. 19. Isso. Sección este-oeste de la fortaleza trazada por el patio de la parcela $\mathrm{n}^{\circ} 1$. La muralla, con relleno marrón, permite observar la diferencia de cota $(4,00 \mathrm{~m})$ entre el interior y el exterior del recinto.

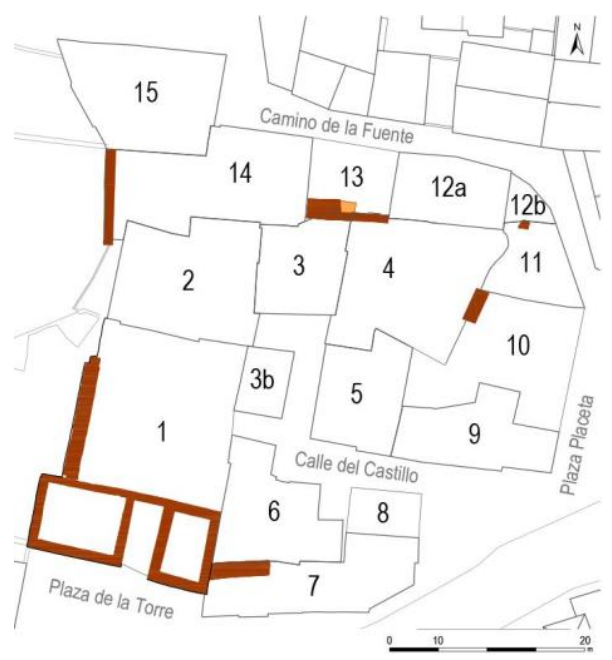

Fig. 20. Isso. Barrio de la fortaleza. Numeración de las 15 parcelas que lo componen. En color se representan los restos de la fortaleza identificados: lienzos y torres (marrón), y forro de la muralla (naranja).

Las grandes estructuras emergentes, junto a las encontradas como resultado de las prospecciones arqueológicas que hemos realizado en 2019, constituyen las evidencias materiales a partir de las cuales vamos a intentar describir la fortaleza: contorno, elementos, funcionamiento, evolución, etc.

Las casas se construyeron adosadas a la muralla, por el exterior y por el interior del recinto, quedando una clara línea divisoria en el parcelario, consecuencia tanto del salto topográfico entre la zona intramuros y extramuros, como de la preexistencia de la muralla que, en la mayoría de los casos, ha desaparecido.

Las secciones de las viviendas han permitido verificar que las construidas intramuros estaban a una cota más alta que las que se adosaron a la muralla por el exterior (Fig. 19). Esta diferencia de altura, comprobada en todas las parcelas, responde al aprovechamiento de la topografía que se hace siempre a la hora de diseñar el perímetro de una fortaleza, con el fin de que esta se encuentre más elevada que el territorio circundante. En el caso de Isso, se ha detectado que se construyó aprovechando una muela rocosa poco elevada, que actualmente se encuentra enmascarada por las construcciones posteriores y por el propio castillo. En la mayoría de los lugares en los que se ha analizado la base rocosa, sobre la que se levantó el perímetro amurallado, hemos corroborado que antes de construirlo se hizo un recorte artificial de la plataforma rocosa creándose en algunos puntos un auténtico escalón, en unos casos completamente vertical (Fig. 24) y en otros inclinado (Fig. 28). El análisis del parcelario y de los muros de las viviendas ha permitido constatar la existencia de algunos tramos de muralla reutilizados como una gruesa medianería en la que se han apoyado las viviendas construidas extramuros (Fig. 30).

Con el paso del tiempo, los propietarios de estas casas, con el objetivo de ganar superficie habitable, llevaron a cabo una progresiva destrucción de la muralla hasta el punto de hacerla desaparecer. Esta invasión de su espacio explica en parte la irregularidad de estas viviendas caracterizadas por presentar una arquitectura popular construida con materiales pobres.

En el frente septentrional de la fortaleza, al estar las viviendas construidas a una cota más baja, fue posible excavar pequeñas cuevas en 
el sustrato rocoso sobre el que se apoya la propia muralla (Figs. 26 y 27). Con independencia de que algunos de sus restos se hayan conservado o no como medianería, su trazado ha dejado una huella indeleble en el parcelario.

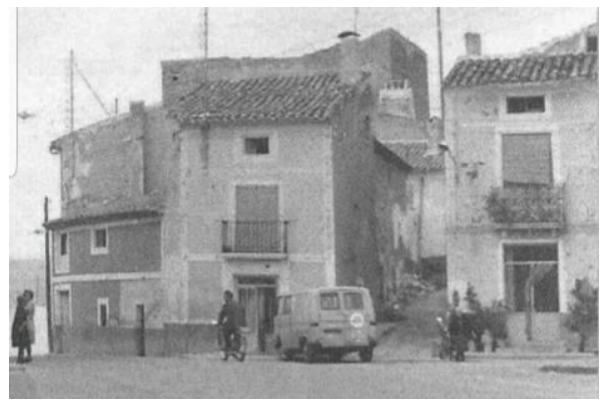

Fig. 21. Isso. Plaza de la Iglesia. En el centro se ve una casa (parcela $\mathrm{n}^{\mathrm{o}} 8$ ), actualmente demolida, y a su derecha el inicio de la calle del Castillo. (Pilar Pérez, década de 1960).

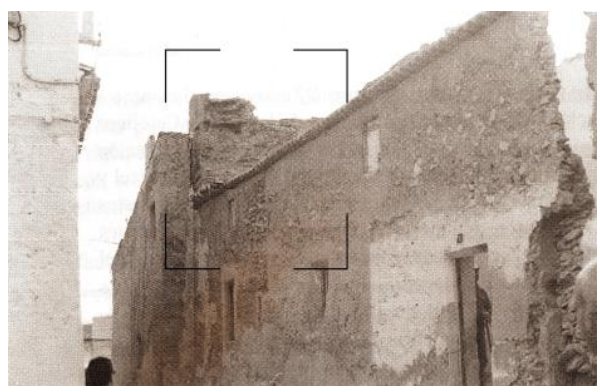

Fig. 22. Isso. Calle del Castillo. Vista desde el oeste. A la izquierda la casa demolida que se abría a la plaza de la Iglesia (parcela $n^{\circ} 8$ ). Detalle de la esquina del torreón sureste. Foto publicada en Historia de Isso (Losada, 1999, p. 22).

Por otra parte, tenemos evidencia del uso de tapiales en la construcción de la fortaleza. Estos sirvieron para dar forma a diferentes materiales (tierra, argamasa y mampuestos) que fueron ordenados y compactados dentro de los límites impuestos por los encofrados. La elección de los materiales y la manera de disponerlos dieron lugar a distintos tipos de tapia (López Martínez, 1999). Antes de continuar queremos explicar el significado preciso de los términos que vamos a utilizar al describirlas a lo largo de este artículo:
"Tapial" para referirnos al tablero característico con que se encofran las tapias. Está formado por un conjunto de tablas dispuestas horizontalmente, unidas con unos listones, también de madera, dispuestos verticalmente y clavados a las tablas, las cabezas de estos clavos, normalmente, sobresalen de la superficie del tapial.

"Tapia" para el muro, o la parte de muro hecha de una vez con la ayuda del tapial utilizado como cajón. Tanto el tapial como la tapia fueron empleados como unidad de medida para describir, proyectar, o encargar una construcción.

"Tapiería" para denominar el tipo de fábrica o técnica constructiva, así como al conjunto de muros.

Ninguno de los tres vocablos hace referencia a un material, sino a la técnica que servirá para convertir los materiales en un elemento constructivo, fundamentalmente muros. Hemos utilizado el término "mampostería encofrada" para los casos en los que existe alguna duda sobre si los mampuestos fueron colocados, o no, con los métodos de la tapiería.

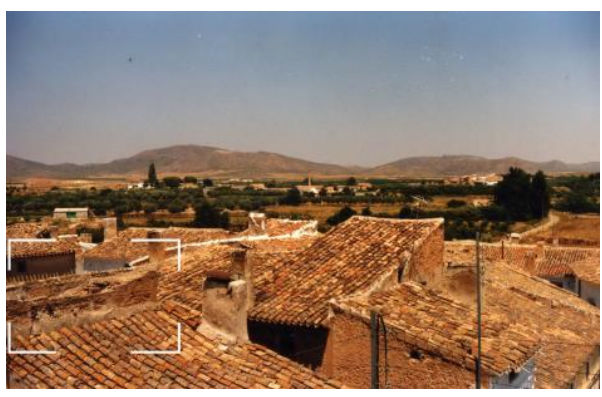

Fig. 23. Isso. El barrio de la fortaleza visto desde el campanario de la iglesia. En primer plano, a la izquierda se aprecia el tejado de la casa demolida (parcela $\mathrm{n}^{\circ} 8$ ) y los restos del torreón sureste. (María Pilar Hermosa Rodríguez).

Hecha esta breve digresión, retomamos el análisis material de la fortaleza y para ello vamos a reparar en varias fotografías que documentan estructuras medievales que fueron destruidas en la segunda mitad del siglo XX. Entre ellas, destaca la imagen de una casa desaparecida situada en la parcela 8 , en el inicio de la calle del 
Castillo, frente a la iglesia parroquial de Santiago (Fig. 21). Las fotografías evidencian que la vivienda se adosó a una estructura de tapia calicostrada que sobresalía por encima del tejado llevando una dirección norte-sur, formando un ángulo de $90^{\circ}$ (Figs. 21-23). Situados estos restos en planta, no es arriesgado proponer que corresponden a una de las esquinas del torreón sureste de la fortaleza, al que se le adosó, extramuros, una vivienda (Fig. 18). Este mismo fenómeno se puede observar en el torreón noroccidental, contra el que se construyó por el norte otra casa (parcela $\left.n^{\circ} 15\right)$.

A continuación, haremos un repaso de las parcelas en las que hemos identificado algunos tramos de la muralla. En la mayoría de los casos los restos arqueológicos estaban visibles, mientras que en otros aparecían cubiertos por enlucidos y reutilizados como paredes medianeras.

En dos solares (parcelas 10 y 13), situados extramuros, intentamos localizar la muralla en extensión y para ello retiramos la capa de escombros y vegetación que los cubría.

Parcela 10. Está situada en la placeta de Isso $\mathrm{n}^{\mathrm{o}} 11$ (Fig. 20). Tras una primera limpieza se comprobó que los restos de la muralla eran muy escasos debido a que fue arrasada para ampliar la superficie disponible de la parcela en la que se edificó la casa que allí había. La destrucción de la muralla ha permitido analizar su proceso constructivo que, en un primer momento, consistió en recortar verticalmente la plataforma rocosa sobre la que se erigió la fortaleza y crear un escalón artificial sobre el que se levantó la muralla. En sección se aprecia que esta se insertó en el escalón, quedando la mitad exterior sobre su basamento en la parte más baja y la otra sobre la zona alta del escalón.

En la esquina noroccidental de este solar se ha realizado una limpieza más profunda, exhumando un tramo de muralla que alcanza una altura máxima de $58 \mathrm{~cm}$, sobre una cimentación de $40 \mathrm{~cm}$. Está construida con tapia de calicanto compuesta por tongadas de piedras tomadas con mortero rico en cal. Cada hilada alcanza una altura aproximada de $20 \mathrm{~cm}$. En la base de la muralla se ven seis mechinales con unas dimensiones de 6,5-8 $\mathrm{cm}$ de ancho, 2,5-5 $\mathrm{cm}$ de alto y $31-51 \mathrm{~cm}$ de profundidad (Figs. 24 y 25$)$.

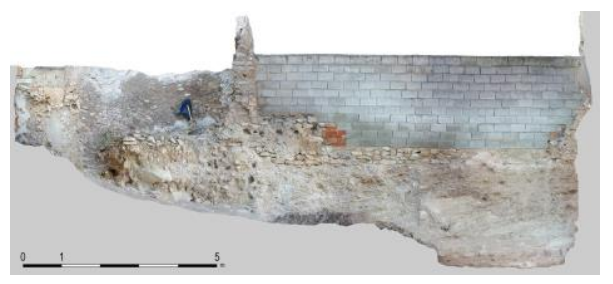

Fig. 24. Isso. Plaza de la Iglesia. Parcela $n^{\circ} 10$. Ortofotografía del tramo de muralla. Bajo el muro de bloques de hormigón se ve el recorte vertical que se hizo en la plataforma rocosa para construir la muralla y los restos de ella organizados en hileras de mampuestos y capas de mortero de cal.

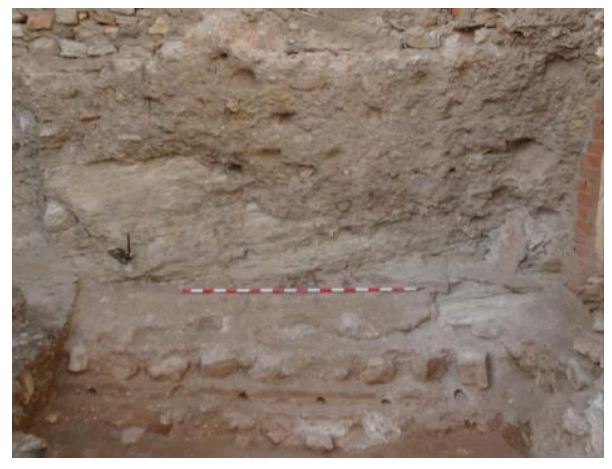

Fig. 25. Isso. Plaza de la Iglesia. Parcela $n^{\circ} 10$. Ángulo noroccidental del solar. Se ve el recorte que se hizo en la plataforma rocosa con el fin de construir la muralla.

Parcela 13. Está situada en el Camino de la Fuente $n^{\circ} 5$ (Fig. 20). En este solar también se ha documentado el mismo proceso de expolio de la muralla que hemos visto en el solar precedente. En este caso, el intento de ganar superficie habitable fue más ambicioso que en el anterior pues se llegó, incluso, a excavar tres oquedades en la plataforma rocosa del cerro sobre el que se construyó la muralla (Figs. 26 y 27).

La primera está situada en la parte oriental y fue excavada bajo la parcela $n^{\circ} 4$. Presenta una superficie de 140 x $130 \mathrm{~cm}$ y una altura máxima de $182 \mathrm{~cm}$. Dispone de un pavimento com- 
puesto por baldosas de barro cocido $(21 \times 21$ $\mathrm{cm}$ ) de color rojo (Fig. 28).

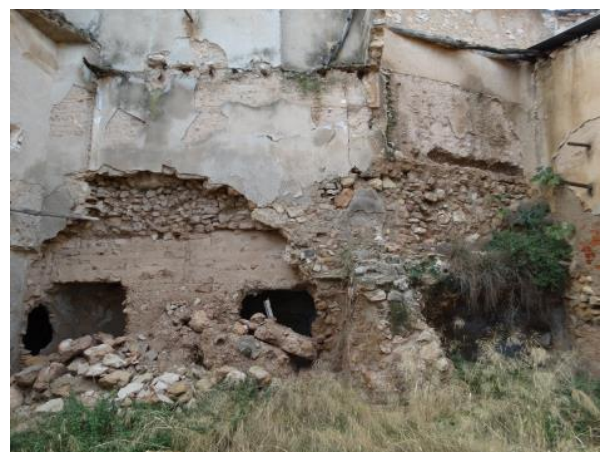

Fig. 26. Isso. Parcela $n^{\circ}$ 13. Calle Camino de la Fuente, $n^{\circ} 5$. Antes de la exploración arqueológica.

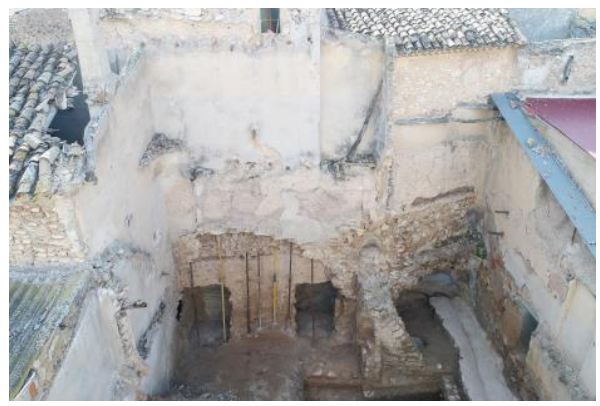

Fig. 27. Isso. Parcela $n^{\circ} 13$. Calle Camino de la Fuente. Al fondo la medianería con las parcelas 3 y 4 .

La segunda se introduce bajo la medianería que separa las parcelas 3 y 4 . Tiene unas dimensiones de $190 \times 250 \mathrm{~cm}$ y una altura de $200 \mathrm{~cm}$, aunque no conserva el pavimento.

La tercera es la más occidental y se introduce debajo de la parcela $n^{\circ} 3$. Es la de mayores dimensiones y está en contacto por el oeste con la parcela 14. Es de planta ovalada y en su interior identificamos cinco tinajas bajo el suelo.

En las secciones ocasionadas por las tres oquedades excavadas en el zócalo inclinado de la muralla se vio cómo este forra el sustrato rocoso del cerro dispuesto oblicuamente (Fig. 28).

El abandono del solar durante muchos años provocó, en fecha imprecisa, el desplome parcial de la medianería, dejando al descubierto restos de la muralla (Fig. 27). La intervención se centró en retirar los escombros y proceder al apuntalamiento de la medianería con el fin de evitar su colapso completo y el derrumbe del edificio inmediato (parcela 4).

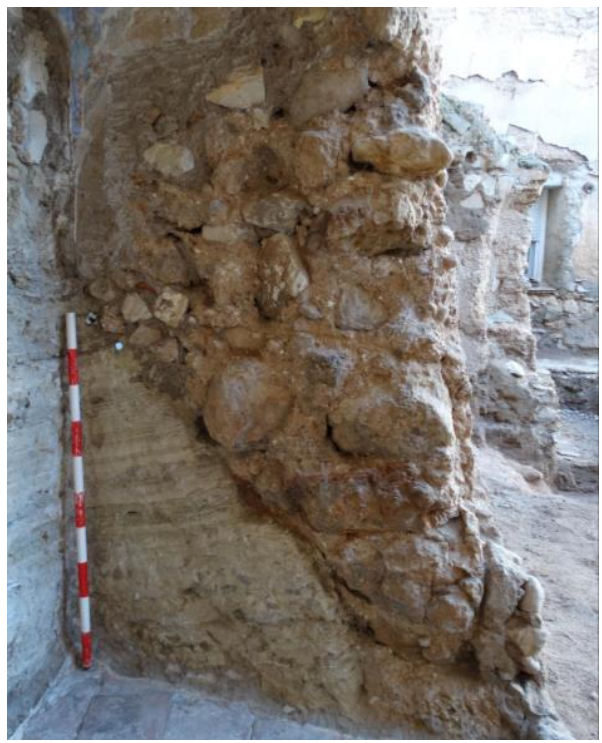

Fig. 28. Isso. Parcela $\mathrm{n}^{\circ} 13$. Calle Camino de la Fuente, $\mathrm{n}^{\circ} 5$. Sección del edículo oriental en el que vemos la muralla y su asiento sobre la base rocosa dispuesta en talud.

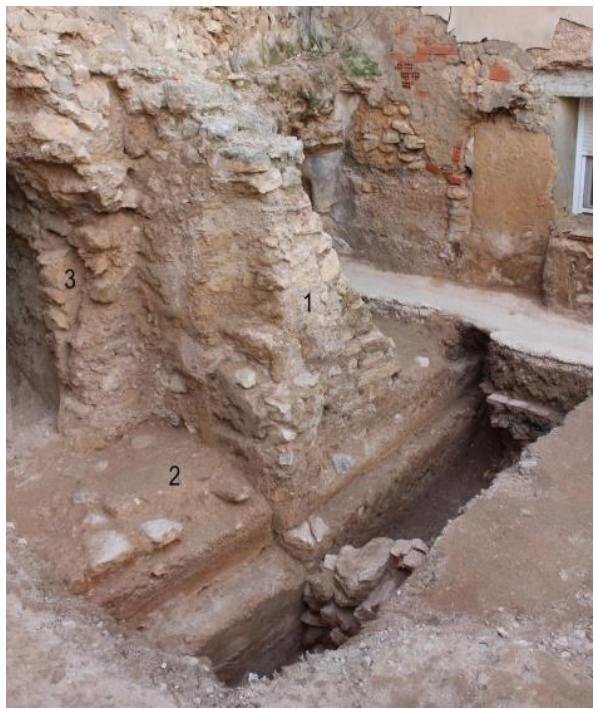

Fig. 29. Isso. Parcela $n^{\circ}$ 13. Calle Camino de la Fuente, $n^{\circ} 5$. En el centro de la foto se aprecian los restos de un torreón (1) y a su derecha se localiza el basamento de un forro (2) que se adosó a la muralla (3) y que fue arrasado por la casa allí construida. 
Allí comprobamos que la muralla tenía, al menos, dos fases. A la más antigua correspondía un lienzo de muro y un torreón de tapiería muy rica en cal y piedra (Figs. 28 y 29). A la fase más moderna pertenece un forro también construido con tapia, de $132 \mathrm{~cm}$ de grosor (incluyendo los $32 \mathrm{~cm}$ que mide la zarpa), adosado a la estructura más antigua y enrasado con el torreón (Fig. 29).

Parcela 4. Esta casa se encuentra en el interior del recinto de la primitiva fortaleza, en su ángulo noreste (Fig. 20). Su patio está delimitado por la antigua cerca. En su frente norte, en contacto con la pared medianera en la que se apoya la casa de la parcela 12 , hubo una crujía que al hundirse ha dejado visibles los restos del torreón de esquina (Fig. 30).

En la foto se aprecia el contacto del torreón con lo que parece ser un lienzo de muralla de tapias con mayor abundancia de tierra. El hecho de que el torreón esté seccionado, permite comprobar que es una obra maciza de mampostería careada, probablemente encofrada, con piedras de mayor tamaño en sus caras. Los restos conservados del torreón pertenecen a su planta baja, lo que permite plantear la hipótesis de una segunda planta con una cámara habitable. La información extraída en esta parcela es complementaria con la que a continuación veremos al analizar los restos arqueológicos existentes en el interior de la vivienda vecina situada en la parcela 12 .

Parcela 12. La casa fue construida extramuros y se adosó al frente septentrional de la muralla, mientras que la vivienda de la parcela 4 hizo lo propio desde el interior del recinto, reutilizando inicialmente la muralla como pared medianera (Fig. 20).

En la cámara de la casa $\mathrm{n}^{\circ} 12$ se comprobó que el muro medianero con la parcela 4 es una obra de tapiería (Fig. 31). A pesar de que estaba cubierto por enlucidos de yeso en algunas zonas, se distinguían sus mechinales y las improntas de los clavos de los tapiales alineadas verticalmente (Fig. 32).

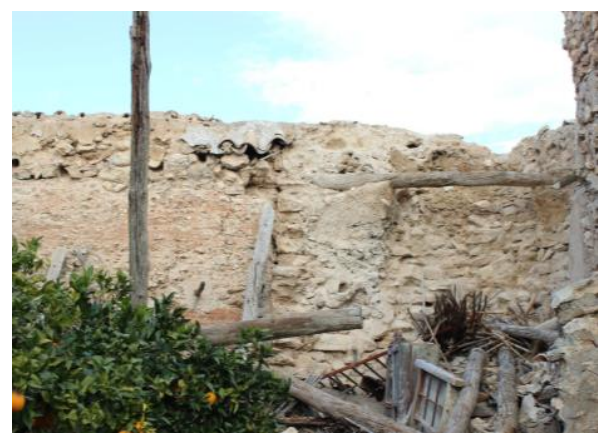

Fig. 30. Isso. Parcela $n^{o} 4$. Frente norte del patio de la casa. El muro es pared medianera con la parcela $n^{\circ}$ 12. La obra de mampostería (derecha) perteneció al torreón de esquina.

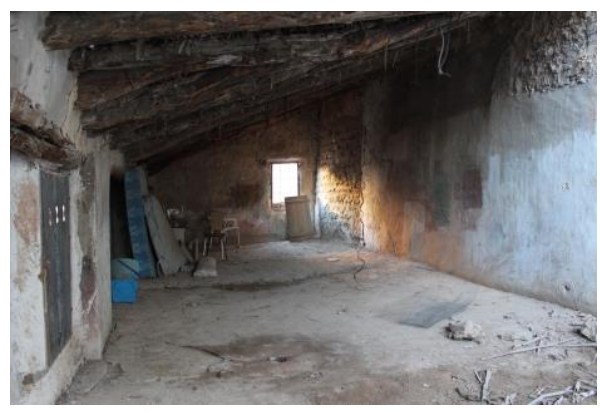

Fig. 31. Isso. Parcela ${ }^{\circ} 12$. Calle camino de la Fuente. Vista de la cámara desde el oeste. A la derecha está el muro medianero entre las parcelas 4 y 12 que parece ser la muralla. Al fondo, a la derecha de la ventana, hay una fábrica de mampostería encofrada que podría pertenecer al torreón de esquina noreste.

En el extremo oriental de este mismo muro identificamos una fábrica de mampostería encofrada en la que se aprecia muy bien la alternancia de las hiladas horizontales de piedra y las capas de mortero de cal (Fig. 33). Aunque no podemos dar cronologías absolutas para esta fábrica, reconocemos que se asemeja a obras anteriores al siglo XII. Esta fábrica de mampostería parece diferente de las otras que hemos visto en el resto de la fortaleza, concretamente a la tapiería de hormigón ciclópeo o a la de tierra calicostrada.

Una hipótesis que podría explicar estas diferencias es que la mampostería encofrada de la parcela $n^{\circ} 12$ perteneciera a una fase antigua de los torreones de esquina que después serían trasdosados con diferentes fábricas de tapiería. 
La obra de mampostería que acabamos de describir es la cara opuesta de los restos del torreón de esquina conservados en el patio de la casa $n^{\circ} 4$ (Fig. 30); en este último vimos una clara discontinuidad de fábricas, entre la mampostería encofrada perteneciente al torreón y la tapia rica en tierra rojiza, que de nuevo vemos en la cara de la muralla conservada en el cámara de la vivienda $n^{\circ} 12$.

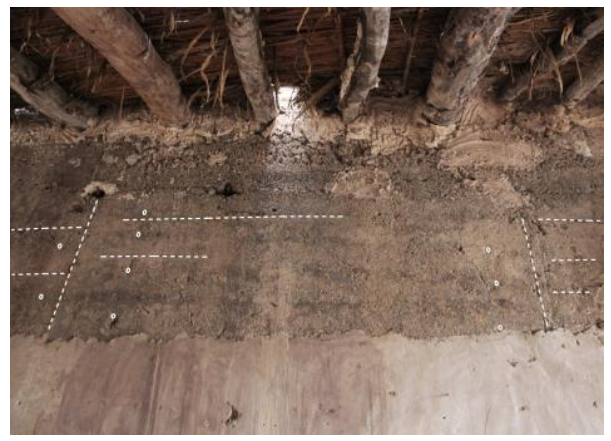

Fig. 32. Isso. Parcela n ${ }^{\circ} 12$. Calle camino de la Fuente. Detalle del muro medianero entre las parcelas $4 \mathrm{y}$ 12, en el que se aprecian los mechinales y las improntas de los clavos y tablas de los tapiales.

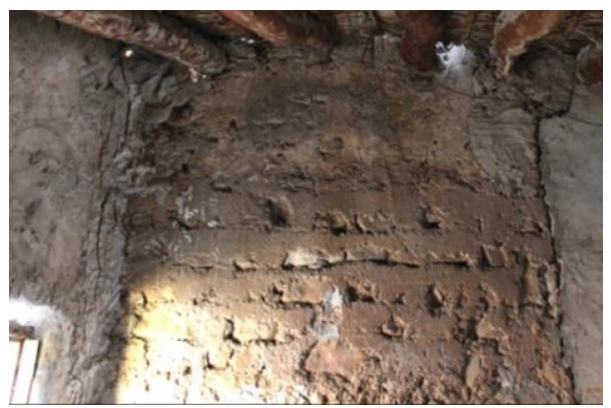

Fig. 33. Isso. Parcela ${ }^{\circ} 12$. Calle camino de la Fuente. Detalle del muro medianero entre las parcelas $4 \mathrm{y}$ 12. Se trata de una obra de mampostería encofrada que pudo pertenecer al torreón de esquina noreste.

Parcela 11. Al hacer el levantamiento de este edificio pudimos comprobar que su medianería occidental, además de ser irregular, era muy gruesa, lo que podría indicar que estamos ante los restos del torreón de esquina nororiental localizado en el patio de la casa $n^{\circ} 4$. Lamentablemente, no vimos su fábrica debido a que el inmueble está en uso y por ello no fue posi- ble picar los enlucidos que la cubren. Además de los restos documentados en su interior, esta antigua vivienda conserva en su exterior los restos de un machón de tapiería, situado en la medianera que separa las parcelas 11 y $12 \mathrm{~b}$ (Fig. 34). En este caso se puede afirmar que la tapia conservada en el exterior nada tiene que ver con la obra de mampostería que conforma el torreón de la parcela 4 (Fig. 30).

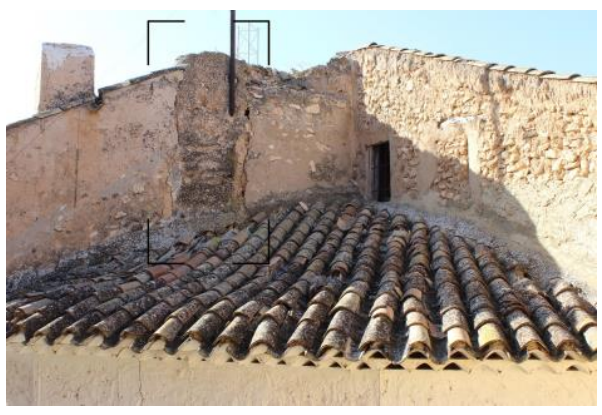

Fig. 34. Isso. Calle camino de la Fuente. Se señala un machón de la muralla conservado entre las parcelas $11 \mathrm{y} 12 \mathrm{~b}$.

Parcela 14. En su frente occidental se ha analizado un muro de hormigón de cal que constituye, actualmente, la base del patio de la casa (Fig. 35). La situación de esta estructura con respecto al lienzo de muralla del frente occidental, y el hecho de que conforme una esquina, permite plantear que se trata de la base maciza de un antiguo torreón de esquina de grandes dimensiones (Fig. 18).

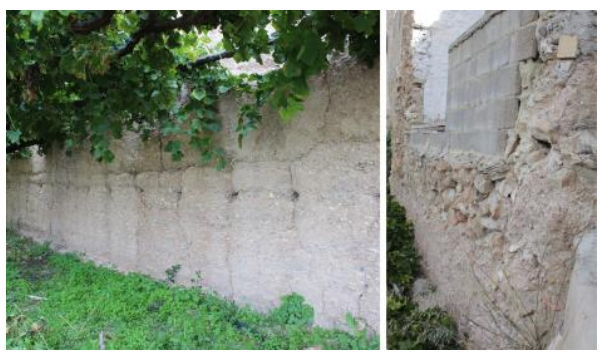

Fig. 35. Isso. Parcela $n^{\circ}$ 14. Muro de tapiería de hormigón de cal situado en el frente occidental de la casa. La parra impidió documentar todo su alzado en una sola foto.

Parcela 1. En el frente occidental de esta parcela, en su tramo más septentrional, en contac- 
to con la $n^{\circ} 2$, hay un cobertizo construido en el huerto anexo, en cuyo interior se puede apreciar un recorte en el sustrato rocoso, dispuesto oblicuamente a lo que sería la línea de muralla (Fig. 36). Actualmente se trabaja con varias hipótesis; una de ellas consiste en que este recorte corresponde a la línea que ocupó en su día el frente norte de un torreón intermedio. De la presencia de estos torreones menores, situados entre los mayores de esquina, tenemos la evidencia arqueológica del ejemplo hallado en la parcela 13 (Figs. 18, 20 y 29). En los otros frentes de la fortaleza también hay indicios de su existencia.

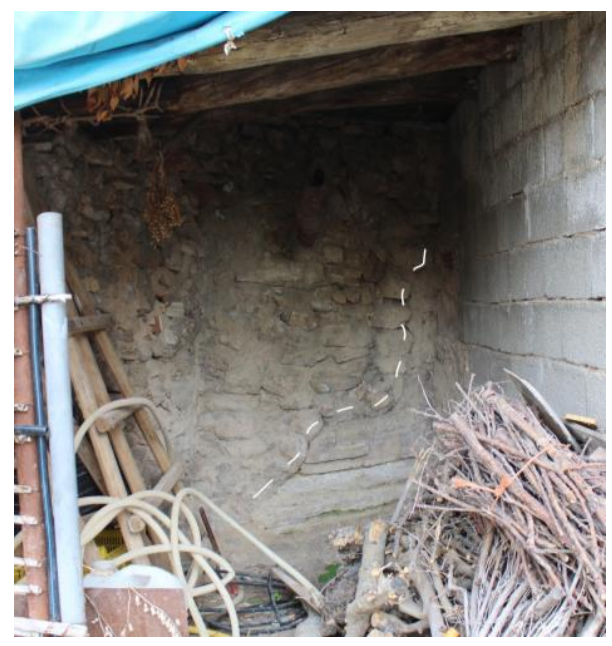

Fig. 36. Isso. Cobertizo en la parcela $\mathrm{n}^{\circ} 1$, donde puede verse el recorte del sustrato rocoso que podría responder a la presencia de un torreón desaparecido.

\section{El castillo. La torre y la puerta del ángu- lo suroeste}

El cerro, la fuente y el camino son los elementos que explican el emplazamiento de la fortaleza. El camino de la Fuente y su continuación por la acequia (Fig. 10) determinan el eje original a cuyo lado oriental surge, en un punto más sólido y elevado que su entorno, la fortaleza. Seguridad, comunicación y abastecimiento son los tres factores que explican la presencia de una fortaleza en este preciso lugar, factores a los que podríamos añadir un cuarto: prestigio.
Como hemos comentado en el capítulo anterior, el castillo de Isso desapareció, arruinado o demolido, prácticamente en su totalidad, excepto el complejo constructivo formado por una gran torre, la puerta anexa y los dos lienzos de muralla que salen de él (Fig. 51). Todos estos restos están situados en el ángulo suroccidental del barrio que amortizó la fortaleza y se han conservado formando parte de la casa que ocupa la parcela $\mathrm{n}^{0} 1$, excepto el tramo de muralla que hay entre las parcelas $n^{0} 6$ y 7 (Fig. 20). La evidencia de sus estructuras contrasta con la situación de olvido en la que han llegado hasta nosotros. A veces, como en este caso, el topónimo se ha grabado más en la memoria que el propio edificio. Sorprendentemente, el POM de Hellín no recoge el "Castillo de Isso" en su catálogo a pesar de estar declarado bien de interés cultural en virtud de la disposición adicional segunda de la Ley del Patrimonio Histórico Español. Sin embargo, sí aparece en el "Inventario de yacimientos de la carta arqueológica provincial" y sólo en este sentido se recoge en el Plan.

El castillo dibuja una planta cuadrangular con grandes torres en las esquinas, decía el canónigo Lozano en el siglo XVIII. En una de ellas, la suroeste, se encuentran los elementos que dieron principio a nuestro estudio. Se trata de dos torres, cuya proximidad señala su función de puerta (Fig. 37).

Los accesos a una fortaleza necesitan identificarse desde lejos para cumplir su función, a menos que se trate de una puerta secundaria o que tenga cierto carácter secreto. Se manifiestan como un hueco en un muro, pero también como un par de torres muy cercanas. Una posición de esquina marca un punto de privilegio, mientras que cuatro señalan un recinto.

La topografía de la zona indica que el terreno desciende hacia el sur y hacia el este. Sin embargo, el desarrollo de la muralla oeste asciende hacia el sur, lo cual podría ser un indicio de la voluntad de preponderancia de la gran torre suroeste, además de la necesidad de ir aproximándose al nivel del adarve sur. 


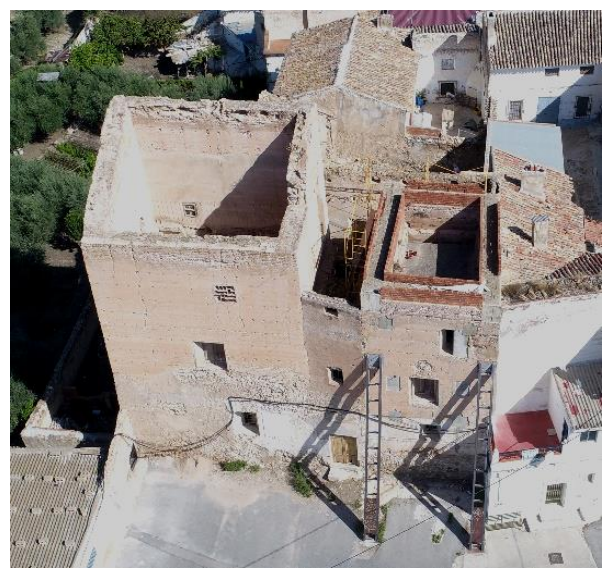

Fig. 37. Isso. Vista aérea de las dos torres.

Todo está construido mediante tapias de argamasa y mampuestos en la base y de tierra con costra en altura. El aspecto de la tapiería es bastante uniforme, al menos en los sectores donde sus paramentos, que son sensiblemente verticales, se conservan en buen estado. Parece que la sección de la tapia varía en su composición, aumentando la presencia de tierra conforme se aproxima a la costra de la cara interior.

En la torre mayor podemos contar hasta $25 \mathrm{hi}-$ ladas de tapia, cada una con 18 mechinales en su lado mayor y 14 en su lado menor, dispuestos de tal manera que existe correspondencia vertical entre los de hiladas sucesivas; lo mismo ocurre en la torre menor. Esa correspondencia y la ausencia de juntas verticales supone un indicio de que cada hilada se encofró y confeccionó de una forma continua, montando varios tapiales al mismo tiempo. Este panorama nos recuerda lo visto en otras torres del entorno, como la de Taibilla (Nerpio, Albacete). La altura media de las tapias es de unos $83 \mathrm{~cm}$. No se aprecian juntas de trabajo, ni huellas de barzones, salvo en una tapia situada en la cara interior de la primera hilada del lienzo occidental visto desde el patio (Fig. 38); por el contrario, sí se observan líneas de clavos en algunos puntos de ambas torres (Fig. 39).

Las agujas no traspasan toda la anchura de la tapia como corresponde, normalmente, a la construcción de muros de gran espesor. Las agujas se disponen dentro de un cajeado de la tapia inferior y son de un solo uso; una vez terminada la tapia, se cortan y la mitad interior permanece dentro de la masa del muro.

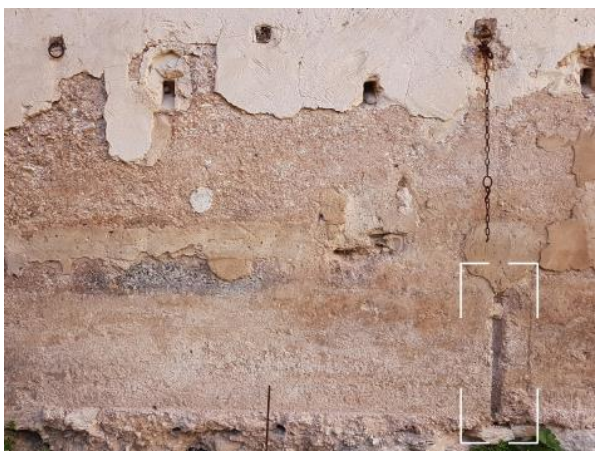

Fig. 38. Isso. Lienzo occidental visto desde el patio. Detalle de la impronta del barzón.

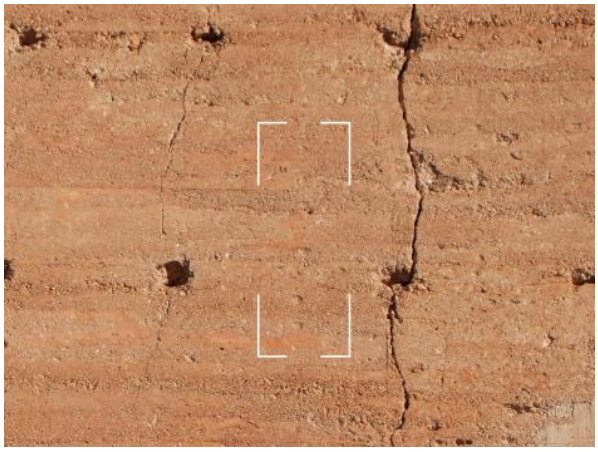

Fig. 39. Isso. Fachada sur de la torre suroeste. Detalle de la impronta de los clavos del tapial dispuestos verticalmente.

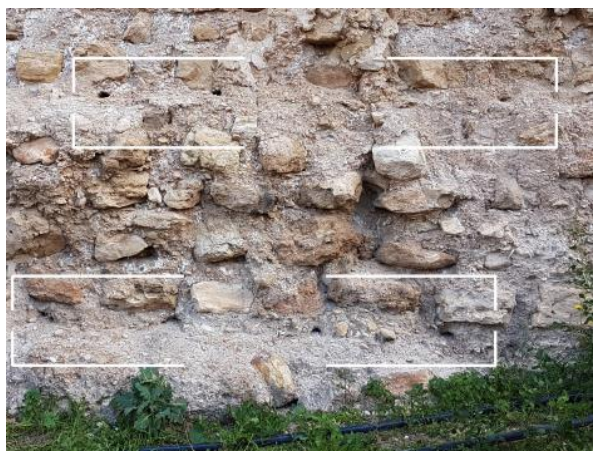

Fig. 40. Isso. Base de la esquina noroeste de la torre suroeste. Se puede apreciar los mechinales de las agujas situadas sobre dos zarpas. 
Se distinguen dos zarpas en el muro oeste de la torre mayor (Fig. 40) y, en el caso de que existieran en otros muros, no se ven debido a que los muros arrancan de cotas más altas o están semienterrados en la actualidad.

Las murallas. Las murallas se interrumpen en las torres, por lo cual los recorridos debían continuar por su interior. Se conservan sendos tramos, uno adosado al muro norte de la gran torre de esquina, otro que se adosa al muro oriental de la torre más pequeña. Esos dos tramos no son perpendiculares; se aprecia ortogonalidad entre la muralla oeste y el conjunto de las torres, pero el segundo tramo no es perpendicular a la torre pequeña. El primero presenta desarrollo sur-norte coincidiendo con las direcciones principales del conjunto, incluso coherente con ese sistema de dimensiones que entrevemos (Fig. 41); el segundo presenta un desarrollo suroeste-noreste y su dirección no guarda paralelismo con ninguna de las torres que estamos tratando, sin embargo, guarda una mayor ortogonalidad con el muro que se conserva al noroeste de la manzana (Fig. 20). El lienzo oeste conserva restos del adarve, pretil hacia el exterior y unos escalones descendentes en su extremo norte (Fig. 41).

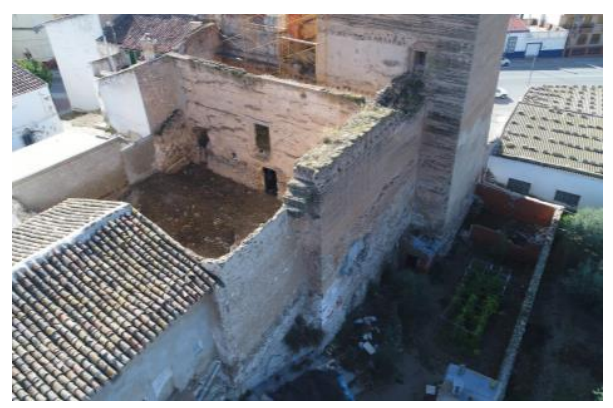

Fig. 41. Isso. Parcela $n^{\circ} 1$. Vista aérea del lienzo oeste. Detalle de la escalera que comunicaba el adarve del nuevo lienzo con el preexistente.

Sobre el lienzo sur podemos suponer que se conserva casi hasta el nivel del adarve, sin restos de pretil. Ambos adarves terminan, al contactar con las torres, en sus correspondientes huecos de paso: el de la torre grande se conserva íntegramente, aunque reformado para usos posteriores (Fig. 41); el de la torre peque- ña se adivina en los restos del muro oriental de esta (Fig. 49). El nivel de los dos adarves no es coincidente, el oriental es más alto.

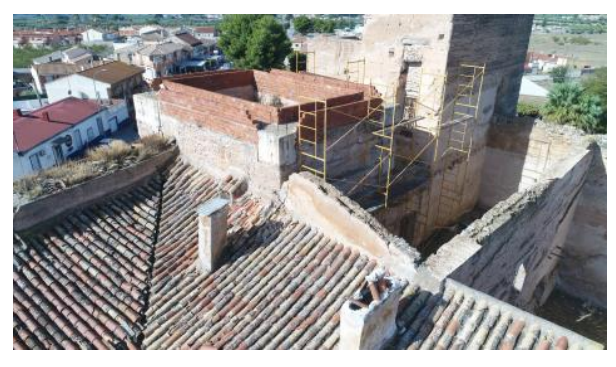

Fig. 42. Isso. Parcela $n^{\circ} 1$. Vista aérea de las torres desde el noreste. En primer plano, detalle del encuentro del lienzo sur con la torre pequeña, donde aparece un hueco tapiado. A la derecha se aprecia el encuentro del lienzo oeste con la gran torre del ángulo suroeste.

Las torres. El conjunto presenta una gran torre en el ángulo suroeste, que conserva casi la integridad de sus muros perimetrales, y una más pequeña al este de aquella, separadas por menos de tres metros (Fig. 37). Aunque sorprende que sus fachadas meridionales no se hallen bien alineadas, ambas se planificaron conjuntamente; prueba de ello es la correspondencia casi perfecta en sus hiladas de tapia; también su replanteo parece que fue una operación única (Figs. 43 y 44 ).

Considerando las dos torres como un conjunto, el muro oriental de la mayor materializa el eje de la planta. A ambos lados de ese muro, que adquiere un carácter central, se plantean sendos cuadrados (aproximados), incluso las diferentes particiones parecen responder a terceras partes (Fig. 45). Podemos imaginar que el replanteo se llevó a cabo en la superficie natural de la roca y que esta debía presentar desniveles; todo parece indicar - pese a que los niveles actuales de calles y calzadas oculten el firme de partida - que el punto más bajo se encuentra en la esquina suroeste; de esa manera, aunque en la base se dibujaran las alineaciones con mayor rigor geométrico, podrían haberse ido desfigurando en la elevación a causa de sucesivos retranqueos. 


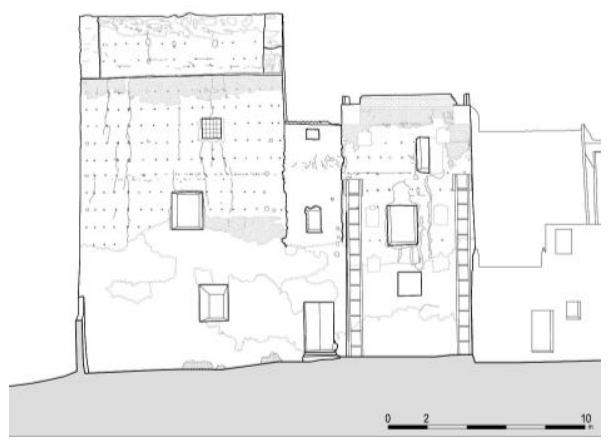

Fig. 43. Isso. Alzado sur. Levantamiento del estado actual de las dos torres.

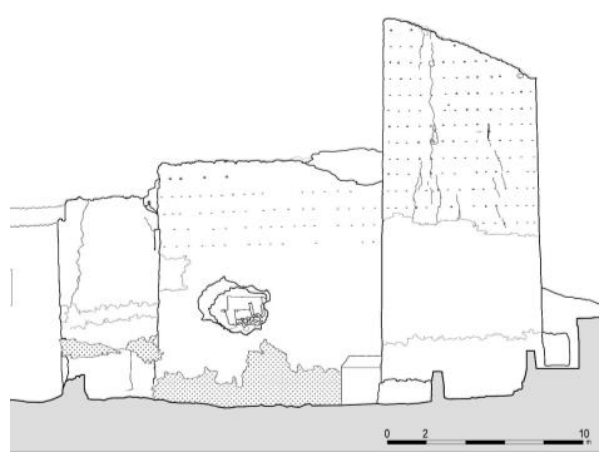

Fig. 44. Isso. Alzado oeste Levantamiento del estado actual de la torre y del lienzo de la muralla occidental.

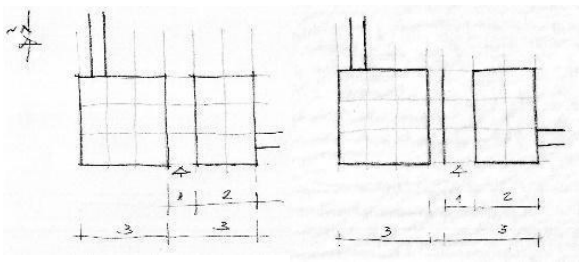

Fig. 45. Isso. Torres de la esquina suroeste. Esquema de una posible ordenación en su concepción.

Esta ordenación teórica podemos verla en algunos detalles:

- En la disposición de las vigas de la torre mayor, donde se conserva en planta baja la viga más occidental y el mechinal de la siguiente; ambas dividen la planta en los tres espacios que indicamos. En la siguiente planta se pue- den observar los mechinales de las vigas (Fig. 46).

- Al límite del primer tercio corresponde también la ubicación del lienzo de muralla oeste.

- La ubicación del lienzo que se conserva adosado al muro este de la torre menor, también se corresponde, aproximadamente, con uno de los tercios de esta.

Los muros de la torre mayor son más gruesos, sin embargo, el espesor del muro norte lo comparte también con la torre menor.

La torre de esquina conserva una altura de 25 tapias, altura que coincide con la de otras torres de las que nos han llegado referencias documentales; mientras su muro norte se halla, prácticamente, con toda su altura, los otros tres fueron rebajados para construir un tejado, a un agua, con pendiente hacia el sur. De la torre pequeña no sabemos su altura total, debido a que fue muy transformada en obras realizadas en los años 80 del pasado siglo; en la actualidad tiene seis tapias menos que el muro norte de la torre grande (Figs. 43 y 44 ) y su última hilada está rehecha prácticamente en su totalidad.

Se conservan algunas saeteras cegadas en el muro oeste de la torre mayor (Fig. 47); las ventanas incluidas en posteriores reformas debieron destruir algunas saeteras en otros muros, aunque, posiblemente, se hayan conservado algunas jambas.

Las torres perdieron sus forjados originales. La suroeste está totalmente vaciada. En la oriental se construyeron, en los años 80 , tres pisos, que se hallan inacabados. Ninguna de las torres tiene, actualmente, cubierta.

La situación de los forjados originales dejó una huella evidente: retranqueos interiores en los muros; estos escalones son útiles para dos cosas: por una parte, van disminuyendo la sección del muro con lo que supone de ahorro de material y de carga, por otra, sirven de apoyo a la estructura secundaria del forjado. Dichos retranqueos no se disponen de la misma manera en ambas torres. 


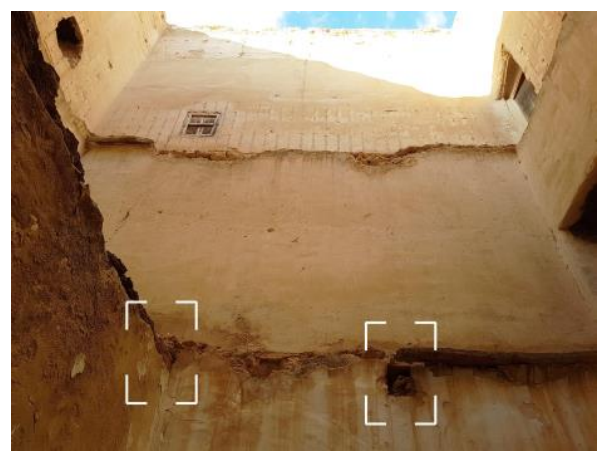

Fig. 46. Isso. Interior de la gran torre (1a). Vista del muro norte: restos de las vigas correspondientes al primer forjado. En el piso superior se pueden apreciar los mechinales de las vigas homólogas.

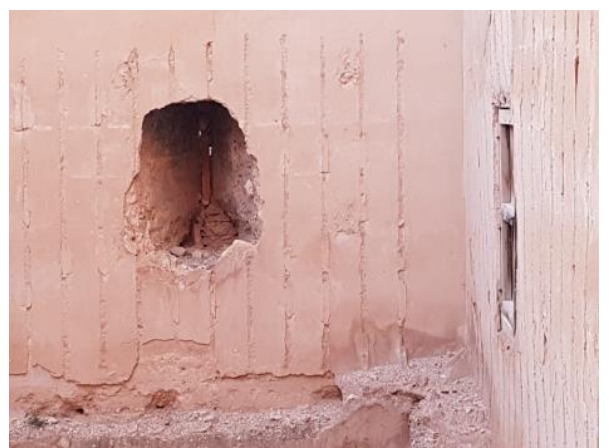

Fig. 47. Isso. Interior de la gran torre de esquina. A la izquierda se aprecia una saetera situada en el segundo piso (tercera planta). A la derecha estaba la puerta que comunica con el adarve oeste, convertida hoy en ventana.

En la torre grande, el escalón se construye en todo su perímetro interno; las vigas, como estructura primaria, tienen, lógicamente, la menor luz posible, es decir, la norte-sur; no se apoyan en el escalón sino que se enrasan con él mediante un cajeado; mientras que las vigas son escuadradas, las viguetas que han llegado hasta nosotros, como elemento conservado o como impronta, son rollizos que se apoyan en los escalones situados al este y al oeste y en las jácenas (Fig. 46).

Además del suelo de la planta baja, podemos ver la huella de dos pisos intermedios. Es posible que existiera un tercer piso que conserve sus improntas bajo los revestimientos que hoy existen. Cada una de las plantas presenta un hueco en su esquina noreste: el de planta baja lo interpretamos como producto de las reformas llevadas a cabo para convertir las torres en vivienda; el correspondiente al primer piso pudo existir desde el principio o ser añadido después; en el segundo piso sí debió de existir desde su origen (con sucesivas variaciones) para posibilitar la comunicación entre los adarves.

En la torre pequeña no hay cajeados para alojar jácenas. Existen dos niveles de escalonamiento interior de los muros: en el inferior solo hay escalón en las paredes norte y sur que, en este caso, delimitan la longitud mayor y, por tanto, la más desfavorable; en el superior el escalón aparece en las cuatro paredes (Fig.48). Después, los muros no conservan más altura. Así, existen forjados homólogos en las dos torres, aunque sus niveles no coinciden: son más altos los correspondientes a la torre pequeña, apreciándose mayor diferencia en los forjados superiores.

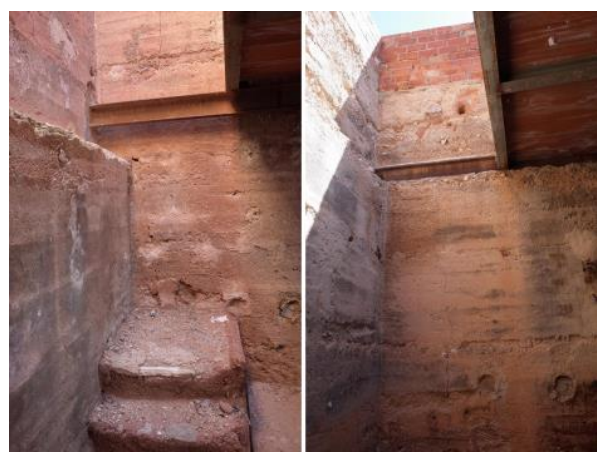

Fig. 48. Isso. Interior de la torre menor. En la foto de la izquierda se ve que la solución de retranquear los muros sólo se produce en el septentrional ( $1^{\mathrm{er}}$ nivel), mientras que en la foto de la derecha se aprecia que el escalonamiento se extiende también a la pared oriental ( $2^{\text {ndo }}$ nivel).

El escalonamiento exclusivo en los muros norte y sur de la torre pequeña, a nivel de primer piso, sugieren, al menos, dos posibles razones: la existencia de una escalera en dirección surnorte, incompatible o, al menos, inadecuada con un forjado en dirección este-oeste; o bien la existencia de una estructura intermedia en dirección este-oeste que, por una parte, disminuyera la luz del forjado dispuesto en direc- 
ción norte-sur y, por otra, creara un espacio diferenciado para la guardia. Actualmente existe una escalera en la que predomina su tramo adosado al muro norte de la torre (Fig. 48), incoherente con el forjado que debió apoyar en ese mismo muro. También podemos observar un poyo que se adosa al muro oeste (Fig. 50), coincidente con la ubicación del posible muro diafragmático.

\section{Escaleras, espacio intermedio y comunica-}

ción. ¿Cómo era la comunicación entre las diferentes plantas dentro de cada una de las torres? Hoy día son escasas las huellas y la mayoría de los vestigios se deben a reformas posteriores. En la torre mayor no hay huellas apreciables, salvo unas señales en la cara interior del muro oeste, a nivel de un hipotético tercer piso. En la torre menor existen, en planta baja, algunos peldaños incluidos en el ancho del muro oeste y un gran tramo de escalera adosado al muro norte (Fig. 48). Todo ello parece incompatible con la función de puerta y con la disposición de un forjado apoyado en el muro norte; es decir, esas estructuras se deben a reformas posteriores, como quedan de manifiesto en algunas huellas de los pisos superiores.

Sin embargo, los edificios necesitan comunicación vertical. Se supone que existieron escaleras que relacionaran todos los pisos, al menos a partir del primero. Estas escaleras pudieron estar constituidas por estructuras simplemente adosadas o apoyadas, incluso, en algunos casos, ser móviles por motivos de seguridad. Todo apunta, aunque no podamos demostrarlo todavía, a que el espacio intermedio debió funcionar, entre otras misiones defensivas, como núcleo de comunicaciones con acceso directo desde el norte. A las dos torres se podría acceder tanto desde los adarves como desde el espacio intermedio.

En las dos torres, como hemos dicho, tenemos la evidencia de tres niveles aunque, muy probablemente, fueran cuatro. En la torre grande, la altura conservada es suficiente para acoger un tercer piso (cuarta planta); en la pequeña, el alzado de sus muros es menor, pero pudo tener una altura similar. Necesariamente, alguno de los niveles debió de estar en comunicación con los adarves; ese nivel se corresponde con el segundo piso -tercer nivel- en ambas torres: en la oeste hay una tronera que parece corresponder con la puerta de entrada desde el adarve occidental; en la este, se dibuja un hueco tapiado en contacto con la muralla oriental (Fig. 49). La diferencia de cota entre los adarves es de, al menos, una tapia, quedando por interpretar cómo y dónde se salvaba ese desnivel (Fig. 43).

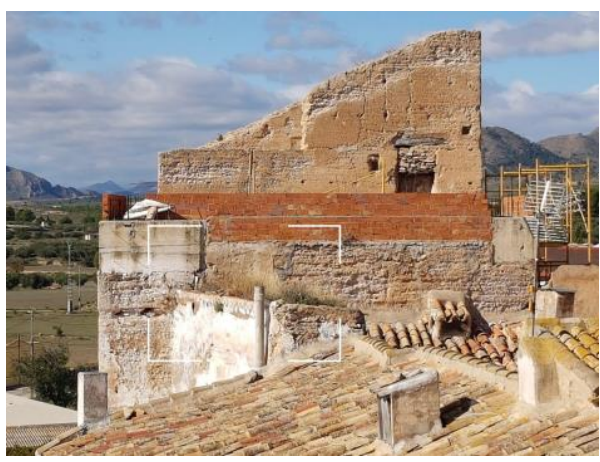

Fig. 49. Isso. Vista de las torres desde el este. En primer plano, la torre menor, en la que se aprecia un vano tapiado que comunicaba el adarve occidental con el interior de la torre.

Debido a la estrechez del espacio intermedio, parece lógico que los escalones necesarios para salvar el desnivel entre adarves deberían estar en el interior del segundo piso de las torres (de una o de las dos). La existencia de tres dinteles superpuestos en el muro este de la torre grande (Figs. 42 y 49), parece indicar que los escalones se hallarían en el interior de esta última. El hueco inferior supone, claramente, el traslado o alargamiento de una abertura bajo un hueco existente; de no ser así, no podríamos explicar que su dintel ocupe sólo una pequeña parte de la profundidad del hueco. Si los escalones interiores tenían que salvar la altura de, al menos, una tapia como hemos dicho, implicaría que el hueco de paso tendría su dintel a una altura aproximada de 4 tapias por encima del nivel de paso actual, el correspondiente al segundo piso de la torre grande.

No sabemos con exactitud cómo estuvo formalizado el espacio entre las torres en origen, sin 
embargo, la solución que allí se adoptó fue crucial desde un punto de vista defensivo. La única realidad comprobada, por ahora, es la presencia del muro norte como nexo entre las dos torres, pero habrá que seguir investigando sobre cómo se organizó este espacio. A continuación, expondremos tres opciones:

a) La existencia de un adarve, como coronación del muro norte, comunicado con las dos torres. En este caso, para posibilitar con eficacia tanto la circulación como el hostigamiento vertical, se debía contar con una anchura superior a la que vemos en los adarves oeste y sur, y para ello era necesaria la presencia de un cadahalso.

b) Una solución complementaria de la anterior sería aquélla en la que este adarve central se encontrara dentro de un espacio cerrado, es decir, con otro muro situado al sur que, incluyendo una primera puerta, delimitara un espacio descubierto, pero totalmente controlado para su defensa. En esta solución, el adarve correspondiente al muro norte representaría una segunda línea de defensa.

c) La tercera opción consistiría en un espacio entre torres totalmente construido y cubierto: cerrado por el sur con un muro, retranqueado con respecto a las esquinas de las torres, que incluiría la primera puerta. Este cuerpo central contaría, al menos, con un piso intermedio; el cual podría estar comunicado directamente con la planta baja de la torre pequeña, aunque esta relación parece una debilidad desde el punto de vista defensivo. La terraza de remate podría funcionar como un ensanchamiento entre adarves e, incluso, estar proyectada, en voladizo, hacia el exterior.

La existencia de buhederas, buzones y cadahalsos la podemos suponer pero no descubrir en los restos conservados.

Fuera como fuera el espacio entre las torres, parece que tendría una cierta independencia constructiva (no de concepción) entre la gran torre oeste y el resto. Aunque se diera una continuidad funcional, el muro este de la torre grande se ve construido sin traba con el resto, tal como muestran sus mechinales y paramen- tos conservados. Esta independencia constructiva queda subrayada por una fisura casi vertical que recorre el encuentro entre la esquina noreste de la torre y el tramo de muralla que la une a la torre menor. El recurso de adosar, en vez de trabar, es utilizado habitualmente para evitar que la posible ruina de un elemento arrastre al otro.

La hipótesis de la puerta. La planta de la torre pequeña sugiere una perfecta entrada en recodo (Fig. 51). Pero dicho paso carecería de suficiente seguridad a no ser por el flanqueo que añade la gran torre de esquina.

Aceptada la función de puerta para el conjunto de las dos torres, la siguiente cuestión radicaría en discutir cómo se accedía y con qué recursos defensivos se contaba. ¿Dónde se hallaría el primer hueco de entrada? En principio, no lo podemos saber sin excavaciones arqueológicas que ayuden a descubrir huellas de su construcción. El callejón que se forma entre las dos torres podría contar con un diafragma frontal o no, en caso de existir en ese punto la primera puerta.

Una vez en esa especie de desfiladero, fácil de defender desde ambas torres, nos podemos preguntar dónde se hallaría el siguiente hueco. Un hueco frontal en la muralla norte no es completamente descartable -hoy existe unopero, aunque perfectamente flanqueado y con posibilidad de hostigamiento vertical, supondría desaprovechar el recurso de un primer recodo. Parece que la entrada directa a una gran estancia en planta baja de la torre principal hoy existe un vano- tiene poco sentido, pues conllevaría el acceso directo a un enclave muy comprometido y vulnerable al fuego.

El muro occidental de la torre pequeña, a la derecha del ingreso, representa la tercera posibilidad. Paradójicamente, es el único paramento que, en la actualidad, no presenta ningún hueco pero, desde el interior de la torre, podemos apreciar cómo la mitad norte de ese muro está prácticamente hueca (Fig. 50). Si a esa circunstancia añadimos que la puerta que comunica la planta baja de esa torre con el interior de la fortaleza se halla en la esquina noreste, puede quedar dibujada una entrada perfecta en 
recodo: el primer paso se hace hacia la derecha, sin protección ante la guardia situada en la mitad sur de la sala; el segundo hacia la izquierda dando la espalda al cuerpo de guardia; tras ese segundo giro, por el momento, no podemos saber si hubo nuevos obstáculos y si el espacio estaría techado o se entraría a un patio descubierto, totalmente controlado desde los adarves (Fig. 51). Como hipótesis, ese patio podría no tener toda la anchura que hoy encontramos sino, más bien, ser un espacio confinado por otras construcciones.

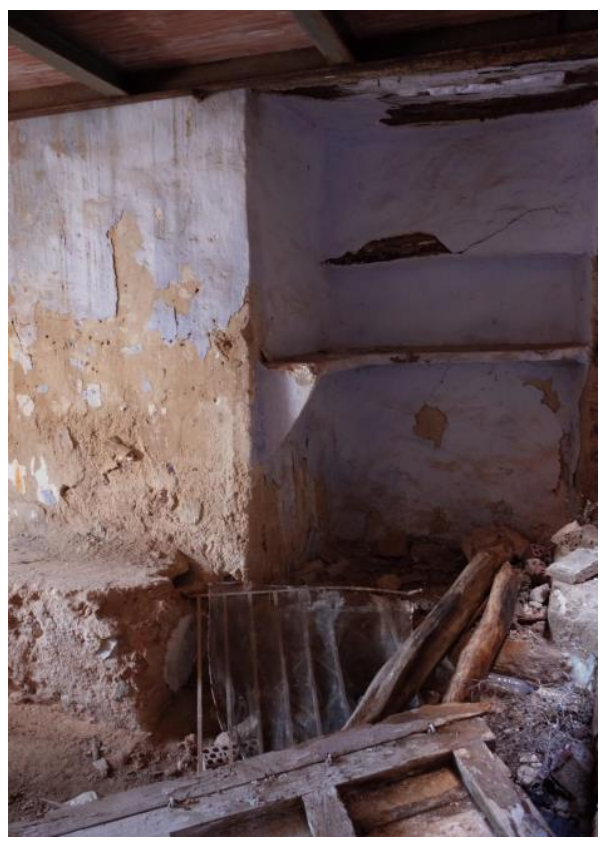

Fig. 50. Isso. Interior de la torre menor. Planta baja Muro oeste. Detalle de la alacena generada al tapiar la puerta medieval de acceso a la torre. La altura a la que se emplaza el forjado metálico actual no se corresponde con el medieval.

El complejo de puerta que acabamos de describir parece deberse a una reforma bajomedieval castellana, la última gran obra llevada a cabo en la fortaleza medieval. Con algunas modificaciones, fue el germen de la actual parcela 1. A dicha reforma se deben las torres y el lienzo oeste, no así, posiblemente, el lienzo oriental. Hay dos razones, al menos, que refuerzan lo que acabamos de exponer: el lienzo occidental y ambas torres presentan una conti- nuidad casi perfecta en sus hiladas de tapia, además, los tres elementos se organizan con las mismas direcciones. Por el contrario, el lienzo oriental presenta otra dirección perpendicular a un tramo más antiguo existente en el extremo noroeste de la manzana- y no se ha podido constatar que guarde continuidad en las hiladas de tapia, debido a que no ha sido posible analizarlo por estar enlucido. La reforma castellana, no sólo debió suponer el refuerzo o reparación de estructuras anteriores, sino que sirvió para delimitar un sub-recinto con límites precisos y funcionamiento independiente.

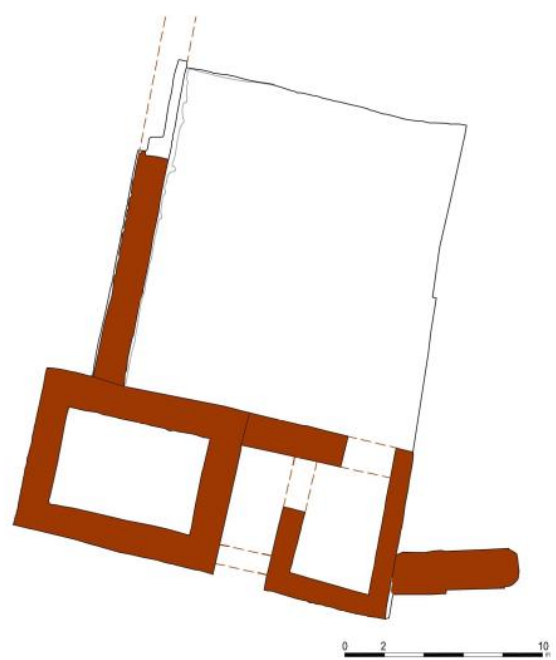

Fig. 51. Isso. Parcela $n^{\circ} 1$. Hipótesis del estado inicial del complejo arquitectónico de la puerta de acceso a la fortaleza medieval.

El escaso desarrollo de los lienzos de muralla anexos a los torreones creemos se debe a que formaron parte de la reforma medieval cristiana que sustituyó, en este sector, a la fortificación primigenia, entestando la nueva obra a dos torreones, preexistentes e intermedios, que posteriormente fueron destruidos con el resto de la fortaleza antigua. Sin embargo, como hemos apuntado, la naturaleza del tramo de muralla sur, al este de la torre pequeña, puede ser diferente.

El hecho de que este sector se haya mantenido hasta nuestros días, apoya la interpretación de que se trata de la última gran reforma, adecua- 
ción y mejora de la fortaleza, que perduró convertido en casa ligada con la aristocracia local.

\section{Evolución constructiva de la fortaleza}

A partir de los datos recabados mediante la documentación escrita y, sobre todo, arqueológica, podemos proponer tres grandes fases para explicar la evolución constructiva del espacio en el que se construyó la muralla de la fortaleza. Este proceso debe entenderse como una sucesión de trasdosados cuyo desarrollo empezó con el recorte y forrado de la base rocosa, pasando por la sucesiva construcción de murallas, las cuales reutilizaron o demolieron la muralla sobre la que, en un principio, se fueron adosando.

Primera fase. Hemos comprobado que para su edificación se escogió un pequeño cerro situado en el punto en el que confluyen el camino de Hellín - Elche de la Sierra y la acequia proveniente de la Fuente de Isso. Hecho el replanteo de la fortaleza, se procedió a recortar el sustrato geológico generando así un escalón que proporcionaba mayor altura a los futuros alzados de las murallas y, por tanto, mejores condiciones de defensa, así como una imagen más intimidante. Ante la naturaleza de la roca calcarenita de este promontorio y su posible vulnerabilidad por resultar fácilmente excavable y deleznable, se acometió una operación constructiva de forrado de los recortes realizados en el sustrato rocoso. A continuación, se emprendió la construcción de la muralla, que se complementó con la incorporación de torres o bastiones que aumentaban la defensa al agrandar el espesor y proporcionar puntos de flanqueo (Fig. 28 y 36 ).

Segunda fase. La necesidad posterior de mejorar las cercas, repararlas, o agrandar el perímetro, generó un segundo trasdosado. De esta forma los muros se hicieron más gruesos y, por tanto, con mayor estabilidad, reforzando las partes que más se verían afectadas por la humedad de capilaridad y de drenaje del promontorio rocoso, haciéndose a su vez más resistentes ante posibles impactos. El ensanchamiento de los muros habría provocado el relleno de los espacios entre torres, de manera que el funcio- namiento táctico del sistema debería conllevar, no sólo el aumento de espesor en los lienzos, sino la disposición de nuevas torres de flanqueo que podían disponerse en los mismos puntos o en otros nuevos. Sin embargo, la función de las torres emplazadas originalmente en el centro de los lienzos podría haber desempeñado una función meramente estructural como contrafuerte prescindiendo de la misión de flanqueo, hecho que podría explicar el por qué en el único caso donde han podido ser excavados sus restos -solar de la parcela 13-, la torre no se recreció al mismo tiempo que lo hacía la muralla (Fig. 29). Este crecimiento a base de trasdosar las preexistencias tiene una ventaja adicional: la posición relativa de los diferentes puntos interiores sigue siendo la misma, de manera que puede cambiar la eficacia y prestaciones de la defensa, pero no necesariamente el orden interno. Una primera observación que se puede hacer al contemplar la planta de la fortaleza es el excesivo tamaño de sus torres de esquina, lo que permitiría plantear la hipótesis de que fueron recrecidas con un gran forro de tapia, mientras que las intermedias fueron embebidas por el mencionado forro. Hay datos que evidencian que las primitivas torres de esquina -torre noreste-, presentaban una fábrica de mampostería encofrada que posteriormente fue forrada con tapias de diferentes características -torre noroccidental- (Fig. 18).

Tercera fase. Cuando la fortaleza perdió su sentido como defensa, entró en un estado de abandono y deterioro. Fue entonces, cuando sus murallas en unos casos sirvieron de cantera $\mathrm{y}$ en otros fueron reutilizadas, como estructuras sobredimensionadas, en las nuevas construcciones que terminaron conformando el barrio de la fortaleza (Fig. 52).

En este momento se repiten operaciones de trasdosado, pero ya no de muros sino de espacios. Aparece una nueva necesidad de superficie doméstica junto a una vocación de aprovechamiento y reutilización que cambian la lógica de las intervenciones: sobra espesor de muro y se ambiciona espacio, lo que antes era exterior que había que proteger ahora se convierte en elemento interior, privado, y se manipula casi sin limitación. 


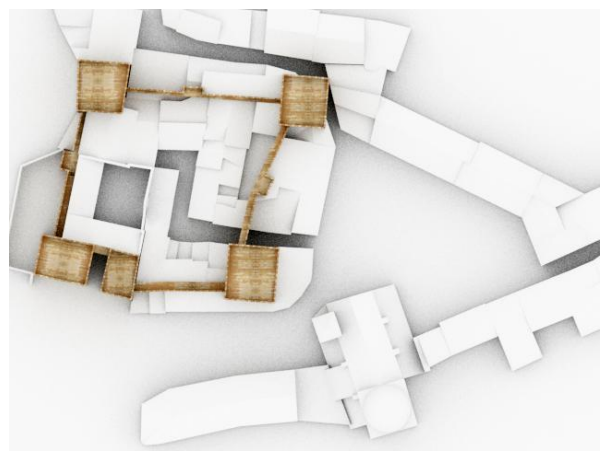

Fig. 52. Isso. Estado de su caserío antes de la apertura de la nueva carretera, trazada en la segunda mitad del siglo XIX.

La muralla subsiste en la medida que sigue siendo útil y, en la mayoría de los casos, fue como pared medianera (Figs. 26 y 31). En los tramos en los que no es demolida, se la reduce al mínimo indispensable para asegurar una capacidad de carga adaptada a las nuevas necesidades. Cuando no se le adosan casas por el exterior, sus alzados son eliminados, como sucede en su flanco occidental, concretamente en los frentes de las casas que allí se abren (parcelas 2 y 14) (Fig. 53).

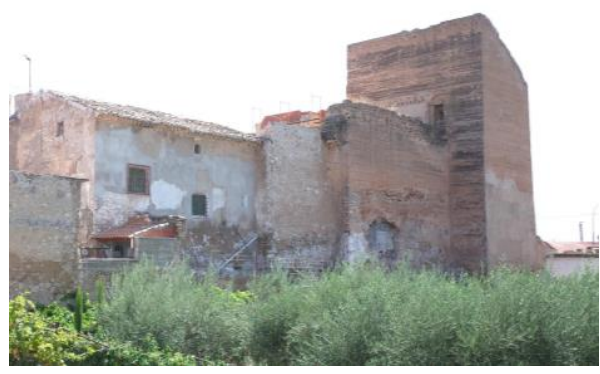

Fig. 53. Isso. Barrio de la fortaleza. Vista de su frente occidental. A la derecha, la torre de esquina suroeste.

La pervivencia de aspectos culturales asociados a una tradición constructiva relacionada con el entorno y sus recursos, hizo que las nuevas edificaciones se basaran en el uso de la tierra y el empleo, ininterrumpido, de la tapiería, junto con la madera, el yeso y, excepcionalmente, la cerámica. Las nuevas casas, última etapa en la evolución de la fortaleza, no la redujeron a la condición de despojo sino que escribieron una nueva página de su historia, con toda la riqueza de una cultura popular que, aunque en declive, mantiene una débil llama en los hogares que, apenas, subsisten (Fig. 54).

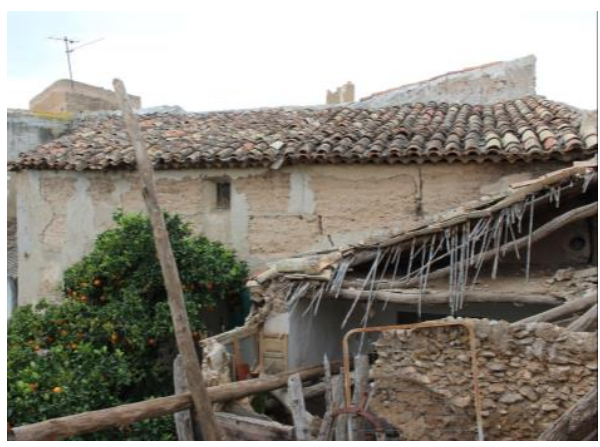

Fig. 54. Isso. Barrio de la fortaleza. Vista desde el este de una de las casas (parcela $n^{\circ} 4$ ) construidas en el interior de la fortaleza. Sus muros son de tapia muy terrosa.

\section{Conclusiones}

Hasta el momento de comenzar la investigación, solo se sabía de la existencia de las dos torres contiguas y el comienzo de los dos muros adosados a ellas; del resto de la fortaleza todo se ignoraba, aparte de alguna vaga noticia de la existencia de muros antiguos en alguna vivienda de las que componen la manzana del castillo (Simón, 2011, pp. 196-198). Es por este conocimiento parcial que se tenía que popularmente ni siquiera era identificado como un castillo, sino que se le denominaba como la Torre de Isso.

Gracias a los trabajos exhaustivos de arqueología de la arquitectura, llevados a cabo en todas y cada una de las viviendas y solares que componen la manzana, ahora sabemos que, en realidad, esos restos no son sino la cuarta parte de una fortaleza de dimensiones mucho mayores, de planta aproximadamente cuadrangular con unos $44 \mathrm{~m}$ de lado, con torreones en las esquinas y con otros menores situados en el centro de, al menos, tres de sus lados. A pesar de que hemos conseguido identificar, en buena medida, el perímetro del edificio, quedan por definir algunos puntos y aclarar determinadas 
cuestiones importantes, como todo lo relacionado con el acceso o accesos, la disposición exacta del frente oriental, así como la relación con el castillo de un aljibe situado fuera de su perímetro.

Otro de los avances que hemos logrado en el transcurso de esta campaña ha sido llegar a saber que la fortaleza no se levantó en un único momento, sino que, al menos, hubo dos fases constructivas bien diferenciadas: la más antigua a base de basamentos de calicanto y alzados de tapiería calicostrada, y la más reciente compuesta por tapias de hormigón. Esta última podría coincidir en buena medida con las dos torres y con los lienzos de muralla a ellas asociados. También se ha detectado, especialmente con motivo de las intervenciones arqueológicas realizadas en el frente septentrional, la existencia de una fase tardía, consistente, básicamente, en el forro de las fábricas originales mediante obra de tapia de hormigón. No hay conexión entre estas reformas y la construcción de las dos torres y los lienzos asociados del ángulo sudoccidental del castillo, por lo que no sabemos si ambas corresponden a un mismo momento o no. Por tanto, después de la construcción original hay evidencias de varias reformas en el perímetro del castillo, las más importantes son las dos comentadas, pero no sabemos si ambas reflejan dos momentos constructivos diferentes o si se trata del mismo.

En cuanto a la cronología de las fases del castillo y, lógicamente, a su interpretación histórica, también hemos logrado avances, aunque persisten dudas importantes.

Sabemos, en líneas generales, que las dos o tres etapas han de situarse entre los siglos XII y XIV, aunque no podemos afinar mucho más por falta de datos, y esto es importante porque de ello depende la adscripción de cada una de ellas a época andalusí o cristiana. Se han tomado muestras para análisis de Carbono 14 de maderas y hueso procedentes de la torre del ángulo suroeste, que sería en principio de la fase más tardía, y hasta el momento contamos con tres dataciones: 2 de ellas (maderas) ofrecen una fecha de entre 1090-1250 y la tercera (hueso) de 1270-1390. Por consiguiente, y a falta de que se nos faciliten los resultados de los análisis del resto de las muestras que son la mayoría, esta aproximación a la cronología absoluta del edificio no está proporcionando resultados concluyentes.

Técnicamente, el empleo del tapial para fabricar muros de hormigón se desarrolló durante toda la Edad Media a partir de finales del siglo $\mathrm{XI}$ sin cambios significativos, por lo que el análisis de la técnica constructiva no nos facilita avanzar en este sentido. En época tardoandalusí, las fortalezas levantadas por el Estado y las edificadas por las comunidades locales para su autodefensa acostumbran a presentar diferencias constructivas. A partir de época almorávide, las primeras son obras que presentan sólidas tapias de hormigón en los basamentos y zócalos mientras que el resto del alzado se hace con tapias de tierra calicostrada: este es, por ejemplo, el caso de las fortalezas y almunias edificadas por Ibn Mardanīš en Monteagudo a mediados del siglo XII. Durante esos mismos años, las fortalezas levantadas en los hușūn del medio rural estaban generalmente constituidas por basamentos de mampostería tomada con mortero bastardo y alzados de tierra, como se puede comprobar en las alcazabas de Siyāsa (Cieza) o Sierra (Tobarra). No obstante, también consta la existencia de fortalezas campesinas construidas con tapial desde su arranque, en estos casos no cambia la técnica fundamental, pero sí los materiales constituyentes de las tapias, como por ejemplo el castillo del Río de Aspe (Alicante) o el de Alpera (Albacete). Por consiguiente, si el castillo de Isso primigenio fuera andalusí, desde el punto de vista técnico podría ser una obra construida tanto por iniciativa estatal como por la comunidad campesina.

Cabría también la posibilidad de que se tratara de un castillo construido inmediatamente después de la conquista. En este caso, podría ser una fortaleza-residencia señorial, aunque las dimensiones parecen a todas luces excesivas para este propósito; o bien, podría tratarse del recinto fortificado de una puebla o pequeño concejo cristiano de nueva creación, del tipo que encontramos en poblaciones relativamente próximas como Socovos o Taibilla (Navarro, 
Jiménez, 2009, pp. 734-737).

El análisis territorial nos ha permitido aproximarnos a las peculiaridades del poblamiento del término de Isso en la Edad Media, algo fundamental para interpretar adecuadamente la propia fortaleza, de acuerdo con las hipótesis planteadas previamente. Gracias a ello, sabemos que el pequeño núcleo habitado en torno al castillo se ha servido tradicionalmente de la fuente situada $3 \mathrm{~km}$ al norte de la población actual. Este manantial se dividía mediante partidores de los que arrancaban acequias que irrigaban los pagos asociados a pequeñas aldeas o "barrios" que jalonan el territorio en un número en torno a las tres decenas. Otras fuentes como la Pestosa, la del Hilo de Polope y la de las Mercedes, beneficiaban los heredamientos de otras alquerías, conformando así un poblamiento relativamente intenso, aunque disperso, que podría explicar la monumentalidad de la fortaleza objeto de este trabajo, de tamaño y extensión demasiado considerables si solo estuviera en relación con el caserío que la circunda.

A la luz de la información arqueológica de que actualmente disponemos del castillo de Isso y de las prospecciones de su territorio, así como del análisis de los modelos que se han podido estudiar en el entorno, propondremos una hipótesis acerca de su evolución histórica. El poblamiento disperso del territorio de Isso, a base de pequeñas alquerías o "barrios" que conocemos bien a partir de la documentación posterior a la conquista cristiana, creemos que estaba condicionado por la geografía del término, dividido en vallejos y pequeñas vegas paralelas que se extendían de norte a sur, por los que circulaban las aguas de varias fuentes, esta disposición del territorio creemos que también determinó el patrón de poblamiento en época andalusí. Junto a la vega más importante se situaría la alquería mayor, en torno a una muela que facilitaba su defensa y la de los otros núcleos menores del territorio. Quizás también aquí se situaba un oratorio que, seguramente, también daba servicio como mezquita aljama rural a todas las alquerías. En cualquier caso, es necesario reconocer que, en el estado actual del conocimiento, no existe evidencia arqueo- lógica alguna de esta alquería andalusí asociada a la fortaleza.

No obstante, el modelo de poblamiento que proponemos para Isso está bien documentado en época andalusí, con ciertas variantes, en otros territorios, como por ejemplo las vegas de Murcia y Granada, Finestrat (Alicante) o Puentes (Lorca) y, más cerca de Hellín, en Alpera (Albacete). En este último lugar también existe una organización similar en la ocupación del territorio, aunque con la diferencia de que en este caso estamos ante un solo espacio hidráulico y no ante la aparente división segmentaria de Isso, que está jerarquizada en un sistema principal y otros secundarios que lo complementan. Se trata, en definitiva, de un tipo de poblamiento compuesto por pequeñas alquerías dispersas entre las que no existe una gran diferencia de tamaño, si bien alguna de ellas adquiere un cierto rango preponderante por la presencia de establecimientos colectivos como la fortaleza o la mezquita aljama; un modelo que contrasta con el de los grandes huușūn, como por ejemplo Siyāsa o Chinchilla por ceñirnos al entorno estudiado, que concentran la población de su territorio creando un vacío de alquerías en torno a ellos.

Siguiendo con las analogías, en el asentamiento central de Alpera existía una muela que fue fortificada con lienzos y torreones de tapiería de hormigón en época tardoandalusí, según demuestran los abundantes materiales cerámi$\cos$, y posteriormente ocupada y reacondicionada tras la conquista (Simón, 2011, pp. 117120). Al igual que en Alpera, creemos que también en Isso existiría una fortificación andalusí para protección de los pobladores del área circundante, que seguramente adaptaría su plano al perímetro natural del promontorio. Sabemos por los textos que el territorio de Alpera, con su castillo central, sus alquerías y su vega, no era un hiṣn independiente, sino que formaba parte en época almohade del iqlìm o término del hiṣn de Almansa, aunque era reconocido como una realidad territorial individualizada que, de hecho, acabó convirtiéndose en señorío. En el caso de Isso, no contamos con datos en las fuentes escritas que nos informen acerca de su condición en época andalusí, aun- 
que dada la naturaleza de su disposición territorial y su carácter señorial en el periodo castellano, nos parece que es sensato plantear la hipótesis de que estemos ante un caso análogo al de Alpera, es decir, que antes de la conquista constituyera una unidad territorial y administrativa compuesta por castillo y alquerías en torno al mismo, que pudo depender de alguno de los husụūn más próximos, como Hellín o Tobarra, o incluso ser autónoma.

Es posible que la fortaleza se remodelara inmediatamente después de la conquista cristiana, y que fuera en ese momento cuando adquirió la regularidad y monumentalidad de la planta que hemos podido documentar, dado que entonces se desarrollaron unas necesidades de representación y propaganda edilicia que no existieron en época andalusí cuando la función de la fortificación sería esencialmente práctica. También es probable, como antes comentábamos, que en este momento temprano de la dominación castellana estemos más bien ante el recinto de una pequeña puebla de repobladores que ante un castillo señorial. Se trata, en definitiva, de hipótesis de trabajo que sólo podrán confirmarse, rebatirse o matizarse, con el desarrollo de los trabajos que aún continúan en marcha, la obtención de un mayor número de datos a partir de los análisis arqueométrico, y futuras intervenciones arqueológicas.

En Isso, a partir de un enclave natural que posibilita la vida, el hombre ha ido formando una compleja estratificación de estructuras arquitectónicas que se han sucedido mediante la reutilización, la reforma, la destrucción, o el añadido de nuevas construcciones que, limadas por el paso del tiempo, han llegado a nuestros días parcialmente habitadas. Ese continuo y sus rupturas conforman la auténtica memoria del lugar. La conservación de toda esa experiencia humana constituye nuestra mayor responsabilidad y el reto más importante. Es necesario preservar todos los testimonios materiales de lo que allí sucedió. Para ello, consideramos que todas las etapas históricas deben ser tenidas en cuenta y recuperadas, pues tan valiosa es la fortaleza original como sus transformaciones o las casas que se le adosaron a partir del siglo XVI. El mayor desafío que puede tener este proyecto radica en proteger y conservar todos los valores patrimoniales que tiene la manzana de la fortaleza y las huertas anexas, a la vez que es necesario rehabilitar las casas y recuperar la población perdida.

\section{Notas}

${ }^{1}$ Este trabajo de investigación ha sido financiado por dos administraciones públicas: Junta de Castilla-La Mancha, Viceconsejería de Cultura, a través del proyecto de investigación La torre de Isso (Hellín, Albacete): caracterización constructiva y poblamiento medieval asociado, expediente SBPLY/19/ 180801/000030; Ayuntamiento de Hellín, a través del contrato de investigación Estudio histórico arqueológico y arquitectónico del Castillo de Isso, expediente $106117 \mathrm{~K}$. Se ha realizado en el marco del proyecto ALMEDIMED “Almunias medievales en el Mediterráneo: Historia y conservación de los paisajes culturales periurbanos" (PID2019-111508GBI00), del que es IP el Dr. Julio Navarro (EEA-CSIC). Cofinanciado con fondos FEDER, pertenece al Programa Estatal de Generación de Conocimiento y Fortalecimiento Científico y Tecnológico del Sistema de $\mathrm{I}+\mathrm{D}+\mathrm{i}$, Subprograma Estatal de Generación del Conocimiento, del Ministerio de Ciencia e Innovación.

${ }^{2}$ Queremos mostrar nuestro agradecimiento a Beatriz Esteban Muñecas, responsable del Archivo Histórico Municipal de Hellín por su inestimable ayuda en el proceso de búsqueda de documentación relativa a Isso.

${ }^{3}$ La documentación gráfica que aparece en este trabajo se ha desarrollado a partir de una intensa labor de levantamiento fotogramétrico y arquitectónico, que ha sido realizada por Anne Claire Bled y Sara Peñalver, con la colaboración de Laura Correa y Felipe Villegas. Por su parte, Miguel Garrido ha sido el responsable de la producción de infografías.

${ }^{4}$ Biblioteca virtual de Defensa [Ar. G-T.4-C.4-201]. Archivo Cartográfico de Estudios Geográficos del Centro Geográfico del Ejército - Colección: SG Signatura: Ar. G-T.4-C.4-201.

${ }^{5}$ Archivo General de Simancas. Dirección General de Rentas, $1^{\text {a }}$ Remesa. Catastro de Ensenada. Respuestas Generales. L. 463.

${ }^{6}$ Archivo de Simancas. R.G.S. IV-1494. "Sobre la conservación de las acequias de riego". Transcripción, con actualización ortográfica, realizada por Beatriz Esteban Muñecas. 
${ }^{7}$ Expediente para el nombramiento de una junta que entienda en el arreglo y desenvoltura de las aguas de la fuente de Yso. 1860. Archivo histórico municipal de Hellín. Signatura: A_00474_005.

${ }^{8}$ Ordenanzas de la Comunidad de Regantes de la Acequia de Isso (Hellín), artículo $1^{\circ}$.

${ }^{9}$ Plano topográfico a escala 1:25.000, hoja B-1 (provincia de Albacete, ayuntamiento de Hellín), realizado en 1878 y actualizado en tres ocasiones: 1921, 1951 y 1965. Procedente del Archivo Topográfico del Instituto Geográfico Nacional.

${ }^{10}$ Diario de Madrid, 9 de septiembre de 1819, pp. 350-351.

${ }^{11}$ Sobre esta fortaleza desaparecida en gran medida, contamos con una descripción realizada en 1592 (Diligencias efectuadas por los Corregidores de distintos lugares sobre el estado de sus fortalezas y casas fuertes. Archivo General de Simancas. CCA, DIV, 26,1 .

${ }^{12}$ Estructuralmente sólo dispone un arco de tipo escarzano construido con sillares de piedra arenisca de color amarillo. Tiene una luz de $3 \mathrm{~m}$ siendo su altura de $2 \mathrm{~m}$ y la anchura de su bóveda de unos $5,5 \mathrm{~m}$ (Barquero, et al., 1983, pp. 57-58).
${ }^{13}$ La tapia de este huerto delimita un gran espacio irregular que desborda la trasera de la casa para invadir la de la iglesia y las de los primeros huertos que hay al este del templo. Si observamos con detalle la fotografía aérea se pueden ver algunos indicios de una conformación más antigua en la que la planta del huerto, además de tener unas dimensiones más reducidas, era más regular, con tendencia a formar un rectángulo, cuya anchura sería la proyección de la que tiene la gran vivienda. A esta primera conformación del huerto corresponden la estructura de crucero y los elementos arquitectónicos que lo enriquecían a modo de jardín. Podemos concluir afirmando que el primitivo crucero tuvo unas dimensiones de casi 70 $\mathrm{m}$ de largo por $54 \mathrm{~m}$ de ancho, y que fue ampliado hacia el este. Un huerto de similares características aunque menor lo analizaremos más adelante al estudiar la agrupación de viviendas $\mathrm{n}^{\mathrm{0}} 3$.

${ }^{14}$ Este huerto tiene unas dimensiones más reducidas $(33 \times 27 \mathrm{~m})$ que el existente en la agrupación de casas $\mathrm{n}^{\circ}$ 2. Se sitúa al norte, al otro lado de la tapia, fuera de los límites de los antiguos huertos traseros de las casas; lamentablemente desconocemos las características de la casa a la que estuvo asociado.

\section{Agradecimientos}

Este trabajo no se hubiera podido llevar a cabo sin la cooperación de un nutrido grupo de personas que, de una u otra forma, nos han ayudado a entender y documentar el territorio de Isso y su fortaleza. En primer lugar mencionaremos a los colegas que más estrechamente han participado en las tareas de campo y en la revisión del texto que ahora se publica: José Ignacio Barrera, Anne-Claire Bled, Pablo Cercós, Juan Antonio García, Juan Jordán, Francisco Javier López Precioso, Bárbara Muñoz, Jonathan Ruiz, José Luis Simón y Maurizio Toscano. Es de justicia destacar la especial colaboración del bibliotecario de Isso, Vicente Sagredo, pues sin sus conocimientos y continuo asesoramiento este trabajo no hubiera salido a la luz. Nuestro reconocimiento va dirigido también al acequiero, a los molineros, a los dueños de las viviendas y, en general, a todos los vecinos de Isso por su generosidad al facilitarnos el acceso a sus propiedades. No podemos dejar de valorar el apoyo que hemos recibido de todos los miembros de la corporación municipal, en particular el de su alcalde, Ramón García, y el del concejal de Patrimonio Histórico, Juan Antonio Andújar, así como la ayuda recibida de la alcaldesa (pedánea) Cristina Valcárcel. Queremos concluir, siguiendo el consejo evangélico de que los "últimos serán los primeros", reconociendo a María Jesús López, concejal de Turismo, como indiscutible alma máter del proyecto. A todos los mencionados y a los que por olvido no hemos citado les expresamos públicamente nuestra gratitud. 


\section{Bibliography}

Abascal Palazón, J.M.; Die Maculet, R.; Cebrian Fernández, R. (2009). Antonio Valcárcel Pío de Saboya, Conde de Lumiares (1748-1808): apuntes biográficos y escritos inéditos, Antiquaria Hispánica, Real Academia de la Historia, Alicante.

Abascal Palazón, J.M.; Abad Casal, L. (2013). "El descubrimiento y recuperación del sarcófago romano de Hellín. Una aventura arqueológica decimonónica", in Cid López, R.M.; García Fernández, E., eds., Debita verba: estudios en homenaje al profesor Julio Mangas Manjarrés, Ed. Universidad de Oviedo, Oviedo, pp. 45-62.

Alcalde Guindo, C. (2008). Censo de pecheros de Carlos I, 1528, Edición basada en la documentación del Archivo de Simancas, sección de Contadurías Generales, legajo nº 768, Madrid.

Almagro Costa, F.J. (2013). Memoria de los trabajos de medida de caudales en manantiales y niveles hidrométricos y piezométricos en humedales de la Cuenca del Segura, Ministerio de Agricultura, Alimentación y Medio Ambiente, Confederación Hidrográfica del Segura.

Amador de los Ríos, R. (1912). Catálogo de los Monumentos Históricos y Artísticos de la provincia de Albacete, vol 1. Edición Facsímil. Carrión, V.P.; Sánchez, J. (2005). Albacete.

Aragón Rueda, R. (2010). Identificación y caracterización de la interrelación que se presenta entre aguas subterráneas, cursos fluviales, descarga por manantiales, zonas húmedas y otros ecosistemas naturales de especial interés hídrico. 071.004 Boquerón. Demarcación Hidrográfica 071. Segura, Instituto Geológico y Minero de España. Dirección General del Agua, pp. 1-7.

Ayllón Gutiérrez, C. (2015). Iglesia rural y sociedad en la Edad Media (Alcaraz y Señorio de Villena), Silex D.L., Madrid.

Ayllón Gutiérrez, C. (2017). "El señorío y la propiedad de Ontur y Albatana al hilo de los acontecimientos históricos", Estudios sobre patrimonio, cultura y ciencias medievales, 19, pp. 105-132.

Ballesteros Linares, M. (2004). "Un documento clarificador de la encomienda de Segura de la Sierra. Liétor. 1435", Boletín del Instituto de Estudios Giennenses, 188, pp. 179-222.

Baquero Aguilar J.J.; Martínez Cano, J.C.; Jordán Montés J.F. (1983). “Los puentes romanos de Isso (Hellín)”, AlBasit, 12, pp. 47-88.

Blanch e Illá, N. (1866). Crónica de la provincia de Albacete, Eds. Ronchi y compañía, Madrid.

Carmona, A. (2009). "El sur de Albacete y los emplazamientos de Iyuh", Al- Basit, 54, pp. 5-27.

Carmona A.; Giménez, A. (2008). Carta de Compraventa otorgada por el moro Aboaballa, hijo del alcayat de Albacete, de la aldea de Sierra, junto a Hellin y Tobarra, que el rey le concedió, a favor del concejo de Alcaraz. Jerez, 6 de marzo, 1268, Colección documental albacetense, 3, Instituto de Estudios Albacetenses "Don Juan Manuel", Diputación de Albacete, Albacete.

Carrilero Martínez, R. (2000). Carlos V y Albacete. Colección documental del emperador en el Archivo HIstórico Provincial, Instituto de Estudios Albacetenses "Don Juan Manuel”, Diputación Provincial de Albacete, Albacete.

Carrilero Martínez, R.; García Moratalla, P.J.; Cifo González, M.; Vandelvira González, G. (2014). Pueblos de la provincia de Albacete en las Relaciones Topográficas de Felipe II (Estudio documental, filológico e histórico), Instituto de Estudios Albacetenses "Don Juan Manuel", Albacete.

Ceán- Bermúdez, J. A. (1832). Sumario de las antigüedades romanas que hay en España, Imprenta de Miguel de Burgos, Madrid.

Cebrián Abellán, A.; Cano Valero, J. (1992). Relaciones topográficas de los pueblos del reino de Murcia, EDITUM, Murcia.

Díaz Cassou, P. (1895). Serie de los obispos de Cartagena, Madrid.

Doménech Belda, C.; Gutiérrez Lloret, S. (2006). "Viejas y nuevas monedas en la ciudad emiral de madinat iyyuh (El Tolmo de Minateda, Hellín, Albacete)", Al-Qantara, 27 (2), pp. 337-374.

Espinalt García, B. (1778). Atlante Español. Descripción general de todo el Reino de España, Reino de Murcia, Madrid. Edición facsímil. (1980). Academia Alfonso X El Sabio, Murcia.

Esteban Muñecas, B.; Martínez Jiménez, J. (2019). "La parroquial de Isso (Hellín)”, El Faro de Hellín, 16 de febrero, p. 22. 
Franco Sánchez, F. (1995). Vias y defensas andalusies en la Mancha Oriental, Diputación Provincial de Alicante, Alicante.

Gamo Parras, B. (1998). La Antigüedad Tardía en la provincia de Albacete, Instituto de Estudios Albacetenses, Diputación de Albacete, Albacete.

García Atienza, G.; López Precioso, F.J. (2010). El yacimiento de Fuente de Isso y el poblamiento neolítico en el campo de Hellin (Albacete), Instituto de Estudios Albacetenses, Albacete.

González Arce, J.D. (2008). "La fiscalidad agraria en el Señorío de Villena en la Baja Edad Media", in Vallejo Pousada, R., ed., Los tributos de la tierra. Fiscalidad y agricultura en España (siglos XII- XX), Universitat de València, Valencia, pp. 93-126.

González Fernández, R.; González Blanco, A.; Amante Sánchez, M. (1993). "Los graffiti más recientes de la cueva de La Camareta", Antigüedad y cristianismo, 10 (Ejemplar dedicado a: La cueva de la Camareta (Agramón, Hellín-Albacete), pp. 379-432.

González Jiménez, M.; Molina Molina, A.L. (2008). Los milagros romanzados de Santo Domingo de Silos de Pero Marín, Real Academia de Alfonso X el Sabio, Murcia.

Gutiérrez Lloret, S. (1996). La Cora de Tudmir, de la antigüedad tardia al mundo islámico, Casa de Velázquez, Madrid-Alicante.

Gutiérrez Lloret, S. (2011). "El Tolmo de Minateda en torno al 711”, in García Moreno, L.A.; Vigil-Escalera, A., cords., 711. Arqueología e historia entre dos mundos, vol 1., Museo Arqueológico Regional de Madrid, Madrid, pp. 353-372.

Hinojosa Montalvo, J. (1987). "El marquesado de Villena. Frontera con el reino de Valencia", in Actas del Congreso de Historia del Señorio de Villena, Albacete, 23-26 de octubre de 1986, Instituto de Estudios Albacetenses "Don Juan Manuel", Albacete, pp. 227-233.

Irigoyen López, A; García Olmo, M.A.; García Hourcade, J.J. (2002). “Albacete en los documentos episcopales durante la Edad Moderna”, in Santamaría Conde, A.; García-Saúco Beléndez, L.G.; Sánchez Ferrer, J., coords., II Congreso de Historia de Albacete, vol. 3 (Edad Moderna), Instituto de Estudios Albacetenses "Don Juan Manuel", Albacete, pp. 217-225.

Jiménez Castillo, P.; Simón García, J.L. (2017). "El poblamiento andalusí en las tierras de secano: el área sudoriental de la Mancha (ss. XI-XIII)”, Al-Qantara, 38, pp. 215-259.

Jiménez Lorente, S.; Jordán Montes, J.; Ayala Juan, Ma .M. (1995). "El taller de la ermita del Pedernaloso (Hellín, Albacete): nuevas aportaciones al estudio de los talleres de sílex al aire libre”, Anales de Prehistoria y Arqueología, 11-12, pp. 17-22.

Jordán Montes, J.F.; González Blanco, A. (1985). "Probable aportación al monacato del SE peninsular: el conjunto rupestre de la Muela de Alborajico", Antigüedad y cristianismo, 2 (Ejemplar dedicado a: Del Conventus Carthaginensis a la Chora de Tudmir, Perspectivas de la Historia de Murcia entre los siglos III-VIII), pp. 335 364.

Jordán Montés, J.F. (1987). "Las ermitas de la comarca de Hellín - Tobarra. Ejemplo de cristianización de espacios sacros", in IV Jornadas de etnología de Castilla La Mancha, Toledo, pp. 411- 437.

Jordán Montés, J.F. (1992). "Prospección arqueológica en la comarca de Hellín-Tobarra: (metodología, resultados y bibliografia)”, Al-Basit, 31, pp. 183-227.

Jordán Montes, J.F.; Monge Llor, M. (1993). "Planimetría y perspectivas tridimensionales del eremitorio rupestre hispanovisigodo de Alborajico (Tobarra, Albacete)", Antigüedad y cristianismo, 10 (Ejemplar dedicado a: La cueva de la Camareta (Agramón, Hellín-Albacete), pp. 497-506.

Laredo y Nahón, A.I. (1978). Les noms des Juifs du Maroc. Essai d'onomastique Judeo-Marocaine, CSIC, Madrid.

López Fernández M. (2004). "Las incursiones sobre las sierras albaceteñas en otoño de 1241 y primavera de 1242”, Al-Basit, 48, pp. 33-51.

López Martínez, F.J. (1999). “Tapias y tapiales”, Loggia, 8, Universidad Politécnica de Valencia, pp. 74-89.

López Montoya, R. (2002). “Arquitectura popular cucos y chozos en la comarca de Hellín”, Al-Basit, 46, pp. 229248.

López Precioso, F.J.; Jordán Montes, J.F.; Soria Combadiera, L. (1992). “Asentamientos ibéricos en el Campo de Hellín: su relación con el trazado viario y la red comercial”, Verdolay, 4, pp. 51-62. 
López Precioso, F.J. (1993). "Vías romanas y visigodas en el campo de Hellín”, Antigüedad y Cristianismo, 10, pp. 93-131.

López Serrano, A. (2017). "Conquista y ocupación de Hellín, Tobarra, Albatana y Ontur", Estudios sobre patrimonio, Cultura y Ciencias Medievales, 19, pp. 783-824.

Losada Azorín, A.A. (1986). "El clima del municipio de Hellín”, I Reunión de Estudios Regionales de Castilla - La Mancha, vol. III, pp. 127-144.

Losada Azorín, A.A. (1997). "Las Murallas de la ciudad de Hellín”, Cuadernos de Historia, 6, Asociación Cultural Amigos de Hellín, Hellín.

Losada Azorín, A.A. (1999). Historia de Isso, Ed. La Actualidad, Hellín.

Losada Azorín, A.A. (2003). El castillo de Hellín: su evolución y estructura urbana, Asociación Cultural Amigos de Hellín, Hellín.

Losada Azorín, A.A. (2006). La reconquista de Hellín y el origen del culto a la Virgen del Rosario (1266-2006), Hellín.

Lozano y Santa, J. (1794). Bastitania y Contestania del Reino de Murcia con los vestigios de sus ciudades subterráneas, Manuel Muñiz, Murcia.

Madoz, P. (1847). Diccionario geográfico-estadístico-histórico de España y sus posesiones de ultramar, vol. 9 , Madrid.

Martínez Carrillo, Ma L1. (1991). "Historicidad de los “Miraculos Romançados” de Pedro Marín (1232-1293). El territorio y la esclavitud granadinos", Anuario de Estudios Medievales, 21, pp. 69-96.

Mateo Guerrero, R. (1833). Proyecto de Ordenanzas de Campo y Huerta del Término municipal de Hellín, Hellín.

Miñano, S. (1826). Diccionario geográfico-estadístico de España y Portugal, Madrid.

Miñano, S. (1829). Diccionario geográfico-estadístico de España y Portugal. Suplemento, Madrid.

Molina López, E. (1971). "Iyyu(h): otra ciudad yerma hispanomusulmana”, Cuadernos de Historia del Islam, 3, pp. 67-82.

Molina López, E. (1972). La Cora de Tudmir según Al-Udri (s. XI): aportaciones al estudio geográfico descriptivo del sureste peninsular, Publicaciones del Seminario de Historia del islam de la Universidad de Granada, Granada.

Molina Molina, A.L. (2015). "Episodios en las relaciones fronterizas entre los reinos de Murcia y Granada (siglos XIII-XV): Los cautivos murcianos en «tierra de moros» y su liberación”, Revista del CEHGR, 27, pp. 145-165.

Molina Puche, S. (2005). "El gobierno de un territorio de frontera. Corregimiento y corregidores de Chinchilla, Villena y las Nueve Villas: 1586-1690”, Investigaciones históricas, Época Moderna y Contemporánea, 25, pp. $55-84$.

Moreno García, A. (1993). "Sobre las inscripciones modernas de la cueva de La Camareta", Antigüedad y cristianismo, 10 (Ejemplar dedicado a la cueva de la Camareta (Agramón, Hellín-Albacete), pp. 449-451.

Navarro Palazón, J.; Jiménez Castillo, P. (2009). "El poblamiento andalusí tras la conquista castellana”, Catálogo de la exposición “Alfonso X el Sabio”, Murcia, pp. 726-739.

Nieto Vidal, P. (2011). Memoria de intervención para la consolidación de las pinturas y grafitos de la Torre de Isso-Hellín (Albacete), El Parteluz Restauraciones y Rehabilitaciones, S. L., (inédito).

Nipho y Cagigal, F.M. (1770). Correo general de España, Madrid, vol. 1.

Peset Reig, M. (1984). "Los fueros de la frontera de Albacete: una interpretación histórica", Congreso de Historia de Albacete, 11, pp. 31-48.

Pocklington, R. (1988). "El emplazamiento de lyyi(h)”, Sharq Al-Andalus, Estudios Árabes, 4, pp. 175-198.

Pocklington, R. (2010). “Toponimia ibérica, latina y árabe de la provincia de Albacete”, Al-Basit, Revista de Estudios Albacetenses, 55, pp. 11-167.

Pretel Marín, A.; Rodríguez Llopis, M. (1998). El señorio de Villena en el siglo XIV, Instituto de Estudios Albacetenses “Don Juan Manuel”, Albacete.

Pretel Marín, A. (1981). "Algunas acciones militares de Albacete y su comarca en las luchas de los Infantes de Aragón (1421-1444)”, Al-Basit, 10, pp. 5-72. 
Pretel Marín, A. (1982). Don Juan Manuel, señor de la llanura: población y gobierno de la Mancha albacetense en la primera mitad del siglo XIV, Instituto de Estudios Albacetenses, Albacete.

Pretel Marín, A. (1983). "Las tierras albacetenses en la política castellana de mediados del siglo XV (1448-1453)", Anales del Centro Asociado de la UNED de Albacete, 5, pp. 347-428.

Pretel Marín, A. (1986). Conquista y primeros intentos de repoblación del territorio albacetense (del periodo islámico a la crisis del siglo XIII), Instituto de Estudios Albacetenses “Don Juan Manuel”, Albacete.

Pretel Marín, A. (1998). Hellín Medieval, Instituto de Estudios Albacetenses “Don Juan Manuel”, Diputación de Albacete, Albacete.

Pretel Marín, A.; Rodríguez Llopis, M. (1998). El Señorio de Villena en el siglo XIV, Instituto de Estudios Albacetenses "Don Juan Manuel”, Diputación de Albacete, Albacete.

Pretel Marín, A. (2000). "Iglesia, religión y religiosidad en la Baja Edad Media Albacetense", Al-Basit, 44, pp. 45109.

Pretel Marín, A. (2008). Alcaraz y su tierra en el siglo XIII, Instituto de Estudios Albacetenses "Don Juan Manuel”, Diputación de Albacete, Albacete.

Retuerce Velasco, M. (1995). “Arqueología y poblamiento en la meseta andalusí. El Referente cerámico”, in Iglesia Duarte, J.I de la, coord., V Semana de estudios medievales: Nájera, 1 al 15 de agosto de 1994, Instituto de Estudios Riojanos, Logroño, pp. 87-124.

Roa Erostarbe, J. (1894). Crónica de la provincia de Albacete, Albacete.

Rodríguez Llopis, M. (1984). "Expansión agraria y control de pastos en tierras albacetenses durante el siglo XV", Congreso de Historia de Albacete, Instituto de Estudios Albacetenses “Don Juan Manuel”, Albacete, pp. 155 180.

Rodríguez Llopis, M. (1986). "La población albacetense al comienzo del siglo XVI”, Información Cultural Albacete, 7, pp. 1-16.

Rodríguez de la Torre, F. (1985). Albacete en textos geográficos anteriores a la creación de la provincia, Instituto de Estudios Albacetenses, CSIC, Confederación Española de Centros de Estudios Locales, Albacete.

Rodríguez de la Torre, F.; Cano Valero, J. (1987). Relaciones geográfico- históricas de Albacete (1786-1789) de Tomás López, Instituto de Estudios Albacetenses “Don Juan Manuel”, Diputación de Albacete, Albacete.

Sánchez Ferrer, J.; Navarro Pretel, F.; Collados Reolid, J.P. (2006). "Las imágenes del convento carmelita de Liétor en 1835", Al-Basit, 50, pp. 275-332.

Sanz Gamo, R. (1997). Cultura Ibérica y Romanización en tierras de Albacete: los siglos de transición, Instituto de Estudios Albacetenses “Don Juan Manuel”, Albacete.

Sanz Gamo, R. (2016). "Noticias e intervenciones en la villa romana de Hellín (Albacete)", Boletín del Museo Arqueológico Nacional, 34, pp. 155-166.

Selva Iniesta, A.; Jordán Montés, J.F. (1988). "Notas sobre la red viaria romana en la comarca de Hellín - Tobarra (Albacete)", in González Blanco, A., coord., Vias romanas del sureste: Actas del symposium celebrado en Murcia, 23 a 24 octubre, 1986, Universidad de Murcia, Murcia, pp. 85-100.

Selva Iniesta, A. (1993). "La encantada de La Camareta. Antología e interpretación. (Revisión del tema)", Antigüedad y cristianismo, 10 (Ejemplar dedicado a la cueva de la Camareta (Agramón, Hellín-Albacete), pp. 479-485.

Serra Martínez, J. (1952). "Fundación en Hellín del Convento de Santa Clara”, Macanaz, 2, pp. 17-19.

Simón García, J.L. (2011). Castillos y torres de la provincia de Albacete, Instituto de estudios albacetenses "Don Juan Manuel", Diputación de Albacete, Albacete

Torres Fontes, J. (1969). Colección de documentos para la historia del Reino de Murcia, Documentos del siglo XIII, Murcia, vol. II.

Torres Fontes, J.; Molina Molina, A.L. (2009). Fundamento de la Santa Iglesia y de toda su Diócesis de Carthagena, escrito, y ordenado por el Ilustrísimo Señor Don Diego Comontes, Edición de la Real Academia de Alfonso X el Sabio, Murcia. 